\title{
An application-oriented roadmap to select polymeric nanocomposites for advanced applications: A review
}

Doagou-Rad, Saeed; Islam, Aminul; Merca, Timea D.

Published in:

Polymer Composites

Link to article, DOI:

$10.1002 /$ pc. 25461

Publication date:

2020

Document Version

Peer reviewed version

Link back to DTU Orbit

Citation (APA):

Doagou-Rad, S., Islam, A., \& Merca, T. D. (2020). An application-oriented roadmap to select polymeric nanocomposites for advanced applications: A review. Polymer Composites, 41(4), 1153-1189.

https://doi.org/10.1002/pc.25461

\section{General rights}

Copyright and moral rights for the publications made accessible in the public portal are retained by the authors and/or other copyright owners and it is a condition of accessing publications that users recognise and abide by the legal requirements associated with these rights.

- Users may download and print one copy of any publication from the public portal for the purpose of private study or research.

- You may not further distribute the material or use it for any profit-making activity or commercial gain

- You may freely distribute the URL identifying the publication in the public portal

If you believe that this document breaches copyright please contact us providing details, and we will remove access to the work immediately and investigate your claim. 


\title{
An application-oriented roadmap to select polymeric nanocomposites for advanced applications
}

\author{
Aminul Islam 1,2,*, Timea Denisa Merca ${ }^{2}$, Saeed Doagou-Rad 1,2 \\ ${ }^{1}$ Centre for Acoustic-Mechanical Microsystems (CAMM), Technical University of Denmark, \\ Building 352, DK-2800 Kgs. Lyngby, Denmark \\ ${ }^{2}$ Department of Mechanical Engineering, Technical University of Denmark, Produktionstorvet, \\ Building 427A, DK-2800 Kgs. Lyngby, Denmark
}

\begin{abstract}
Polymeric nanocomposites are the materials that incorporate nanosized particles or fibers into the polymer matrixes. The result of the addition of nanoparticles/fibers is a drastic improvement in properties that may include mechanical, electrical, thermal conductivity or even the acoustical properties of the materials. Polymer nanocomposites have spawned huge interest for the development of high-performance products such as lightweight sensors, windmill blades, thin-film capacitors, high performance batteries, flame retardant products, biodegradable and biocompatible materials suitable for areas ranging from packaging to biomedical applications, etc. The field of polymer nanocomposites has been at the forefront of research in the polymer community for the past few decades and an extremely large number of scientific papers have been published. Nevertheless an application oriented guidelines for selecting the ecofriendly nanocomposites for advanced industrial applications are missing in the state-of-the-art. This review paper summarizes the current state-ofthe-art polymeric nanocomposite highlighting prominent nanofillers categorized based on their applications, origins, dimensional characteristics, etc. Each filler type contains a short description of its main feature together with the most relevant and potential applications. To address the global concern about non-degradable wastes, novel green alternatives for each nanofiller type are discussed. Special attention is also given to the biocompatibility properties of the composites. This paper provides a state-of-the-art road map to select multifunctional polymeric nanocomposites from huge varieties for advanced industrial applications.
\end{abstract}

\section{Keywords: Nanocomposites, Nanofillers, Polymer, Biocompatibility}

\section{Introduction}

Polymer nanocomposites refer to polymer matrixes reinforced with fillers of different shape (e.g., platelets, fibers, spheroids, etc.) that contain at least one dimension in the range less than $100 \mathrm{~nm}$ [1]. As the result of comprising different materials, structures, and compositions in the nanocomposites, different properties suitable to various applications can be expected from them [2]. Therefore, multifunctional materials have been one of the main sources of interest for nanocomposite realm. The primal nanocomposites in late $19^{\text {th }}$ and early $20^{\text {th }}$ century such as carbon black, silica and, precipitated calcium carbonate etc. were recognized for their reinforcement capabilities [3]. The interest rose significantly from the 1950s when the first nanoclay composite was described in a patent from the National Lead Company of the USA. However a Toyota patent in 1988 on polyamide (PA) nanocomposites has initiated their wide-spread commercial applications in the industries [4]. The exponential growth of the polymeric nanocomposites owes to the discovery of an allotrope of carbon which is called C60 or Buckyball. This discovery paved the road for discovery of carbon nanotubes. Some of the most major improvements achieved from introduction of nanofillers into polymeric matrixes are: enhancement of mechanical properties [5]; improvements in thermal and electrical properties from the incorporation of carbon nanotubes [6], flame retardant properties in case of the introduction of nanoclays [7] and metal hydroxides [8], thermal stability, gas permeability, etc. The combination of carbon nanotubes (CNTs) has also raised significant interest in the development of shape memory materials due to the electrical properties of these nanocomposites [9]. Shape memory materials have the capability of being deformed into a temporary shape with the help of an external stimulus. The electrical properties of CNTs allow using electrical current to control smart actuators for many different applications. Moreover, the organic origins of some 
nanofillers such as nanocellulose, allow the usage of these materials for medical purposes due to their biocompatibility. With the advent of the concepts like the Cyber-Physical Systems, the Internet of Things, the Big Data, E-health monitoring etc. the demand for sensors, actuators, smart electronics, smart materials etc. will be drastically increased. So the polymer based nanocomposites can play ever bigger role in the future for advanced and specialized industrial applications.

A huge number of fundamental researches have been made on polymer based nanocomposites, but the applications of polymer based nanocomposites, application oriented selection of polymer based nanocomposites, eco-friendly selection of nanocomposites etc. are not adequately addressed by the state-ofthe-art literature. As application of polymeric nanocomposites is increasing in different industries, the interest of using these multifunctional materials as a viable alternative to traditional materials is soaring sharply. So, the aim of this review paper is to provide a guideline for the selection and application of some important nanomaterials and their corresponding composite materials. In order to provide a better overview of the progress in this field, nanomaterials and composites were categorized based on their geometrical characteristics and applications. Furthermore, green alternatives of the well-known nanocomposites have been introduced to reduce or eliminate the arising pollution from production and waste of the composite materials. Fig 1 categorise the important types of nanofillers and presents the subcategories of each type. Dimensional and shape characteristics are highlighted in different shades of grey; main application related properties of the nanofillers are highlighted in colored dashed lines.

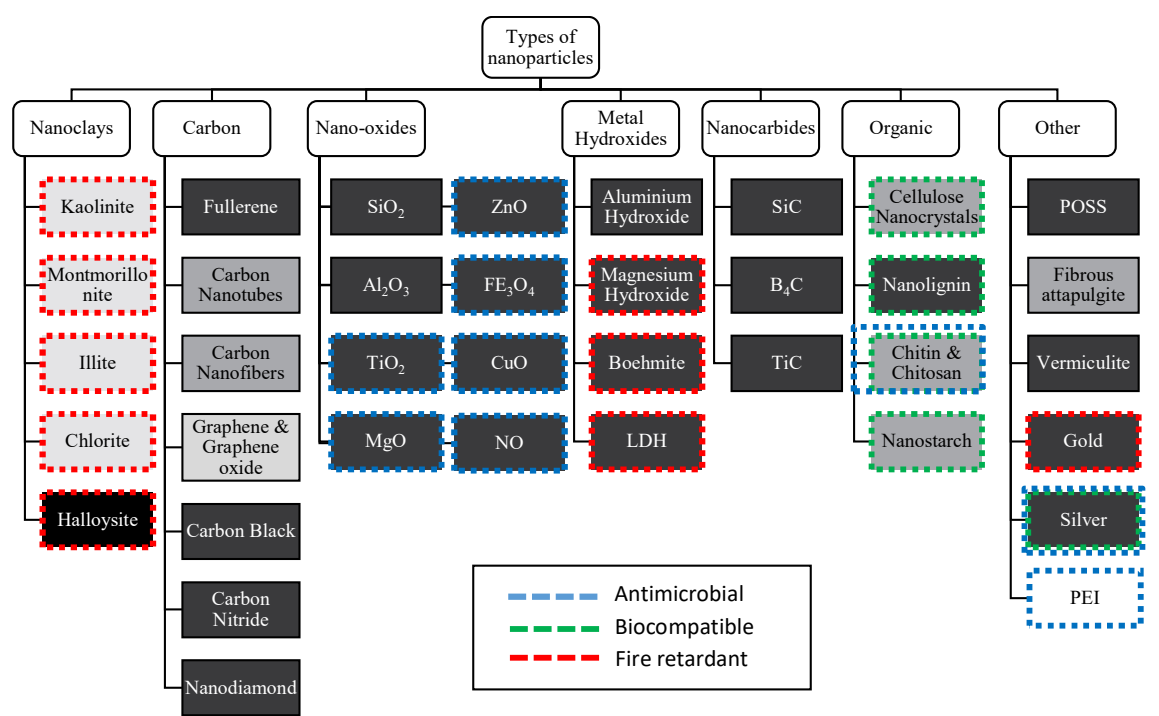

Shape and dimensional specifications of different types of nanofillers:
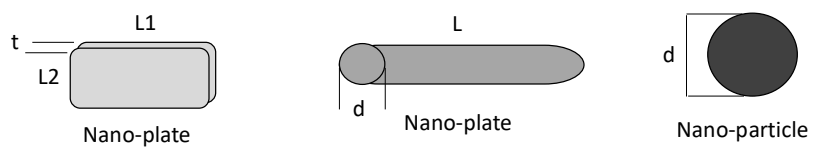

Fig. 1 - Types of nanofillers and the subcategories of each type. Dimensional and shape characteristics highlighted in different shades of grey; main application and properties highlighted in colored dashed lines.

\section{Nanofillers}

Nanofiller is the common term used for the additives having special structures and compositions, used in a small proportion together with the polymer matrix to generate a large impact on the final properties of the composite materials. New combinations of nanocomposites and hybrids have been developed in the recent past to achieve desired properties for applications such as humidity sensors [10], thermo responsive shape memory polymers [11], piezoresistive materials [12], etc. Besides the different combinations of properties based on the filler type and matrix used, the synthesis and preparation of these materials plays an important role in achieving 
desired properties of the materials [13]. In this section, the focus is placed on the combination of different nanofillers and matrixes for some advanced applications; the synthesis and preparation methods will also be briefly mentioned. Nanoparticles or nanofillers have been categorized in six different groups based on their origins: nanoclays, carbon, nano-oxides, metal hydroxides, nanocarbides, organic and other: including metal particles, silica oxides etc. (as shown in Figure 1). The incorporation of these nanofillers in different polymer matrixes can have a great impact on the mechanical, electrical or thermal properties but at the same time that can also have a negative impact on the environment. With the likelihood of these materials to end up in landfills, surface water and wastewater treatment, it is extremely important to study the biodegradability of the composites and to find green alternatives that enhanced the biodegradation of the materials. With the global concern about the waste problems caused by non-degradable plastics and composites, this paper will also present a list of novel alternatives at the end of each nanofiller section which can be greener options to the commonly used nanocomposites. The potential biodegradable polymer matrixes suitable for the green nanofillers such as the aliphatic polyesters: poly (lactic acid) (PLA), Poly(caprolactone) (PCL), poly (pdioxanone) (PPDO), poly(butyl succinate) (PBS), Poly (hydroxyalkanoates) (PHAs) etc. are presented and discussed in reference :[14].

\subsection{Nanoclays}

The most widely studied and commercially used nanofillers are nanoclays produced from natural clay minerals. Among different nanoclay types, the most common nanoclay is montmorillonites (MMTs), often called smectite or bentonite. The other nanoclay groups are kaolinite, illite, chlorite and halloysite [1]. Nanoclays are formed by stacked metal silicate layers which can be penetrated by low molecular weight substances, e.g. water, leading to swelling [8]. Depending on the degree of penetration into the interlayer,

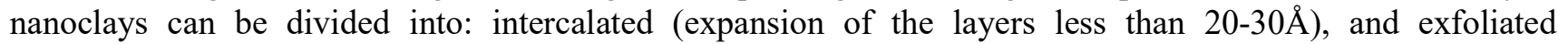
(expansion of the layers between $80-100 \AA$ or more) [1]. The best properties are given by the exfoliated nanoclays.

Kaolinite is a member of the nanoclay family which is the most abundant mineral on the earth. Kaolinite is a 1:1 layered dioctahedral aluminosilicate composed of alternating sheets of " $\mathrm{SiO}_{2}$ " and " $\mathrm{AlO}_{6}$ "[15]. MMT/ smectite / bentonite, characterized by a 2:1 sheet-structure, is the most widely used in the preparation of nanocomposites, since even in small quantities inside the polymer matrix, it has a big impact on the mechanical and thermal properties [16]. Illite and especially halloysite have received special attention in the recent years. Halloysite nanotubes (HNTs) are composed of silica and alumina with a structure similar to carbon nanotubes. However their biocompatibility and low price make them attractive replacements to CNT with promising applications in the medical industry e.g. drug delivery, implants, prostheses applications, etc.

Tables 1-4 represent the research studies made by the authors on the state-of-the-art literatures (from 2010 to 2017) on the nanoclay fillers. The polymeric matrixes include various types of thermoplastics, thermosets and elastomers. In order to facilitate the incorporation of these nanofillers into a polymer matrix, most of these clays are chemically modified. More variations of modified clays can be found in the review study done in 2015: [17]. In addition to their constituents, the tables also summarize the properties and applications, and the corresponding preparation method used for synthesis of the nanofillers. Figure 2 summarizes the symbols used the in tables by the authors to refer to the applications and application related properties of the nanofillers. These symbols are used throughout the paper to facilitate the selection of a nanofiller for a specific application or to impart a specific characteristic in the composite materials. This approach will make it easy to select nanofillers and nanocomposites for advanced application from huge number possibilities. 


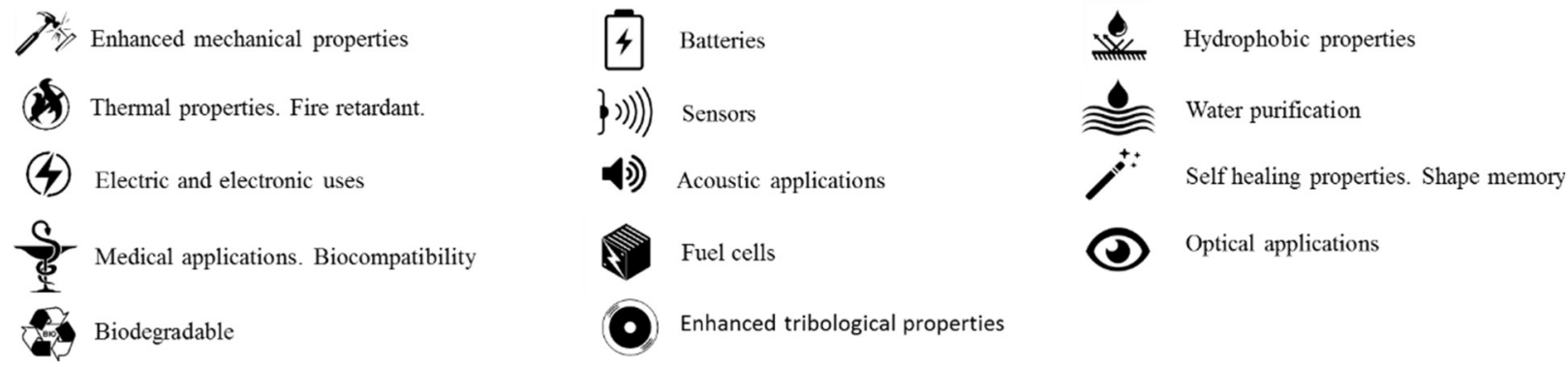

Fig. 2 - Categories for applications and properties of the studied nanofillers and the nanocomposites: the symbols are used by the authors to refer to the applications and application related properties of the nanofillers and the corresponding nanocomposites.

\subsubsection{Kaolinite}

Same as MMT, kaolinite can significantly enhance the polymer properties even in very small contents. The most common preparation methods for the synthesis of this filler are divided into three main groups. First, insitu intercalative polymerization (kaolinite is swollen by a liquid monomer solution; the reaction occurs in between the intercalated sheets). Moreover, solution intercalation (a solvent is used to exfoliate the single layers) and, melt intercalation (forces are applied to disperse the sheets in the polymer melt) are also used [18]. Novel approaches for other preparation methods are found in the following tables for various nanofillers. Major applications of kaolinite are focused on thermal properties, specifically to achieve fire retardant polymers while improving the mechanical properties of the nanocomposite. Table 1 summarizes the possible combinations of Kaolinite nanoclay with various polymer matrixes and lists their processing methods, modification agents (to enhance the interaction with polymer matrixes), properties and applications.

Table 1 - Kaolinite nanoclay combinations with polymer matrixes: processing methods, modification agents, properties and applications.

\begin{tabular}{|c|c|c|c|c|c|c|}
\hline & Plastic name & Preparation method & Modified/mixed with & Properties-applications & Field & Ref. \\
\hline \multirow{7}{*}{ 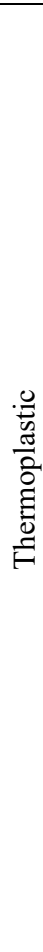 } & $\begin{array}{l}\text { Vinyl } \\
\text { alcohol } \\
\text { copolymer } \\
\text { (EVOH) }\end{array}$ & Melt intercalation & $\begin{array}{l}\text { Dimethyl-sulfoxide, } \\
\text { methanol and } \\
\text { octadecylamine }\end{array}$ & $\begin{array}{c}\text { Better thermal resistance, glass } \\
\text { transition temperature, crystallinity and } \\
\text { barrier properties to oxygen. }\end{array}$ & & {$[19,20]$} \\
\hline & \multirow{2}{*}{$\begin{array}{l}\text { Polyvinyl } \\
\text { alcohol } \\
\text { (PVA) }\end{array}$} & Melt intercalation & - & $\begin{array}{l}\text { Biomedical application: tissue } \\
\text { engineering and drug delivery. }\end{array}$ & & {$[21]$} \\
\hline & & $\begin{array}{l}\text { Preparation via } \\
\text { freezing-thawing } \\
\text { method }\end{array}$ & $\begin{array}{c}\text { Dimethyl sulfoxide } \\
\text { (DMSO) and potassium } \\
\text { acetate }\end{array}$ & $\begin{array}{l}\text { Decrease in the swelling ratio as well } \\
\text { as in the dehydration rate of } \\
\text { nanocomposite hydrogels. }\end{array}$ & & {$[22,23]$} \\
\hline & PA & $\begin{array}{l}\text { Melt compounding } \\
\text { dried ball- milling } \\
\text { mixture }\end{array}$ & $\mathrm{TiO}_{2}$-coated kaolinite & $\begin{array}{l}\text { Enhanced UV anti-aging and } \\
\text { mechanical properties. }\end{array}$ & & {$[24]$} \\
\hline & $\begin{array}{l}\text { Polystyrene } \\
\text { (PS) }\end{array}$ & $\begin{array}{l}\text { In situ emulsion } \\
\text { polymerization }\end{array}$ & $\begin{array}{l}\text { Intercalated with } \\
\text { dimethylsulfoxide } \\
\text { (DMSO) }\end{array}$ & $\begin{array}{l}\text { Slower thermal decomposition. Fire } \\
\text { retardant applications. }\end{array}$ & & {$[25,26]$} \\
\hline & $\begin{array}{l}\text { Polyarylami } \\
\text { de (PAA) }\end{array}$ & $\begin{array}{c}\text { In situ } \\
\text { polymerization }\end{array}$ & $\begin{array}{c}\text { Intercalated with } \\
\text { dimethyl-sulfoxide } \\
\text { (DMSO)/methanol and } \\
\text { potassium acetate } \\
\text { (KAc) }\end{array}$ & Salt-resistant super- absorbent. & & [27] \\
\hline & $\begin{array}{l}\text { Polyethylene } \\
\text { oxide (PEO) }\end{array}$ & $\begin{array}{c}\text { In situ } \\
\text { polymerization }\end{array}$ & $\begin{array}{l}\text { Urea as intercalating } \\
\text { agent }\end{array}$ & $\begin{array}{l}\text { Improved mechanical properties. } \\
\text { Suitable for lithium battery and } \\
\text { polymer electrolytes. }\end{array}$ & & [28] \\
\hline
\end{tabular}




\begin{tabular}{|c|c|c|c|c|c|c|}
\hline \multirow{2}{*}{ 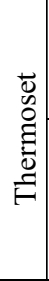 } & $\begin{array}{l}\text { Polyaniline } \\
\text { (PANI) }\end{array}$ & $\begin{array}{l}\text { In situ mechano- } \\
\text { chemical synthesis }\end{array}$ & - & $\begin{array}{l}\text { Improved thermal stability. } \\
\text { Corrosion resistance. } \\
\text { Marine applications. }\end{array}$ & (s) & [29] \\
\hline & Epoxy & Solvent-free method & $\begin{array}{l}\text { Modified with silylation } \\
\text { of } 3 \text { - } \\
\text { aminopropyltriethoxysil } \\
\text { ane }\end{array}$ & Improvement in the water resistance. & & [34] \\
\hline \multirow{2}{*}{ 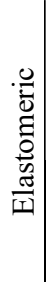 } & $\begin{array}{l}\text { Natural } \\
\text { rubber }\end{array}$ & $\begin{array}{l}\text { Vulcanization in a } \\
\text { sulfur curing system. }\end{array}$ & $\begin{array}{l}\text { Chlorinated } \\
\text { polyethylene and } \\
\text { alumina. }\end{array}$ & $\begin{array}{l}\text { Uses for insulation materials: noise and } \\
\text { vibration control of acoustic. } \\
\text { Absorbing material, thermal insulation } \\
\text { for building construction. }\end{array}$ & (1)) ( & {$[34]$} \\
\hline & $\begin{array}{l}\text { Styrene- } \\
\text { butadiene } \\
\text { rubber }\end{array}$ & Via melt blending & - & $\begin{array}{l}\text { Improvement of mechanical properties } \\
\text { and thermal stability. }\end{array}$ & & {$[32]$} \\
\hline
\end{tabular}

\subsubsection{Montmorillonite/ smectite / bentonite}

MMT is commonly used for fire retardancy purposes. Its combination with rubber matrix has shown a decrease in hydrogen and water permeability [33]. Due to its hydrophilic nature, the dispersion in a polymer matrix can be challenging. Therefore, it is common to find montmorillonite organically modified, with the purpose of improving dispersing capabilities and gelling absorption [34, 35]. Several recent studies include the application of these fillers for other purposes such as self-healing hydrogels with biocompatible properties [17, 36] with significantly improved mechanical properties. Table 2 collects several examples of research studies of different matrixes and MMT/ smectite / bentonite nanoclays published mostly between 2015 and 2018 .

Table 2 - Montmorillonite/ smectite / bentonite nanoclay combinations with polymer matrixes: processing methods, modification agents, properties and applications.

\begin{tabular}{|c|c|c|c|c|c|c|}
\hline & $\begin{array}{c}\text { Plastic } \\
\text { name }\end{array}$ & Preparation method & Modified/mixed with & Properties-applications & Field & Ref. \\
\hline \multirow{9}{*}{ 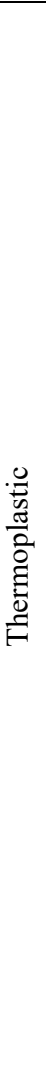 } & PUI & $\begin{array}{c}\text { Via in situ } \\
\text { polymerization }\end{array}$ & Hydroxyl-modified & $\begin{array}{l}\text { Heat and flame-resistant. Increment of } \\
\text { compression strength and modulus. }\end{array}$ & & [37] \\
\hline & PVA & $\begin{array}{l}\text { Solution-Intercalation } \\
\text { Method }\end{array}$ & - & $\begin{array}{l}\text { High strength, high stiffness, and } \\
\text { corrosion-resistant. Biocompatible. }\end{array}$ & & {$[38]$} \\
\hline & $\mathrm{PA}$ & $\begin{array}{l}\text { Intercalation through } \\
\text { ion exchange process }\end{array}$ & Amine hydro- chloride & $\begin{array}{c}\text { Drug Delivery System. Antimicrobial } \\
\text { activity }\end{array}$ & & [41] \\
\hline & PS & In-situ Polymerization & - & Higher resistance to gas permeability & & [44] \\
\hline & PAA & $\begin{array}{l}\text { Via simple UV } \\
\text { irradiation } \\
\text { polymerization }\end{array}$ & - & $\begin{array}{l}\text { Increase water absorbency of } \\
\text { hydrogels. Improved mechanical } \\
\text { properties and recoverability. }\end{array}$ & & [36] \\
\hline & $\begin{array}{l}\text { Polymethyl } \\
\text { methacrylat } \\
\text { e (PMMA) }\end{array}$ & Melt blending & $\begin{array}{l}\text { Cation-exchange } \\
\text { reaction of Na-MMT } \\
\text { with hexadecyl } \\
\text { trimethyl ammonium } \\
\text { bromide } \\
\end{array}$ & $\begin{array}{c}\text { Better surface roughness for better } \\
\text { adhesion, wettability, and printability } \\
\text { properties. }\end{array}$ & & [43] \\
\hline & PEO & Melt intercalation & $\begin{array}{l}\text { Intercalated with } \\
\text { lithium }\end{array}$ & $\begin{array}{l}\text { Better thermal stability, higher ionic } \\
\text { conductivity. Used for ion secondary } \\
\text { batteries. }\end{array}$ & & [44] \\
\hline & $\mathrm{PP}$ & Mechanical mixing & - & $\begin{array}{l}\text { Waste containment barriers } \\
\text { applications. Improved mechanical } \\
\text { properties. }\end{array}$ & & $\begin{array}{c}51] \\
52]\end{array}$ \\
\hline & $\begin{array}{l}\text { Polyvinylpy } \\
\text { rrolidone } \\
\text { (PVP) }\end{array}$ & Solution mixing & - & $\begin{array}{l}\text { Enhanced modulus, higher thermal } \\
\text { stability and improved moisture } \\
\text { resistance properties. Biodegradability. }\end{array}$ & & [47] \\
\hline
\end{tabular}




\begin{tabular}{|c|c|c|c|c|c|c|}
\hline & PTFE & Ultrasonic mixing & Organically modified & $\begin{array}{l}\text { Improved permeability, water } \\
\text { retention, and proton conductivity of } \\
\text { proton exchange membrane for fuel } \\
\text { cells. }\end{array}$ & & [34] \\
\hline & $\begin{array}{l}\text { Polyethersu } \\
\text { lfone (PES) }\end{array}$ & $\begin{array}{l}\text { Solution dispersion } \\
\text { and wet-phase } \\
\text { inversion methods }\end{array}$ & Organically modified & $\begin{array}{l}\text { Improved the mechanical properties } \\
\text { and thermal stability. Removal of } \\
\text { pesticides. }\end{array}$ & & $\begin{array}{r}{[48,} \\
49]\end{array}$ \\
\hline \multirow{4}{*}{ 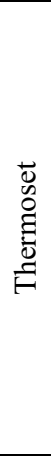 } & PANI & In situ polymerization & $\begin{array}{l}\text { Sodium dodecyl } \\
\text { benzene sulphonate } \\
\text { (DPM) }\end{array}$ & $\begin{array}{l}\text { Reduce flammability and toxicity. } \\
\text { Electrical conductivity. }\end{array}$ & & {$[4]$} \\
\hline & \multirow[t]{2}{*}{ Epoxy } & In situ polymerization & - & $\begin{array}{l}\text { Moisture absorption minimization: } \\
\text { improve aircraft radome longevity. }\end{array}$ & & {$[50]$} \\
\hline & & Intercalation & $\begin{array}{l}\text { Silicone-intercalated } \\
\text { organic MMT }\end{array}$ & Enhanced damping properties. & & {$[51]$} \\
\hline & $\begin{array}{c}\text { Liquid } \\
\text { crystalline } \\
\text { polymer } \\
(\mathrm{LCP})\end{array}$ & Solvent casting & Organically modified & $\begin{array}{c}\text { Enhancement in the degradation } \\
\text { temperature. High-frequency electronic } \\
\text { applications. }\end{array}$ & & {$[52]$} \\
\hline \multirow{3}{*}{ 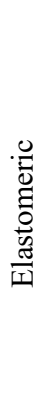 } & $\begin{array}{l}\text { Natural } \\
\text { rubber }\end{array}$ & Single-stage mixing & $\begin{array}{l}\text { Grafting Stearyl Amine } \\
\text { Ethoxylate }\end{array}$ & $\begin{array}{l}\text { Improvements in the mechanical } \\
\text { properties. }\end{array}$ & & $\begin{array}{l}{[33,} \\
35, \\
53- \\
56]\end{array}$ \\
\hline & $\begin{array}{l}\text { Styrene- } \\
\text { butadiene } \\
\text { rubber }\end{array}$ & Mixing and curing & $\begin{array}{l}\text { Modified with dimethyl, } \\
\text { benzyl, one alkyl tail } \\
\text { i.e. hydrogenated tallow } \\
\text { HT }\end{array}$ & Lower relaxation rate. & & {$[56]$} \\
\hline & Silicone & Solution mixing & - & $\begin{array}{l}\text { Improve heat ageing and thermal } \\
\text { properties. }\end{array}$ & & {$[57]$} \\
\hline
\end{tabular}

\subsubsection{Illite}

Compared to MMT which is a smectite clay with small nanolayers, illite has larger nanolayers. The higher aspect ratios enhance the mechanical properties and the thermal stability of the polymer matrixes. Nevertheless, illite has been far less explored as reinforcement agent in polymer nanocomposites, compared to the other nanoclays [58]. The interest in using the nanoclay alternatives has been due to the environmental impact of petroleum-based superabsorbent. From the illitization of smectite, a mixed layer clay: illite/smectite, has been developed for superabsorbent hydrogels which can be of great interest in agriculture, hygiene products, drug delivery, wastewater treatment, etc. [59]. Their Polyethylene Oxide (PEO) based composites, can be used to construct solid polymer electrolytes for rechargeable polymer lithium batteries [58]. More examples of applications and properties are listed in the Table 3.

Table 3 - Illite combinations with polymer matrixes: processing methods, modification, properties and applications.

\begin{tabular}{|c|c|c|c|c|c|c|c|}
\hline & Plastic name & $\begin{array}{c}\text { Preparation } \\
\text { method }\end{array}$ & Modified/mixed with & Properties-applications & Field & Ref. & Year \\
\hline \multirow{2}{*}{ 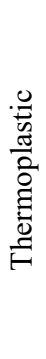 } & $\begin{array}{l}\text { Polyethylene } \\
\text { Oxide (PEO) }\end{array}$ & Exfoliation & $\begin{array}{l}\text { Deintercalation of } \\
\text { dimethyl sulfoxide } \\
\text { (DMSO) }\end{array}$ & $\begin{array}{l}\text { Ability to dissolve salts } \\
\text { ensuring a high ionic } \\
\text { mobility. Lithium battery } \\
\text { applications. }\end{array}$ & 4 & {$[60]$} & 2016 \\
\hline & $\begin{array}{l}\text { Polypropelene } \\
\text { (PP) }\end{array}$ & - & $\begin{array}{l}\text { Fluorination of illite and } \\
\text { modified with 3- } \\
\text { aminopropyltrimethox- } \\
\text { ysilane and hexadecyl- } \\
\text { trimethoxysilane }\end{array}$ & $\begin{array}{l}\text { Better thermal stability and } \\
\text { flame retardancy, and } \\
\text { mechanical properties. }\end{array}$ & & {$[61]$} & 2012 \\
\hline
\end{tabular}




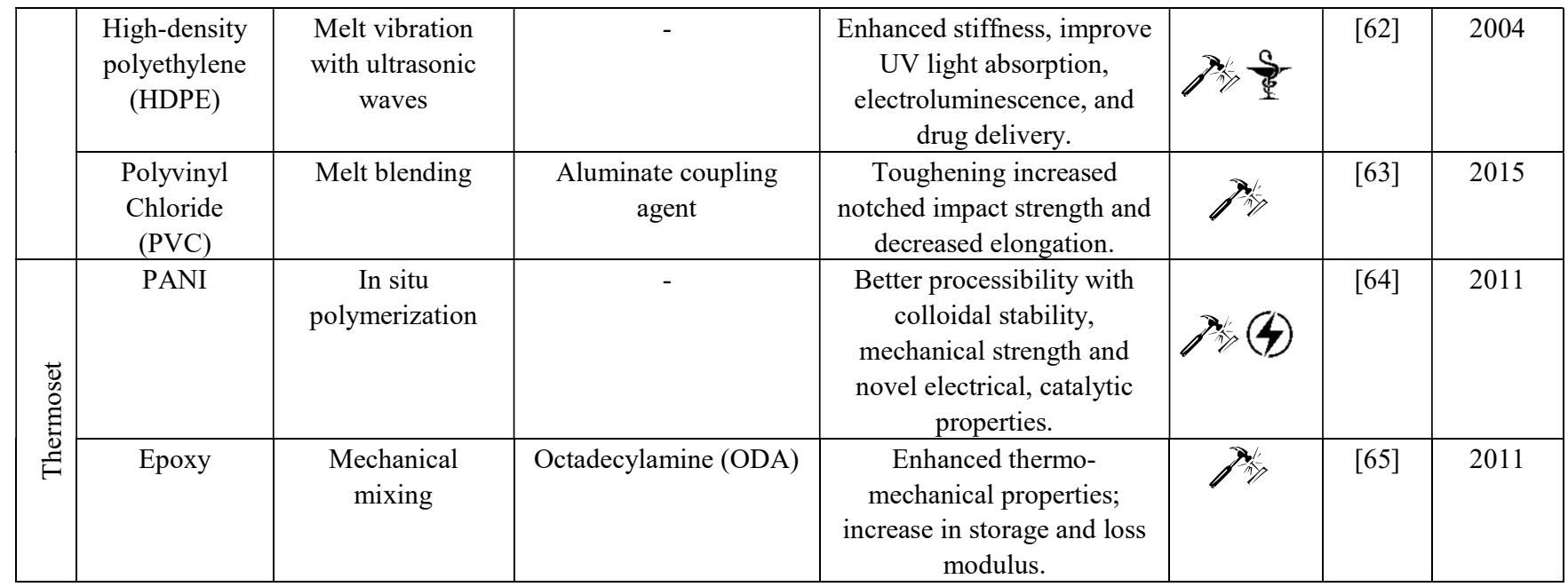

\subsubsection{Halloysite}

Halloysite is a member of kaolin group, which has attracted interest in many recent studies. Although they are similar to the rest of nanoclays, their structure is much similar to nanotubes. However their production costs are much lower [66]. The main application fields of these nanofillers are: flame retardancy, anticorrosion, dye removal, and drug delivery and recently, stimuli-response. A detailed review dating from 2017 presents more information about this nanofillers (origins, applications and matrix combinations): [67]. The main characteristics of these nanofillers including their combinations with different polymer matrixes, preparation methods, modification agents, properties and possible application areas are presented in the table below.

Table 4 - Halloysite combinations with polymer matrixes: processing methods, modification as well as properties and applications.

\begin{tabular}{|c|c|c|c|c|c|c|}
\hline & Plastic name & Preparation method & Modified/mixed with & Properties-applications & Field & Ref. \\
\hline \multirow{5}{*}{ 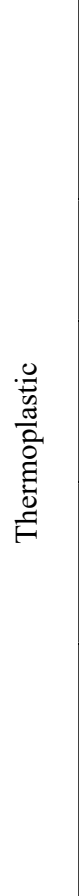 } & $\begin{array}{c}\text { PVA } \\
\text { hydrogel }\end{array}$ & Freeze-thawing & - & $\begin{array}{c}\text { Substitute for articular cartilage, } \\
\text { drug delivery, contact lenses, } \\
\text { wound dressing, and artificial } \\
\text { organs. Better mechanical } \\
\text { properties. }\end{array}$ & & {$[68]$} \\
\hline & $\mathrm{PA}$ & $\begin{array}{l}\text { Via in situ interfacial } \\
\text { polymerization. }\end{array}$ & - & $\begin{array}{l}\text { Higher hydrophilicity: potential use } \\
\text { for reverse osmosis (RO) } \\
\text { (wastewater treatment). }\end{array}$ & & [69] \\
\hline & PMMA & Mechanical mixing & Barium-coated & $\begin{array}{l}\text { Cytocompatible. Implantation and } \\
\text { fixation of prostheses to the bone. } \\
\text { Enhancement of mechanical } \\
\text { properties. }\end{array}$ & & $\begin{array}{r}{[70-} \\
72]\end{array}$ \\
\hline & $\begin{array}{l}\text { Poly(butylen } \\
\text { e succinate) } \\
\text { (PBS) }\end{array}$ & Solvent casting & $\begin{array}{l}\text { Sodium dodecanoate } \\
\text { (NaL) } \\
\text { Loaded with } \\
\text { poly(ethylene glycol) }\end{array}$ & Increased hydrophilicity. & & [73] \\
\hline & PES & Phase inversion & $\begin{array}{l}\text { Immobilized } \\
\text { lysozyme }\end{array}$ & $\begin{array}{l}\text { Improved surface hydrophilicity } \\
\text { and water flux. Enhanced } \\
\text { mechanical strength and good } \\
\text { antibacterial activity. } \\
\text { Application: reduce fouling in } \\
\text { water treatment. }\end{array}$ & & {$[74]$} \\
\hline 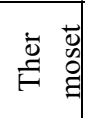 & $\begin{array}{l}\text { Polyaniline } \\
\text { (PANI) }\end{array}$ & $\begin{array}{l}\text { In situ chemical } \\
\text { polymerization }\end{array}$ & Cyclohexene & $\begin{array}{l}\text { Fabrication of a polymer-based } \\
\text { green catalyst system. }\end{array}$ & & {$[75]$} \\
\hline
\end{tabular}




\begin{tabular}{|c|c|c|c|c|c|}
\hline & Epoxy & Mechanical mixing & $\begin{array}{l}\text { Amine hardener } \\
\text { immobilized } \\
\text { mesoporous silica }\end{array}$ & $\begin{array}{l}\text { Better waterproofing property. Self- } \\
\text { healing. Epoxy coating for carbon } \\
\text { steel. Outdoor applications. }\end{array}$ & $\begin{array}{c}{[76-} \\
78]\end{array}$ \\
\hline & $\begin{array}{l}\text { Polyester } \\
\text { Resin }\end{array}$ & Mechanical mixing & Silica nanoparticles & $\begin{array}{l}\text { Application: aerospace, } \\
\text { automobiles and building materials. }\end{array}$ & [79] \\
\hline 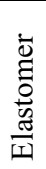 & $\begin{array}{l}\text { Natural } \\
\text { rubber }\end{array}$ & - & $\begin{array}{c}2- \\
\text { mercaptobenzimidazo } \\
\text { le }(\mathrm{MB})\end{array}$ & $\begin{array}{l}\text { Antioxidative efficiency. Better } \\
\text { mechanical performances (tensile } \\
\text { strength, tear strength and heat } \\
\text { buildup). }\end{array}$ & $\begin{array}{l}{[80,} \\
81]\end{array}$ \\
\hline
\end{tabular}

\subsubsection{A green approach to nanoclay filled composites}

MMT and halloysite nanoclays have been the most extensively studied nanoclays with biodegradable properties. Polylactic acid (PLA) has received most of the attention as biodegradable polymer matrix, not only for nanoclays but for also for other nanofillers. Although, PLA presents good mechanical properties, its applications are limited in critical areas such as electronics and the automotive industry due to its flammability. As seen in the previous sections, nanoclays have been used as fire retardants for other polymer matrixes, making them potential candidates to transform PLA into a green and improved nanocomposite where flame retardancy is critical. The table below summarizes a series of studies that provide biodegradable nanocomposites using nanoclay fillers that include PLA as well as other polymeric matrixes.

Table 5 - Novel research studies of biodegradable nanocomposites using nanoclay nanofillers.

\begin{tabular}{|c|c|c|c|c|c|c|}
\hline $\begin{array}{l}\text { Matrix polymer } \\
\text { name }\end{array}$ & Nanoclay type & $\begin{array}{l}\text { Preparatio } \\
\mathrm{n} \text { method }\end{array}$ & $\begin{array}{l}\text { Modified/mix } \\
\text { ed with }\end{array}$ & Properties-applications & Field & Ref. \\
\hline PLA & $\begin{array}{l}\text { Cloisite 30B } \\
\text { (MMT) }\end{array}$ & & $\begin{array}{l}\text { Melamine } \\
\text { polyphosphate } \\
\text { (MPP) }\end{array}$ & Flame retardant. 3D printing & & {$[82]$} \\
\hline $\begin{array}{c}\text { Poly (butylene } \\
\text { adipate-co- } \\
\text { terephthalate) } \\
\text { (PBAT) and } \\
\text { thermoplastic starch } \\
\text { (TPS) }\end{array}$ & Sepiolite & & - & $\begin{array}{l}\text { Enhanced thermal and mechanical } \\
\text { properties. Lower water absorption } \\
\text { rate. } \\
\text { Short term applications; packaging, } \\
\text { agriculture and hygiene. }\end{array}$ & & [83] \\
\hline $\begin{array}{l}\text { Acrylic acid (AA) } \\
\text { monomer }\end{array}$ & MMT & $\begin{array}{l}\text { In situ } \\
\text { polymeriz } \\
\text { ation }\end{array}$ & $\begin{array}{l}\text { Salep (multi- } \\
\text { component } \\
\text { polysaccharid } \\
\text { e) }\end{array}$ & $\begin{array}{l}\text { Porous hydrogel with high swelling } \\
\text { capacity. Candidate for agricultural } \\
\text { and horticultural applications } \\
\text { (reservoir systems) }\end{array}$ & & {$[84]$} \\
\hline $\begin{array}{l}\text { Cellulose acetate } \\
\text { (CA)/poly-L-lactic } \\
\text { acid (PLLA)/ }\end{array}$ & $\begin{array}{l}\text { Halloysite } \\
\text { nanotube }\end{array}$ & $\begin{array}{l}\text { Electrospi } \\
\text { nning }\end{array}$ & - & $\begin{array}{l}\text { Used for gel polymer electrolytes } \\
\text { (GPEs) for lithium-ion } \\
\text { batteries. }\end{array}$ & 4 & {$[85]$} \\
\hline PLA & $\begin{array}{l}\text { Halloysite } \\
\text { nanotube }\end{array}$ & $\begin{array}{c}\text { Melt } \\
\text { blending }\end{array}$ & - & $\begin{array}{l}\text { Increased tensile strength and } \\
\text { Young's modulus and storage } \\
\text { modulus. }\end{array}$ & & {$[86]$} \\
\hline $\begin{array}{c}\text { Poly (butylene } \\
\text { succinate-co- } \\
\text { adipate) (PBSA) and } \\
\text { maleated } \\
\text { polyethylene } \\
\text { (PEgMA) } \\
\end{array}$ & $\begin{array}{c}\text { Halloysite } \\
\text { nanotube and } \\
\text { MMT }\end{array}$ & $\begin{array}{c}\text { Melt } \\
\text { blending }\end{array}$ & - & $\begin{array}{l}\text { Increased thermal stability with } \\
\text { MMT, but not with halloysite } \\
\text { nanotubes. Superior rigidity and } \\
\text { water uptake rate. }\end{array}$ & & [87] \\
\hline
\end{tabular}




\begin{tabular}{|c|c|c|c|c|c|}
\hline PVA-PVP & $\begin{array}{c}\text { Halloysite } \\
\text { nanotube }\end{array}$ & $\begin{array}{c}\text { Crosslinki } \\
\text { ng }\end{array}$ & - & Application in the dentistry field \\
\hline Polyester (PEST) & $\begin{array}{c}\text { Halloysite } \\
\text { nanotube }\end{array}$ & $\begin{array}{c}\text { Solution } \\
\text { casting }\end{array}$ & & $\begin{array}{c}\text { Increased storage modulus, tensile } \\
\text { and flexural properties as well as } \\
\text { fracture toughness, surface } \\
\text { roughness and glass transition } \\
\text { temperature. }\end{array}$ & \begin{tabular}{c} 
[89] \\
\hline
\end{tabular} \\
\hline
\end{tabular}

\subsection{Carbon Nanoparticles}

The two first known forms of Carbon Nanoparticles were diamond and graphite. However, the seminal researches in 1980s and 1990s lead to the discovery of other allotropes of carbon including fullerene and carbon nanotubes (single and multi-walled: SWCNT and MWCNT). The more recent form is graphene which was recognized around 2007 as a nanofiller for plastic composites. Carbon black has been the most studied so far for the creation of nanocomposites for mechanical and thermal enhancement. However the new forms of carbon nanoparticles are raising unprecedented interest in many areas such as electronics devices, smart materials, electromagnetic shielding, etc. [1]. Similar to the previous section for nanoclays, different studies from the combination of matrixes and carbon particles are presented along with their important modification methods, properties and application areas are extracted from the sate-of-the-art literatures and presented in the sub-sections below.

\subsubsection{Fullerene}

Fullerene presents remarkable properties when synthesized with polymers, providing enhanced mechanical, thermal, electrical, optical, and photovoltaic properties. Nevertheless, the synthesis processes, unlike nanoclays, are still in early stage of development. They are generally used for photovoltaic applications, temperature sensors, and antimicrobial applications among other [90]. Table 6 summarizes the information for Fullerene about the potential polymer matrixes, processing methods, modification as well as properties and applications.

Table 6 -Fullerene combinations with polymer matrixes: processing methods, modification as well as properties and applications.

\begin{tabular}{|c|c|c|c|c|c|c|}
\hline & Plastic name & Preparation method & $\begin{array}{l}\text { Modified/mixed } \\
\text { with }\end{array}$ & Properties-applications & Field & Ref. \\
\hline \multirow{3}{*}{ 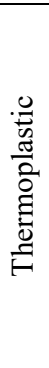 } & $\begin{array}{c}\text { Thermoplastic } \\
\text { polyurethane (TPU) }\end{array}$ & Prepolymer method & $\begin{array}{l}\text { Urethanized } \\
\text { fullerene }\end{array}$ & $\begin{array}{l}\text { Improve TPU durability by reducing } \\
\text { oxidation. Reduced gas permeability. }\end{array}$ & & [91] \\
\hline & $\begin{array}{l}\text { Poly-ether-ether- } \\
\text { ketone (PEEK) } \\
\text { composites. }\end{array}$ & $\begin{array}{l}\text { Low-temperature } \\
\text { sintering }\end{array}$ & - & Lower wear rate. & & [92] \\
\hline & $\begin{array}{l}\text { Poly (phenylene } \\
\text { sulfide) (PPS) }\end{array}$ & $\begin{array}{l}\text { Solution co-blending } \\
\text { method }\end{array}$ & - & $\begin{array}{l}\text { Excellent electrical conductivity, } \\
\text { increased crystallization temperature, } \\
\text { thermal stability and mechanical } \\
\text { performance. }\end{array}$ & & [93] \\
\hline \multirow{2}{*}{ 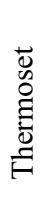 } & $\begin{array}{l}\text { Liquid crystalline } \\
\text { polyester (LCP) }\end{array}$ & - & - & Shape memory behavior. & & [94] \\
\hline & Epoxy & - & - & Electrical insulation. & & [95] \\
\hline 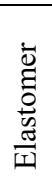 & Natural Rubber & - & - & $\begin{array}{l}\text { Influence on the dielectric properties } \\
\text { and increase of coefficient of } \\
\text { reflection of microwaves in the 6-12 } \\
\text { GHz range. }\end{array}$ & & [96] \\
\hline
\end{tabular}




\subsubsection{CNTS}

CNTs are graphene sheets that are rolled to form tubes. At certain loading fraction, so called "percolation threshold", these fillers provide the matrix electrical conductivity due to the network created. Based on their layer configurations, these nanotubes can be divided in single-walled nanotubes (SWCNTs) and multi-walled nanotubes (MWCNTs) (Fig. 1). Carbon nanotubes due to their special atomic configuration exhibit extraordinary properties such very high stiffness, superior thermal and electrical conductivity, etc. Therefore, they have been interesting for many multifunctional applications especially in lightweight structures. In the recent years, CNTs have been used extensively in nanocomposites hydrogels which have numerous applications for tissue engineering, sensors, solar cells, biomedicine, actuators, biofuels, antennas, solar energy conversion, etc. $[97,98]$. Summary of the recent research studies on CNTs for different application areas are presented in Table 7.

Table 7 -CNTs combinations with polymer matrixes: processing methods, modification as well as properties and applications.

\begin{tabular}{|c|c|c|c|c|c|c|c|}
\hline & Plastic name & Preparation method & $\begin{array}{l}\text { Modified/mixed } \\
\text { with }\end{array}$ & $\begin{array}{l}\text { Type of } \\
\text { CNT }\end{array}$ & Properties-applications & & Ref. \\
\hline \multirow{6}{*}{ 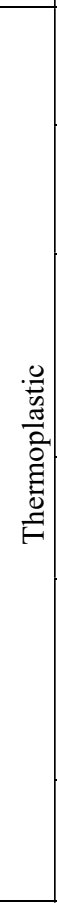 } & ABS & Melt mixing & TPU & MWCNTs & $\begin{array}{c}\text { Increased shape recovery } \\
\text { ratio. }\end{array}$ & & [99] \\
\hline & Aromatic PA & $\begin{array}{c}\text { Interfacial } \\
\text { polymerization }\end{array}$ & & MWCNTs & $\begin{array}{l}\text { Reverse osmosis } \\
\text { membrane (water } \\
\text { purification). }\end{array}$ & & {$[100]$} \\
\hline & PA 66 & Melt compounding & & MWCNTs & $\begin{array}{l}\text { Multifunctional electrical- } \\
\text { mechanical composites. } \\
\text { Structural and EMI } \\
\text { shielding applications }\end{array}$ & $(4)$ & $\begin{array}{c}{[101,1} \\
02]\end{array}$ \\
\hline & PVA- & - & $\begin{array}{l}\text { Poly(ethylene } \\
\text { oxide) (PEO) and } \\
\text { chitosan }\end{array}$ & MWCNTs & Detection of polar vapors. & (3)))) (4) & [103] \\
\hline & $\begin{array}{c}\text { TPE } \\
\text { (styrene- } \\
\text { butadiene- } \\
\text { styrene } \\
\text { (SBS)) }\end{array}$ & Up-scalable extrusion & - & MWCNTs & $\begin{array}{l}\text { Increased mechanical } \\
\text { modulus, larger } \\
\text { deformations and electro } \\
\text { mechanical stability. Use } \\
\text { for strain sensors. }\end{array}$ & $\begin{array}{c}2(j)))) \\
(4)\end{array}$ & [104] \\
\hline & PP & $\begin{array}{c}\text { Solution processing and } \\
\text { melt blending }\end{array}$ & - & MWCNTs & $\begin{array}{l}\text { Enhancement of modulus, } \\
\text { tensile strength and } \\
\text { impact strength. }\end{array}$ & A & {$[105]$} \\
\hline \multirow{3}{*}{ 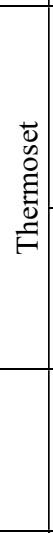 } & PANI & In situ polymerization & Graphene & MWCNTs & $\begin{array}{c}\text { Extraordinary } \\
\text { electrochemical } \\
\text { performance. Electrode } \\
\text { material for energy } \\
\text { storage: super capacitors. }\end{array}$ & & {$[106]$} \\
\hline & Epoxy & - & Graphene & MWCNTs & $\begin{array}{l}\text { Improved thermal and } \\
\text { optical properties } \\
\text { Absorber plates for fresh } \\
\text { water productivity. }\end{array}$ & 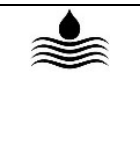 & {$[107]$} \\
\hline & Epoxy & $\begin{array}{l}\text { Solution mixing and } \\
\text { ultrasonication }\end{array}$ & - & MWCNTs & $\begin{array}{l}\text { Improved friction and } \\
\text { scratch resistance- } \\
\text { painting and } \\
\text { microelectronics }\end{array}$ & & [108] \\
\hline 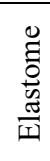 & $\begin{array}{l}\text { Natural } \\
\text { rubber }\end{array}$ & - & Carbon Black & MWCNTs & $\begin{array}{c}\text { Health monitoring, } \\
\text { sensors in different } \\
\text { dynamic elastomeric parts } \\
\text { like tires, valves, gaskets, }\end{array}$ & (১)))) & [109] \\
\hline
\end{tabular}




\begin{tabular}{|c|c|c|c|c|c|c|}
\hline & & & & $\begin{array}{c}\text { engine mounts or even } \\
\text { human finger motion } \\
\text { detections. }\end{array}$ & & \\
\hline $\begin{array}{l}\text { Styrene- } \\
\text { butadiene } \\
\text { Rubber } \\
\text { (SBR), }\end{array}$ & - & - & MWCNTs & $\begin{array}{l}\text { Force sensor for } \\
\text { monitoring automotive } \\
\text { tire deformation. }\end{array}$ & $(\rho))))(4)$ & {$[110]$} \\
\hline
\end{tabular}

\subsubsection{Graphene and Graphene Oxide}

Research studies on Graphene and Graphene oxide based nanocomposites have increased in the recent years. Graphene nanofillers such as carbon nanotubes exhibit exceptional properties. Therefore, they are studied for many novel advanced applications such as polysulfone membranes; thermally interface materials, microelectronics, etc. More and more research studies have been done for water purification purposes, antibacterial materials for medical applications as well as for different sensor applications. Graphene based nanocomposites membranes have received special attention, although most of the recent studies will require further investigations for an ideal functionality [111]. Table 8 presents the research studies on different forms of graphene in combinations with polymer matrixes, processing methods, modification, properties and applications.

Table 8 - Research studies of different forms of graphene in combinations with polymer matrixes: processing methods, modification, properties and applications.

\begin{tabular}{|c|c|c|c|c|c|c|c|}
\hline & Plastic name & $\begin{array}{c}\text { Preparatio } \\
\text { n method }\end{array}$ & $\begin{array}{l}\text { Modified/mix } \\
\text { ed with }\end{array}$ & Type & Properties-applications & & Ref. \\
\hline \multirow{6}{*}{ 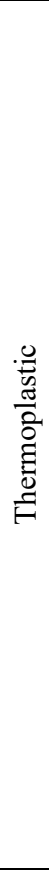 } & $\begin{array}{c}\text { Polyacrylic acid } \\
\text { functionalized (PAA) }\end{array}$ & $\begin{array}{l}\text { Facile } \\
\text { method }\end{array}$ & - & $\begin{array}{l}\text { Magnetic } \\
\text { graphene } \\
\text { oxide }\end{array}$ & $\begin{array}{c}\text { Removal of cationic organic } \\
\text { pollutants in wastewater } \\
\text { treatment. Recyclable and } \\
\text { reusable. }\end{array}$ & & {$[112]$} \\
\hline & Polycarbonate (PC) & $\begin{array}{l}\text { Solution } \\
\text { blending }\end{array}$ & - & & $\begin{array}{l}\text { Antibacterial activities against E. } \\
\text { coli and S. aureus. }\end{array}$ & 鍳 & {$[113]$} \\
\hline & PES & $\begin{array}{l}\text { Solution } \\
\text { blending }\end{array}$ & $\mathrm{TiO}_{2}$ & $\begin{array}{l}\text { Reduced } \\
\text { graphene } \\
\text { oxide }\end{array}$ & $\begin{array}{c}\text { Nanofiltration technology, water } \\
\text { softening and filtration, improve } \\
\text { the hydrophobicity, antibacterial } \\
\text { properties, and low toxicity. }\end{array}$ & & {$[114]$} \\
\hline & Polyurethane (PU) & $\begin{array}{c}\text { Melt } \\
\text { blending }\end{array}$ & (PEEAMA) & Graphene & $\begin{array}{c}\text { Thermo-responsive shape } \\
\text { memory properties. }\end{array}$ & & [11] \\
\hline & PVC & $\begin{array}{l}\text { Solution } \\
\text { blending }\end{array}$ & - & $\begin{array}{l}\text { Reduced } \\
\text { Graphene } \\
\text { Oxide } \\
\text { Thermally } \\
\end{array}$ & $\begin{array}{l}\text { Improvement of the tensile } \\
\text { strength and tensile modulus. }\end{array}$ & & {$[115]$} \\
\hline & Polysulfone (PSU) & $\begin{array}{l}\text { Solution } \\
\text { blending }\end{array}$ & - & $\begin{array}{l}\text { Reduced } \\
\text { graphene } \\
\text { oxide }\end{array}$ & $\begin{array}{l}\text { Antibacterial properties against } \\
\text { Bacilus subtilis and Escherichia } \\
\text { coli. Applications involving } \\
\text { human exposure. }\end{array}$ & & {$[116]$} \\
\hline \multirow{3}{*}{ 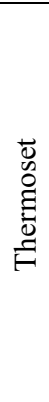 } & Epoxy & $\begin{array}{l}\text { In situ } \\
\text { prepolyme } \\
\text { rization } \\
\end{array}$ & - & Graphene & $\begin{array}{c}\text { Enhanced corrosion resistance, } \\
\text { UV stability, and impact } \\
\text { resistance. }\end{array}$ & & {$[117]$} \\
\hline & LCP & $\begin{array}{l}\text { In situ } \\
\text { prepolyme } \\
\text { rization }\end{array}$ & - & $\begin{array}{l}\text { Graphene } \\
\text { oxide }\end{array}$ & $\begin{array}{l}\text { Enhancement mechanical } \\
\text { properties and the thermal } \\
\text { stability. Better creep stability } \\
\text { thermo mechanical behavior. }\end{array}$ & & {$[118]$} \\
\hline & PANI & $\begin{array}{l}\text { Nanoemul } \\
\text { sion } \\
\text { method }\end{array}$ & $\mathrm{ZnO}$ & $\begin{array}{l}\text { Graphene } \\
\text { oxide }\end{array}$ & Gas sensing of ammonia. & (ر)))) & {$[119]$} \\
\hline
\end{tabular}




\begin{tabular}{|c|c|c|c|c|c|c|c|}
\hline$\overline{0}$ & Silicone Rubber & $\begin{array}{l}\text { Liquid } \\
\text { mixing } \\
\text { method }\end{array}$ & Carbon Black & Graphene & Flexible piezoresistive sensors. & $(\jmath))))$ & {$[12]$} \\
\hline 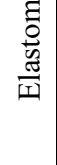 & SBR & $\begin{array}{l}\text { Modified } \\
\text { Hummer's } \\
\text { method }\end{array}$ & $\begin{array}{c}\text { Carboxylated } \\
\text { acrylonitrile } \\
\text { butadiene } \\
\text { rubber }\end{array}$ & $\begin{array}{c}\text { Graphene } \\
\text { oxide }\end{array}$ & $\begin{array}{c}\text { Better thermal stability and } \\
\text { solvent resistance. Tire } \\
\text { manufacture. }\end{array}$ & (4) & [120] \\
\hline
\end{tabular}

\subsubsection{Carbon Black}

Carbon black (CB) has been widely used due to its abundancy, low cost, and its self-networking capabilities (self-organizing into three-dimensional continuous networks). This carbonic filler has been used in polymer matrixes such as in tire and manufactured rubber applications, replacement of tire market being the larger sector in world for carbon black demand [121]. Other applications, due to their homogeneous dispersion in polymer matrixes are: super capacitors, batteries, sensors, fuelcells etc. [122]. Its black pigment has also been used for coloring pigments and paints. One of the most interesting application however, same as the other carbon nanofillers, is for electric and electronic application: electromagnetic shielding, thermoelectric energy conversion, electrical switching etc. Unlike CNTs \& CNFs however, this filler is not effective for shape memory polymers [123]. For the best electrical properties, CB particles must have small diameters and high surface area, which means that the dispersion in the polymer matrix is highly important. However, the modification of $\mathrm{CB}$ in order to simplify the dispersion in the polymer matrix reduces the electrical properties [1]. Table 9 summarizes possible polymer matrixes for $\mathrm{CB}$, thier processing methods, modification as well as properties and applications.

Table 9 -Carbon Black combinations with polymer matrixes: processing methods, modification as well as properties and applications.

\begin{tabular}{|c|c|c|c|c|c|c|}
\hline & Plastic name & Preparation method & $\begin{array}{c}\text { Modified/mixe } \\
\text { d with }\end{array}$ & Properties-applications & & Ref. \\
\hline \multirow{4}{*}{ 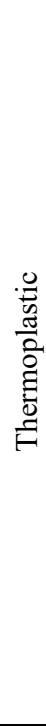 } & $\mathrm{PC}$ & Melt blending & MMT & $\begin{array}{c}\text { Enhanced tensile strength, better } \\
\text { thermal stability. Homogeneous } \\
\text { dispersion of carbon black. }\end{array}$ & & [124] \\
\hline & PMMA & $\begin{array}{l}\text { In situ suspension } \\
\text { polymerization }\end{array}$ & $\begin{array}{l}\text { Methyl } \\
\text { methacrylate } \\
\text { coated }\end{array}$ & $\begin{array}{l}\text { Enhancement of thermal and } \\
\text { mechanical properties. Uses: ultra- } \\
\text { lightweight proppants in the shale oil } \\
\text { and gas exploitation industry. }\end{array}$ & & [125] \\
\hline & PVA & Solution casting & $\begin{array}{l}\text { Polystyrene } \\
\text { sulfonic acid } \\
\text { (PSSA) }\end{array}$ & $\begin{array}{c}\text { Improved dielectric constant and } \\
\text { mechanical properties. } \\
\text { Flexible energy storage device } \\
\text { applications, charge storage capacitors, } \\
\text { electrostriction artificial muscles and } \\
\text { drug delivery. }\end{array}$ & & [122] \\
\hline & Polyimide (PI) & In situ polymerization & $\begin{array}{l}\text { Chloride } \\
\text { modified. } \\
\text { Intercalated } \\
\text { with poly(amic } \\
\text { acid) (PAA) }\end{array}$ & $\begin{array}{l}\text { Higher refractive index. Optical } \\
\text { applications of thin films. }\end{array}$ & & {$[126]$} \\
\hline$\stackrel{\vec{\Phi}}{\vec{E}}$ & PANI & Hydrothermal synthesis & $\begin{array}{l}\text { Manganese } \\
\text { dioxide } \\
(\mathrm{MnO} 2) \\
\end{array}$ & $\begin{array}{l}\text { Excellent electrochemical performance. } \\
\text { Supercapacitor materials uses. }\end{array}$ & I & {$[127]$} \\
\hline $\begin{array}{c}.0 \\
\frac{0}{0} \\
\frac{0}{0} \\
\frac{0}{0} \\
\frac{\pi}{I}\end{array}$ & $\begin{array}{l}\text { Silicone rubber } \\
\text { (SR) based }\end{array}$ & Mechanical mixing & $\begin{array}{l}\text { Ionic liquid- } \\
\text { modified } \\
\text { carbon black }\end{array}$ & $\begin{array}{l}\text { Good piezoresistive properties. Flexible } \\
\text { piezoresistive sensors and wearable } \\
\text { electronic devices. }\end{array}$ & $(\jmath))))(7)$ & {$[128]$} \\
\hline
\end{tabular}




\subsubsection{Graphitic Carbon Nitride}

Graphitic carbon nitride (g-C3N4), in contrast to the other carbon nano fillers, has electron-rich properties, basic surface functionalities and, physical and chemical properties. With a similar structure as graphene, it has been largely investigated in the field of photocatalysis and heterogeneous photocatalysis [129]. Recent studies are also considering using g-C3N4 for proton exchange membranes for fuel cells. The addition of this nanofiller enhances the mechanical properties by increasing the tensile strength of the membranes [129]. GC3N4 has a layered structure, same as graphene, montmorillonite and LDH, however with the advantage of being cheaper. In addition, it is easier and faster to prepare. Studies suggest that it could be a superior alternative to LDH in terms of flame retardancy, improved thermal stability, as well as better mechanical properties and UV shielding [130]. Its incorporation into thermoplastic polyurethane nanocomposites can be a successful alternative to reduce fire hazards [131]. More examples of applications are presented in the Table 10 .

Table 10 - Carbon Nitride combinations with polymer matrixes: processing methods, modification as well as properties and applications.

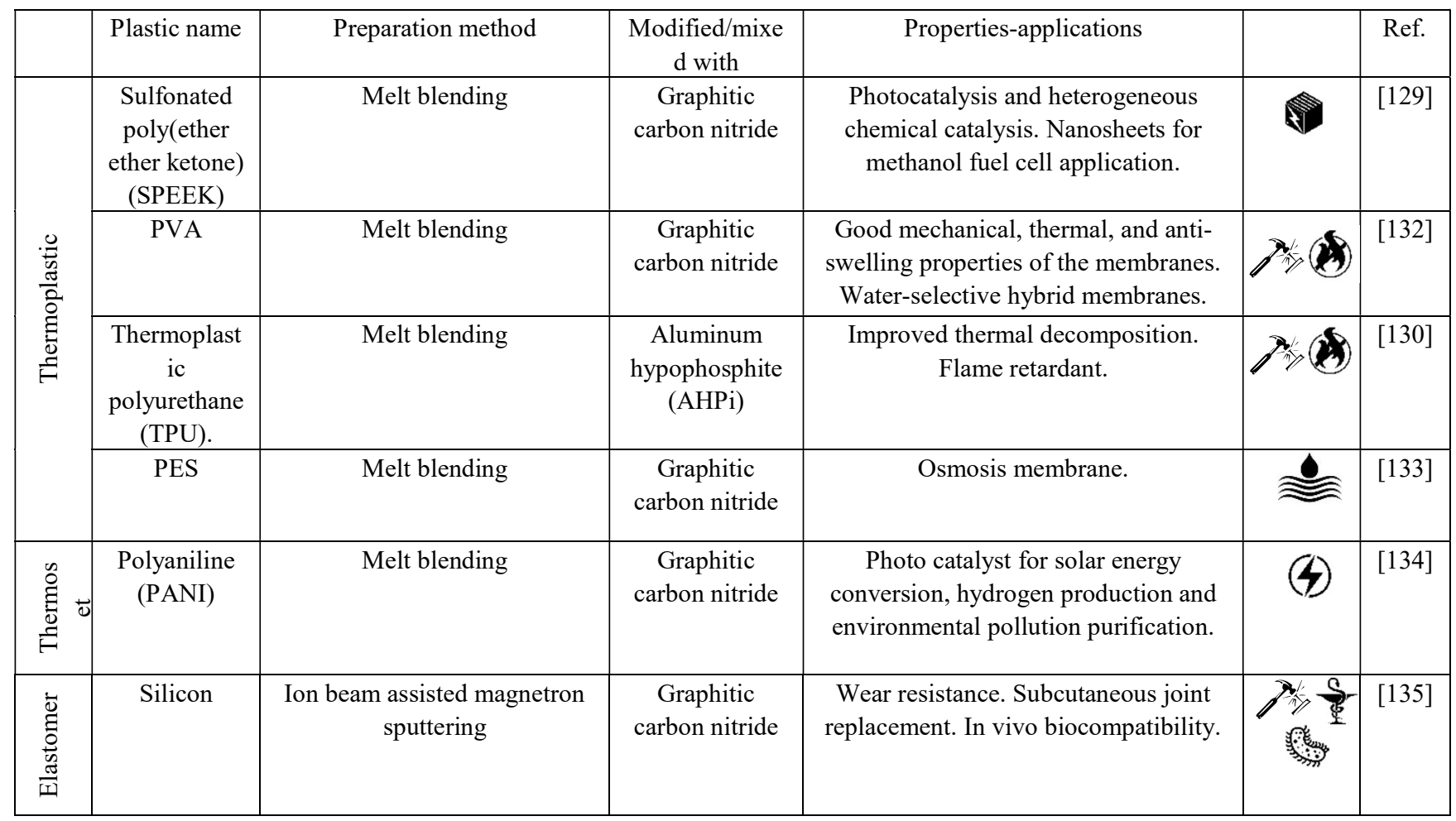

\subsubsection{Nanodiamonds}

Nanodiamond also known as ultra-dispersed diamond or ultrananocrystalline diamond has initially studied in 1960s. This round nanofiller has been very interesting for many industrial applications due to superior hardness, thermal and physical properties [136,137]. Nanodiamond required for industrial applications are produced in large quantities by detonation method. Non-toxicity and biocompatibility of these nanofillers have been confirmed extensively [138]. Therefore, they are one of the ideal candidates for biomedical applications such as reinforcement agents for bone surgery and tissue engineering. Table 11 summarizes the information from the extensive research study for Nanodiamond reinforced polymer matrixes, processing methods, modification agents as well as properties and applications. 
Table 11 - Nanodiamond reinforced polymer matrixes: processing methods, modification as well as properties and applications.

\begin{tabular}{|c|c|c|c|c|c|c|}
\hline & Plastic name & Preparation method & $\begin{array}{l}\text { Modified/mixe } \\
\quad \text { d with }\end{array}$ & Properties-applications & & Ref. \\
\hline \multirow{3}{*}{ 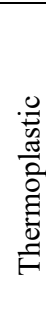 } & $\begin{array}{c}\text { Polyvinyl } \\
\text { alcohol (PVA) }\end{array}$ & electrospinning & - & $\begin{array}{c}\text { Increased tensile modulus and } \\
\text { strength. } \\
\text { biological applications }\end{array}$ & N & [139] \\
\hline & $\begin{array}{c}\text { Poly-L- } \\
\text { (lactide-co-e- } \\
\text { caprolactone) }\end{array}$ & $\begin{array}{l}\text { grafting - from approach of } \\
\text { anionic polymerization }\end{array}$ & - & $\begin{array}{l}\text { Increased elastic modulus. } \\
\text { Tissue engineering }\end{array}$ & 为害 & [140] \\
\hline & PA 66 & In situ reactive extrusion & - & Improved mechanical properties & 8 & [130] \\
\hline \multirow{2}{*}{ 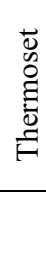 } & Ероху & $\begin{array}{l}\text { liquid-liquid extraction } \\
\text { method }\end{array}$ & $\begin{array}{l}\text { Graphene } \\
\text { oxide }\end{array}$ & $\begin{array}{l}\text { Enhanced mechanical properties, } \\
\text { fracture toughness, and thermal } \\
\text { stability. }\end{array}$ & as & [134] \\
\hline & Epoxy & In situ polymerization & - & $\begin{array}{c}\text { Friction, tribological, and mechanical } \\
\text { properties }\end{array}$ & 象) & [137] \\
\hline 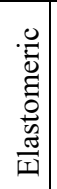 & $\begin{array}{l}\text { Nitrile } \\
\text { butadiene } \\
\text { rubber }\end{array}$ & In situ polymerization & $\begin{array}{l}\text { Mercapto - } \\
\text { terminated } \\
\text { silane agent }\end{array}$ & Improved mechanical properties & vay & [135] \\
\hline
\end{tabular}

\subsubsection{A green approach of carbon nanocomposites}

Applications of CNTs are increasing significantly. However, it is important to considerate the environmental impacts of the CNT inclusion into polymer matrixes. In fact, many studies have shown that they could increase the persistence of polymers in landfills, lakes and surface waters [141]. There are different studies that show both the cytotoxic and non-cytotoxic effects of CNT filled nanocomposites towards different microorganisms with important role in polymer degradation. Their inclusion in matrixes such as PLC, led to a significant decrease of the biodegradability rate [141]. Nevertheless, other hybrid nanocomposites using CNTs have shown improved biodegradability properties [142-144]. CNTs have also shown a significant improvement of Polyhydroxyalkanoates (PHA), improving its Young's modulus, increasing thermal stability and electrical conductivity. Its addition to PHA maintains its biodegradability, however it has a negative effect on the biodegradability rate [66]. The example shown in Table 12, proposes the use of 3-hydroxybutyrate and 3hydroxyhexanoate PHBHHx, a PHA with mechanical properties and biocompatibility. These nanocomposites can be of great interest in the packaging industry, medical, agricultural and many others.

Graphene oxide also has its share of results in terms of biodegradability: in combination with chitosan biopolymer, the presence of the graphene oxide increased the inactivation of the microorganisms in charge of biodegrade them [145]. Combinations with carbon nitride and modified silver chromate nanoparticles, show to be enhance the photocatalytic degradation, an alternative method that is considered an environmentally friendly solution for pollutants decomposition using solar light energy [146]. A review from 2016 collects a variety of examples of biopolymer-graphene nanocomposites together with the available processing methods [147]. In the same context of photocatalytic degradation, carbon nitride has been investigated under combinations with titanium dioxide and cadmium [148]. Graphite has been proven to be degradable in the presence of Penicillium funiculosum in combinations with Poly(3- hydroxybutyrate) (PHB) matrix, despite a higher incubation period [149]. Less information is available about carbon black in terms of biodegradability behavior in polymer nanocomposites with biodegradable matrixes. Table 12 summarizes the information from the research studies of biodegradable nanocomposites using carbon nanofillers. 
Table 12 - Novel research studies of biodegradable nanocomposites using carbon nanofillers.

\begin{tabular}{|c|c|c|c|c|c|c|}
\hline Matrix polymer name & $\begin{array}{l}\text { Carbon } \\
\text { nanofiber } \\
\text { type }\end{array}$ & $\begin{array}{l}\text { Preparation } \\
\text { method }\end{array}$ & $\begin{array}{l}\text { Modified/mixed } \\
\text { with }\end{array}$ & Properties-applications & Field & Ref. \\
\hline PES & Fullerene & $\begin{array}{l}\text { Solution } \\
\text { casting }\end{array}$ & - & $\begin{array}{l}\text { High modulus and impact } \\
\text { resistance. Applications such } \\
\text { as biomarkers, drug delivery } \\
\text { dental applications }\end{array}$ & & [150] \\
\hline PLA & Fullerene & $\begin{array}{l}\text { Electrospinnin } \\
\mathrm{g} \text { and } \\
\text { electrosprayin } \\
\mathrm{g}\end{array}$ & $\begin{array}{l}\text { Zinc Oxide } \\
\quad(\mathrm{ZnO})\end{array}$ & $\begin{array}{l}\text { Photocatalytic and self- } \\
\text { cleaning properties. } \\
\text { Antibacterial activity against } \\
\text { Staphylococcus aureus. }\end{array}$ & & {$[151]$} \\
\hline Polyaniline (PANI) & MWCNTs. & $\begin{array}{c}\text { In situ } \\
\text { polymerizatio } \\
\mathrm{n}\end{array}$ & $\begin{array}{l}\text { Carboxymethyl } \\
\text { cellulose }\end{array}$ & $\begin{array}{c}\text { Enhanced electrical and } \\
\text { electrocatalytic properties. } \\
\text { Used for electroactive } \\
\text { membranes - electrochemical } \\
\text { sensors. }\end{array}$ & & [142] \\
\hline PLLA & MWCNTs. & $\begin{array}{l}\text { Pressure- } \\
\text { induced flow } \\
\text { (PIF) } \\
\text { processing }\end{array}$ & & $\begin{array}{l}\text { Light- weight high-strength } \\
\text { foams with good electrical } \\
\text { conductivity and EMI } \\
\text { shielding properties. }\end{array}$ & & [144] \\
\hline $\begin{array}{l}\text { Carboxymethyl } \\
\text { cellulose (CMC) }\end{array}$ & MWCNTs & $\begin{array}{c}\text { Ultrasonicatio } \\
\mathrm{n}\end{array}$ & - & $\begin{array}{l}\text { Hydrogel showing } \\
\text { biocompatibility using rat } \\
\text { firbroblast cells. Used in } \\
\text { transdermal drug delivery. }\end{array}$ & & [143] \\
\hline $\begin{array}{l}\text { Copolymer of PLA- } \\
\text { PCL (Poly- } \varepsilon- \\
\text { caprolactone) }\end{array}$ & MWCNTs & Boron Nitride & & $\begin{array}{l}\text { Improved damping behaviour } \\
\text { (dissipation of energy inside } \\
\text { the material) with higher } \\
\text { concentrations of CNTs. }\end{array}$ & & {$[152]$} \\
\hline $\begin{array}{l}\text { Cellulose nanofiber } \\
\text { (CNF) }\end{array}$ & MWCNTs & $\begin{array}{l}\text { Vacuum- } \\
\text { assisted self- } \\
\text { assembly } \\
\text { technique }\end{array}$ & - & $\begin{array}{l}\text { Flexible dielectric paper. } \\
\text { Improved mechanical strength. } \\
\text { Used in electronics and } \\
\text { electric power systems. }\end{array}$ & & {$[153]$} \\
\hline PHBHHx & MWCNTs & $\begin{array}{l}\text { Solution } \\
\text { mixing and } \\
\text { evaporation }\end{array}$ & - & $\begin{array}{l}\text { Films for human mesenchymal } \\
\text { stem cell (hMSC) } \\
\text { differentiation. Used in bone } \\
\text { tissue engineering. }\end{array}$ & & {$[154]$} \\
\hline PLA-PBAT & Graphene & Melt - mixing & - & $\begin{array}{c}\text { Enhanced electrical } \\
\text { permittivity, dielectric } \\
\text { properties and electromagnetic } \\
\text { interference shielding } \\
\text { effectiveness. }\end{array}$ & & {$[155]$} \\
\hline Amyloid fibril & Graphene & - & - & $\begin{array}{l}\text { Exceptional mechanical and } \\
\text { electronic properties. } \\
\text { Reversibly change shape } \\
\text { properties towards humidity } \\
\text { stimuli. Uses: biosensors } \\
\text { for quantifying the activity of } \\
\text { enzymes. } \\
\end{array}$ & & {$[156]$} \\
\hline PCL & Graphene & $\begin{array}{c}\text { Solvent } \\
\text { precipitation } \\
\text { technique }\end{array}$ & $\mathrm{Ag}$ & $\begin{array}{l}\text { Increased modulus and } \\
\text { electrical conductivity. } \\
\text { Antibacterial effects, Use in } \\
\text { tissue engineering and fracture } \\
\text { fixation devices. }\end{array}$ & $\pi$ & [157] \\
\hline
\end{tabular}




\begin{tabular}{|c|c|c|c|c|c|c|}
\hline PANI & $\begin{array}{l}\text { Carbon } \\
\text { nitride }\end{array}$ & $\begin{array}{c}\text { In-situ } \\
\text { polymerizatio } \\
\mathrm{n}\end{array}$ & $\mathrm{ZnO}$ & $\begin{array}{l}\text { Improved photocatalytic } \\
\text { properties. }\end{array}$ & $(4)$ & [158] \\
\hline Natural rubber (NR) & Carbon black & & $\begin{array}{c}\text { Cellulose } \\
\text { nanowhiskers }\end{array}$ & $\begin{array}{l}\text { Enhancement of electrical and } \\
\text { mechanical properties. Uses } \\
\text { for EMS, chemical and stress } \\
\text { sensors, actuators, electrostatic } \\
\text { dissipation etc. }\end{array}$ & & [159] \\
\hline $\begin{array}{l}\text { Poly (butylene } \\
\text { succinate) PBS }\end{array}$ & Carbon Black & $\begin{array}{c}\text { Melt } \\
\text { compounding }\end{array}$ & - & $\begin{array}{l}\text { Improved mechanical and } \\
\text { electrical properties. }\end{array}$ & & [160] \\
\hline PLLA & Carbon Black & $\begin{array}{c}\text { Melt } \\
\text { compounding }\end{array}$ & - & $\begin{array}{l}\text { Manipulation of filler network } \\
\text { for decease in the electrical } \\
\text { percolation threshold. }\end{array}$ & & [161] \\
\hline $\begin{array}{l}\text { Polyvinyl alcohol } \\
\text { (PVA) }\end{array}$ & Nanodiamond & $\begin{array}{l}\text { electrospinnin } \\
\mathrm{g}\end{array}$ & & $\begin{array}{c}\text { Increased tensile modulus and } \\
\text { strength. } \\
\text { biological applications }\end{array}$ & & [139] \\
\hline
\end{tabular}

\subsection{Nano Oxides}

Nano oxides are particle shaped nanofillers including Oxygen in their structure. The most commonly used nano oxides are silica $\left(\mathrm{SiO}_{2}\right)$, alumina $\left(\mathrm{Al}_{2} \mathrm{O}_{3}\right)$, and titania $\left(\mathrm{TiO}_{2}\right)$. Due to the hydrophobic properties of the particle surface, these fillers often require heat treatments or chemical reactions in order to facilitate a homogeneous dispersion in the polymer matrix. These nanofillers are used in a broad range of applications. Silica andtitania has been also widely researched for polymer electrolytes for fuel cells (see Table 13). The composite membranes present good ionic conductivity as well as good water retention at low to medium temperatures [162].However, unlike Silica and alumina, titania is used in photocatalytic, optical, and photovoltaic applications [1].A maximum addition of $2 \%$ of silica in food and beverage materials is approved by the FDA, which makes this nanofiller attractive for packaging applications [163]. Its addition to films can improve the tensile strength without compromising the permeability and biodegradability. In many applications, silica has been combined with MMT, since it provides better dispersion and exfoliation in MMT nanocomposites [66,164,165]. Other hybrids combine silica and chitosan, for fuel cells [162], biomaterial for bone regeneration [166],[167], among others. More examples are shown in the Table 13.

Table 13 -Silicon dioxide (SiO2) combinations with polymer matrixes: processing methods, modification as well as properties and applications

\begin{tabular}{|c|c|c|c|c|c|c|}
\hline & Plastic name & Preparation method & $\begin{array}{l}\text { Modified/mix } \\
\text { ed with }\end{array}$ & Properties-applications & Filed & Ref. \\
\hline \multirow{4}{*}{ 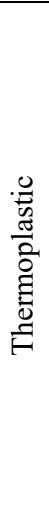 } & PES & $\begin{array}{c}\text { Via sol-gel non- solvent } \\
\text { induced phase } \\
\text { separation } \\
\end{array}$ & $\begin{array}{l}\text { P(PEG- } \\
\text { PDMS- } \\
\text { KH570) }\end{array}$ & $\begin{array}{l}\text { Antifouling performance. Membrane } \\
\text { for water treatment. }\end{array}$ & & [165] \\
\hline & $\begin{array}{l}\text { Poly(lactic-co- } \\
\text { glycolic) acid } \\
\text { (PLGA) }\end{array}$ & Evaporation & $\mathrm{PO}_{2}$ & $\begin{array}{l}\text { Biodegradability and } \\
\text { biocompatibility. Uses: bone } \\
\text { regeneration. }\end{array}$ & & [168] \\
\hline & Polypropylene (PP) & Melt blending & $\begin{array}{l}\text { Graphene } \\
\text { Oxides }\end{array}$ & $\begin{array}{l}\text { Significantly higher tensile and } \\
\text { impact strength. }\end{array}$ & & [169] \\
\hline & $\begin{array}{l}\text { Shape memory } \\
\text { foams (SMF) }\end{array}$ & & $\begin{array}{l}\text { Tungsten, } \\
\text { Aluminium } \\
\text { oxide }\end{array}$ & $\begin{array}{l}\text { Toughness and strain at break. } \\
\text { Microelectromechanical systems, } \\
\text { actuators and biomedical devices and } \\
\text { medical implants. }\end{array}$ & & [170] \\
\hline
\end{tabular}




\begin{tabular}{|c|c|c|c|c|c|c|}
\hline & $\begin{array}{l}\text { Poly(MMA-co- } \\
\text { TMSPMA) }\end{array}$ & $\begin{array}{l}\text { Fragmentation chain } \\
\text { transfer (RAFT) } \\
\text { polymerization }\end{array}$ & - & $\begin{array}{l}\text { Significant improvement of } \\
\text { mechanical properties. Uses for bone } \\
\text { scaffold materials. }\end{array}$ & & [171] \\
\hline$\underset{\Xi}{E}$ & Siloxane polymer & $\begin{array}{l}\text { Organic-inorganic } \\
\text { hybrid method }\end{array}$ & $\begin{array}{c}\mathrm{KH} 570 \\
\mathrm{Al}_{2} \mathrm{O}_{3}-\mathrm{TiO}_{2}\end{array}$ & Films with excellent hydrophobicity. & 1) & {$[172]$} \\
\hline
\end{tabular}

\subsubsection{Alumina}

Alumina nano particles offer high thermal properties, chemical stability, high creep resistance, hardness, strength and, high melting point. In combinations with natural rubber, alumina and kaolinite particles, have been used so far for similar purposes: reinforcement for the mechanical, thermal and electrical properties [173]. Alumina has also been investigated in combinations with graphene for novel electrical and dielectric properties, making this nanocomposites a promising approach for microwave communication of substrates, patch antennas, electromagnetic interference shielding electrostatic dissipation as well as radar cross section reduction for aerospace and automobile sector [174]. More recent investigations suggest the combination of alumina with PEO-PPG blends for polymer electrolytes in zinc batteries, as a replacement of liquid solvents in order to reduce the risk of fire hazard, leakage, waste disposal limitations, and mechanical strength [175]. Table 14 summarizes the Alumina (A12O3) combination with polymer matrixes, their processing methods, modification, properties and applications.

Table 14 - Alumina $\left(\mathrm{Al}_{2} \mathrm{O}_{3}\right)$ combinations with polymer matrixes: processing methods, modification, properties and applications

\begin{tabular}{|c|c|c|c|c|c|c|}
\hline & Plastic name & Preparation method & $\begin{array}{l}\text { Modified/mixe } \\
\text { d with }\end{array}$ & Properties-applications & Field & Ref. \\
\hline \multirow{4}{*}{ 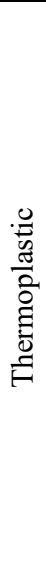 } & $\begin{array}{l}\text { Low-density } \\
\text { polyethylene } \\
\text { (LDPE) as }\end{array}$ & $\begin{array}{l}\text { Pre-mixing and melt- } \\
\text { extrusion }\end{array}$ & - & $\begin{array}{l}\text { Lower DC conductivity. Insulation of } \\
\text { high voltage direct current cables. }\end{array}$ & & $\begin{array}{c}{[176,1} \\
77]\end{array}$ \\
\hline & Polyethylene (PE) o & $\begin{array}{l}\text { Dip-coated and electron } \\
\text { beam irradiation. }\end{array}$ & $\begin{array}{l}\text { (PVDF-HFP) } \\
\text { crosslinker } \\
\text { (TTT) } \\
\end{array}$ & $\begin{array}{l}\text { High thermal resistance and } \\
\text { electrochemical stability. Uses: } \\
\text { llithium secondary battery. }\end{array}$ & & {$[178]$} \\
\hline & PEO & - & $\begin{array}{l}\text { Polypropylene } \\
\text { glycol (PPG) } \\
\text { as } \\
{\left[\mathrm{Zn}\left(\mathrm{CF}_{3} \mathrm{SO}_{3}\right)_{2}\right]}\end{array}$ & $\begin{array}{l}\text { Conductivity enhancement. } \\
\text { Satisfactory electrochemical stability. } \\
\text { Uses: zinc batteries. }\end{array}$ & (4) & {$[175]$} \\
\hline & PVA & $\begin{array}{l}\text { Cyclic freezing/thawing } \\
\text { method. }\end{array}$ & - & $\begin{array}{l}\text { Thermal and water dual-responsive } \\
\text { shape memory properties. Enhanced } \\
\text { mechanical properties. Uses in the } \\
\text { biomedical and aerospace field. }\end{array}$ & & {$[179]$} \\
\hline 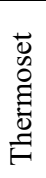 & Epoxy & $\begin{array}{l}\text { Gelcasting, sintering and } \\
\text { vacuum infiltration } \\
\text { methods }\end{array}$ & - & $\begin{array}{l}\text { High strength and thermal } \\
\text { conductivity }\end{array}$ & & {$[180]$} \\
\hline 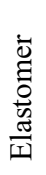 & Silicon rubber & Mechanical mixing & $\begin{array}{l}\text { poly(dopamine } \\
\text { ) (PDA) }\end{array}$ & Enhanced thermal conductivity & & {$[181]$} \\
\hline
\end{tabular}

\subsubsection{Titania}

Titania or Titanium Dioxide is an attractive metal oxide especially due to its photocatalytic properties. It has been widely used in electronic devices because of its low cost and structural stability. Combined with graphene 
oxide, Titania has been investigated for flexible pressure sensors in combination with PVDF, showing good dielectric properties, increased wettability and reduced bio-fouling (accumulation of microorganisms on wetted surfaces) [182]. In the Table 15, other potential applications are listed, such as in textile application with antimicrobial and self-cleaning properties along with the other information collected from the state-of-the-art literatures.

Table 15 - Titanium Dioxide ( $\left.\mathrm{TiO}_{2}\right)$ combinations with polymer matrixes: processing methods, modification, properties and applications

\begin{tabular}{|c|c|c|c|c|c|c|}
\hline & Plastic name & Preparation method & $\begin{array}{l}\text { Modified/mixe } \\
\text { d with }\end{array}$ & Properties-applications & Filed & Ref. \\
\hline \multirow{3}{*}{$\begin{array}{l}0 \\
0 \\
0 \\
\frac{\pi}{0} \\
0 \\
0 \\
0 \\
0 \\
D\end{array}$} & Nylon & - & $\begin{array}{l}\mathrm{ZnO} \\
\text { Cotton }\end{array}$ & $\begin{array}{c}\text { Fabric with good abrasion resistance, } \\
\text { dye ability and comfort Antimicrobial } \\
\text { properties of hospital clothing. }\end{array}$ & 瓷, & [183] \\
\hline & PBT & Melt blending & - & $\begin{array}{l}\text { Self- cleaning properties under UV-A } \\
\text { radiation. Possibility of producing } \\
\text { textile products. }\end{array}$ & & {$[184]$} \\
\hline & PEO & Solution casting & $\mathrm{NaClO}_{4}$ & Sodium ion batteries. & 4 & {$[185]$} \\
\hline 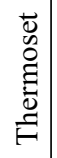 & Epoxy & Solution blending & $\mathrm{Ag}$ & $\begin{array}{c}\text { Used as bactericidal surface coating in } \\
\text { industrial or healthcare. }\end{array}$ & & [186] \\
\hline 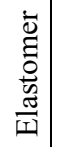 & Silicone rubber & $\begin{array}{l}\text { Ultrasonic treatment and } \\
\text { mechanical mixing }\end{array}$ & - & $\begin{array}{l}\text { Highly transparent LED packaging } \\
\text { materials. }\end{array}$ & & [187] \\
\hline
\end{tabular}

\subsubsection{Magnesia}

Similar to Titanium Dioxide, Magnesium Oxide or Magnesia possess features as photocatalytic and antimicrobial activity. Non-toxicity, biocompatibility, thermal and electrical insulation, UV blocking ability are also among other interesting properties of this nanofiller. These features have made $\mathrm{MgO}$ attractive for applications such as bactericide, packaging material (in combinations with chitosan), as well as material for toxic waste remediation [188]. Recent studies propose using MgO in LDPE blends as novel insulation material for high voltage distribution of renewable energy [189]. A uniformly dispersed coating could enhance the thermal degradation significantly, by increasing it with approximately $100{ }^{\circ} \mathrm{C}$. Table 16 presente $4 \mathrm{~s}$ the summaries of the research study of the state-of-the-art literatures about Magnesium oxide $(\mathrm{MgO})$ about the polymer matrixes that can be combined with $\mathrm{MgO}$, the processing methods of the combinations, modification agents of the naonfiller along with their important properties and applications.

Table 16 - Magnesium oxide (MgO) combinations with polymer matrixes: processing methods, modification, properties and applications

\begin{tabular}{|c|c|c|c|c|c|}
\hline Matrix polymer name & $\begin{array}{c}\text { Preparation } \\
\text { method }\end{array}$ & $\begin{array}{c}\text { Modified/mixe } \\
\text { d with }\end{array}$ & Properties-applications & Field & Ref. \\
\hline LDPE & Melt compounding & Vermiculite & $\begin{array}{l}\text { Long-term antibacterial effect. } \\
\text { Biocompatible. Uses in health care and } \\
\text { medical products, syringe, catheters, } \\
\text { pharmaceutical bottles, PE bags, health foils } \\
\text { etc. }\end{array}$ & 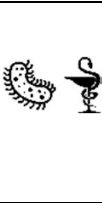 & {$[190]$} \\
\hline
\end{tabular}




\begin{tabular}{|c|c|c|c|c|c|}
\hline Polyindole (PIn) & - & $\mathrm{TiO}_{2}$ & $\begin{array}{l}\text { Electrically conductive; excellent optical } \\
\text { and electrical properties. Uses in solar cells, } \\
\text { gas sensors, and short-wavelength light- } \\
\text { emitting devices rechargeable batteries etc. }\end{array}$ & $\begin{array}{l}(4)+4)) \\
(\Delta))\end{array}$ & [191] \\
\hline Polypyrrole & $\begin{array}{c}\text { In-situ } \\
\text { polymerization }\end{array}$ & $\begin{array}{l}\text { Ammonium } \\
\text { Persulphate }\end{array}$ & $\begin{array}{c}\text { Reduced DC conductivity. Uses in } \\
\text { insulating material for electronic insulation: } \\
\text { Printed Circuit Boards (PCB), capacitors, } \\
\text { precoat for PCB holes, etc. }\end{array}$ & & [192] \\
\hline $\begin{array}{c}\text { Thermoplastic } \\
\text { polyurethane (TPU) }\end{array}$ & $\begin{array}{l}\text { Pulsed laser } \\
\text { ablation }\end{array}$ & - & $\begin{array}{l}\text { Photoluminescent properties. Green } \\
\text { photoluminescence emission. Uses in } \\
\text { biomedical or photovoltaic devices. }\end{array}$ & & [193] \\
\hline $\begin{array}{l}\text { CTAB-modified } \\
\text { geopolymer matrix }\end{array}$ & $\begin{array}{l}\text { Chemical } \\
\text { precipitation } \\
\text { method }[10]\end{array}$ & $\mathrm{Cu}_{2} \mathrm{O}$ & $\begin{array}{l}\text { Removal of methylene blue (MB) dye dyes } \\
\text { from water by adsorption and } \\
\text { photodegradation. Removal of organic } \\
\text { pollutants from water or atmosphere. }\end{array}$ & & [194] \\
\hline
\end{tabular}

\subsubsection{Zinc oxide}

Food and Drug Administration (FDA) has recognized $\mathrm{ZnO}$ as safe enough to be used as additive in amplification of foods [179]. In the area of nanocomposites, Zinc Oxide has been used as an antibacterial agent, UV absorber, and vulcanizing agent for elastomers [8]. New studies propose using bacterial cellulose biopolymer, in combination with $\mathrm{ZnO}$ to enhance the antibacterial properties, and transforming the nanocomposite into an excellent dressing for burn wounds [195]. A state-of-the-art summary of the research study about $\mathrm{ZnO}$ is presented in the Table 17.

Table 17 - Zinc oxide (ZnO) combinations with polymer matrixes: processing methods, modification, properties and applications

\begin{tabular}{|c|c|c|c|c|c|c|}
\hline & $\begin{array}{l}\text { Matrix polymer } \\
\text { name }\end{array}$ & $\begin{array}{l}\text { Preparation } \\
\text { method }\end{array}$ & $\begin{array}{l}\text { Modified/mix } \\
\text { ed with }\end{array}$ & Properties-applications & Filed & Ref. \\
\hline \multirow{3}{*}{ 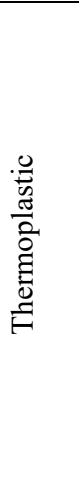 } & $\begin{array}{l}\text { Linear low } \\
\text { density } \\
\text { polyethylene } \\
\text { (LLDPE) }\end{array}$ & Melt blending & - & $\begin{array}{l}\text { No production of space charges and } \\
\text { enhanced DC breakdown strength. } \\
\text { Uses: cable insulation application }\end{array}$ & & [196] \\
\hline & PLLA & $\begin{array}{l}\text { Simple casting } \\
\text { method. }\end{array}$ & $\begin{array}{l}\text { Hydroxyapatit } \\
\text { e (HA) }\end{array}$ & $\begin{array}{l}\text { Orthopaedic tissue engineering } \\
\text { applications. Biomaterial for bone } \\
\text { implantation. }\end{array}$ & & [197] \\
\hline & $\mathrm{PVC}$ & $\begin{array}{l}\text { Ultrasonic } \\
\text { irradiation and } \\
\text { solution } \\
\text { dispersion }\end{array}$ & PVA & $\begin{array}{l}\text { Environmentally friendly } \\
\text { manufacturing of nanocomposite films. } \\
\text { Biomedical applications for wound } \\
\text { healing devices, transparent electronics, } \\
\text { light emitting devices, etc. }\end{array}$ & & {$[179]$} \\
\hline$\underset{\stackrel{0}{\Xi}}{\stackrel{0}{0}}$ & Epoxy & $\begin{array}{l}\text { Mechanical } \\
\text { mixing }\end{array}$ & - & $\begin{array}{l}\text { Avoid dielectric breakdown or tracking } \\
\text { failure in electronic devices. }\end{array}$ & & [198] \\
\hline 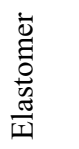 & $\begin{array}{l}\text { Polydimethylsilox } \\
\text { ane (PDMS) }\end{array}$ & CVT synthesis & - & $\begin{array}{l}\text { Sensors for biomedical devices, optical } \\
\text { displays }\end{array}$ & & [199] \\
\hline
\end{tabular}




\subsubsection{A green approach of biodegradable nano oxide composites}

Nano oxides show degradability properties combined with biodegradable polymer matrixes when buried underground. In blends with poly butylene succinate (PBS) - chitosan (CS), both Silica and Alumina have shown signs of degradability, even more compared to graphene particles. However there are signs of lower weight loss compared to the pure PBS-chitosan blend [200]. $\mathrm{TiO}_{2}$ and polypropylene PP nanocomposites show efficient photocatalytic degradation behavior [201], as well as in blends with $\epsilon$-caprolactone / DL-lactide ( $\epsilon$ CL/DL-LA) copolymerspoly [202]. Table 18 summarizes the state-of-the-art information from the research studies of biodegradable nanocomposites using nano oxide.

Table 18 - Novel research studies of biodegradable nanocomposites using nano oxide.

\begin{tabular}{|c|c|c|c|c|c|c|}
\hline Matrix polymer name & $\begin{array}{l}\text { Carbon } \\
\text { nanofiber } \\
\text { type }\end{array}$ & $\begin{array}{l}\text { Preparation } \\
\text { method }\end{array}$ & $\begin{array}{l}\text { Modified/mix } \\
\text { ed with }\end{array}$ & Properties-applications & Field & Ref. \\
\hline PVA & Silica $\left(\mathrm{SiO}_{2}\right)$ & $\begin{array}{c}\text { In situ } \\
\text { polymerization }\end{array}$ & Chitosan & $\begin{array}{l}\text { Excellent mechanical } \\
\text { properties, low permeability } \\
\text { for oxygen and water. Uses: } \\
\text { food packaging. } \\
\end{array}$ & & {$[163]$} \\
\hline Polybutadiene rubber & Silica $\left(\mathrm{SiO}_{2}\right)$ & $\begin{array}{c}\text { In situ } \\
\text { polymerization }\end{array}$ & Chitosan & $\begin{array}{l}\text { Improved flexibility, } \\
\text { toughness, and thermal } \\
\text { insulation. Uses in wound } \\
\text { dressing, drug delivery, and } \\
\text { tissue engineering. }\end{array}$ & & {$[203]$} \\
\hline PLA & $\begin{array}{l}\text { Zeolites } \\
\left(\mathrm{NaAlO}_{2}\right. \\
\left.\mathrm{SiO}_{2}\right)\end{array}$ & Melt blending & - & $\begin{array}{l}\text { Lower water and oxygen } \\
\text { permeability. Improved } \\
\text { mechanical properties and } \\
\text { antimicrobial activity. Uses in } \\
\text { food packaging. }\end{array}$ & & {$[204]$} \\
\hline Guar gum & Silica $\left(\mathrm{SiO}_{2}\right)$ & $\begin{array}{l}\text { In-situ } \\
\text { deposited } \\
\text { through sol-gel } \\
\text { technique }\end{array}$ & - & $\begin{array}{l}\text { Absorption capacity of } \\
\text { cationic dyes/metal ions, } \\
\text { cationic malachite green from } \\
\text { mixture of dye solutions. Uses } \\
\text { in wastewater management. }\end{array}$ & & {$[205]$} \\
\hline $\begin{array}{l}\text { e-caprolactone } \\
\text { (PCL) }\end{array}$ & Silica $\left(\mathrm{SiO}_{2}\right)$ & Crosslinking & - & $\begin{array}{l}\text { Shape memory polymer, UV } \\
\text { triggered. Improved } \\
\text { mechanical properties. Uses in } \\
\text { biomedical applications. }\end{array}$ & & {$[206]$} \\
\hline $\begin{array}{c}\text { Cellulose acetate } \\
\text { (CA) }\end{array}$ & $\begin{array}{l}\text { Alumina } \\
\left(\mathrm{Al}_{2} \mathrm{O}_{3}\right)\end{array}$ & Melt blending & - & $\begin{array}{l}\text { Improved dielectric properties. } \\
\text { Uses in electronic devices, e.g. } \\
\text { embedded passives. }\end{array}$ & & {$[207]$} \\
\hline Cellulose & $\begin{array}{l}\text { Titanium } \\
\text { Dioxide } \\
\left(\mathrm{TiO}_{2}\right)\end{array}$ & $\begin{array}{l}\text { Phase inversion } \\
\text { technique. }\end{array}$ & - & $\begin{array}{l}\text { Photocatalytic performance for } \\
\text { phenol degradation in aqueous } \\
\text { solution. Used for wastewater } \\
\text { treatment. }\end{array}$ & & {$[208]$} \\
\hline $\begin{array}{l}\text { Starch, amino acid } \\
\text { (lysine), } \\
\text { polypropylene glycol } \\
\text { (PPG) }\end{array}$ & $\begin{array}{l}\text { Zinc oxide } \\
\quad(\mathrm{ZnO})\end{array}$ & Solution casting & - & $\begin{array}{l}\text { Increased thermal stability and } \\
\text { mechanical properties. Shape } \\
\text { memory properties. Uses: food } \\
\text { packaging }\end{array}$ & & {$[209]$} \\
\hline PLLA & $\begin{array}{l}\text { Magnesium } \\
\text { oxide }(\mathrm{MgO})\end{array}$ & Casting method & - & $\begin{array}{l}\text { Improved osteoblast adhesion } \\
\text { while maintaining mechanical } \\
\text { properties. Orthopedic tissue } \\
\text { engineering applications. }\end{array}$ & $\sqrt{5}$ & {$[197]$} \\
\hline
\end{tabular}




\subsection{Hydroxides}

Hydroxide nanofillers have been intensively investigated for the replacement of toxic flame-retardant additives, since they have the capacity to reduce the toxicity of the fumes emitted to low or inexistent. The applications where it is of main concern are in energy storage devices (lithium batteries) as well as in electrical and communication cables, furniture, etc. The most common hydroxides fire retardant additives are Aluminum Hydroxide (ATH) and Magnesium Hydroxide. Boehmite and Layered Double Hydroxides (LDHs) increase thermal stability in polymer nanocomposites, however their efficiency is not as good as in the aforementioned hydroxides [210]. The sections below will discuss the most common hydroxide nanofillers with examples of different applications and alternative combinations.

\subsubsection{Aluminum Hydroxide}

Aluminum Hydroxide is the most extensively used as fire retardant agent on the market due to its low costs [8] . Their incorporation within polymer blends not only increase the flame retardancy but also reduces the smoke emissions toxicity [211]. Other advantages of incorporating Aluminum Hydroxide in polymers include higher toughness, low density and corrosion resistance. It is common to see Aluminum Hydroxide used in PCV and PE wires, as well as in combinations with silicones, nanoclays and boron compounds [211]. Recent studies propose a more efficient alternative to Aluminum Hydroxide, by incorporating Magnesium-AluminumZirconium Hydroxide into poly(4-vinylpyridine-co-butyl methacrylate) (PVBM) matrixes, for the preparation of composite coatings [210]. Table 19 presents the important information about Aluminum hydroxide, its possible combinations with polymer matrixes, processing methods, modification, properties and applications.

Table 19 -Aluminum hydroxide $\left(\mathrm{Al}(\mathrm{OH})_{3}\right)$ combinations with polymer matrixes: processing methods, modification , properties and applications

\begin{tabular}{|c|c|c|c|c|c|}
\hline $\begin{array}{l}\text { Matrix polymer } \\
\text { name }\end{array}$ & Preparation method & $\begin{array}{l}\text { Modified/mixed } \\
\text { with }\end{array}$ & Properties-applications & Filed & Ref. \\
\hline Cellulose aerogel & $\begin{array}{l}\text { In-situ sol-gel } \\
\text { synthesis }\end{array}$ & AmimC & $\begin{array}{l}\text { Improved improve flame retardancy. } \\
\text { Uses in tissue engineering, waste-water } \\
\text { treatment, thermal insulation, etc. } \\
\text { Biocompatibility, biodegradability. }\end{array}$ & & [212] \\
\hline AAm and AMPS & $\begin{array}{c}\text { In situ } \\
\text { copolymerization }\end{array}$ & - & $\begin{array}{l}\text { Hydrogel with good mechanical } \\
\text { properties and self-healing properties. } \\
\text { Biomedical applications in healing tissue } \\
\text { engineering. }\end{array}$ & & [213] \\
\hline $\begin{array}{l}\text { Poly(1,4-butylene } \\
\text { adipate) (PBA) }\end{array}$ & Solution mixing & $\begin{array}{l}\text { (layered double } \\
\text { hydroxide } \\
\text { (PBA/m-LDH)) m- } \\
\text { LDH }\end{array}$ & $\begin{array}{c}\text { Improved crystallization behaviour. } \\
\text { Biodegradable. }\end{array}$ & & {$[214]$} \\
\hline $\begin{array}{l}\text { Polyurethane foam } \\
\text { (PU) }\end{array}$ & Solution mixing & - & $\begin{array}{l}\text { Improved flame retarding. Uses in } \\
\text { nanocoatings and conformal coatings, } \\
\text { alternative to halogenated systems. }\end{array}$ & & {$[215]$} \\
\hline
\end{tabular}

\subsubsection{Magnesium hydroxide}

Magnesium Hydroxide (MH) has the same working principle as Aluminum Hydroxide, however it has been far less used in polymer blends. Due to the higher degradation temperatures (approximately $100{ }^{\circ} \mathrm{C}$ higher than $\left.\left(\mathrm{Al}(\mathrm{OH})_{3}\right)\right)$, it performs better when incorporated in polymers with higher thermal stability [8]. Despite its low cost, the required content and mass to deliver the desired fire retardancy properties, often leads to poor dispersion and aggregation. Therefore, a large number of studies have focused on improving their dispersion in the polymer matrix by modifying the MH nanoparticles, e.g. with oorganic phosphate [216]. Table 20 presents the state-of-the-art information collected about Magnesium hydroxide. 
Table 20 - Magnesium hydroxide $\left(\mathrm{Mg}(\mathrm{OH})_{2}\right)$ combinations with polymer matrixes: processing methods, modification, properties and applications

\begin{tabular}{|c|c|c|c|c|}
\hline $\begin{array}{c}\text { Matrix polymer } \\
\text { name }\end{array}$ & $\begin{array}{c}\text { Preparation } \\
\text { method }\end{array}$ & $\begin{array}{c}\text { Modified/mixed } \\
\text { with }\end{array}$ & Properties-applications & Ref. \\
\hline ABS & - & Organic phosphate & $\begin{array}{c}\text { Improved flammability due to enhancement of } \\
\text { the strength of the char layer. Uses in car } \\
\text { industry, pipes, telephone parts etc. }\end{array}$ & [216] \\
\hline PE & - & $\begin{array}{c}\text { Hexyl and } \\
\text { phosphoric moieties }\end{array}$ & Better thermal stability and surface modification \\
atyano scale. & $\begin{array}{c}\text { Organcoclay } \\
\text { (Organically } \\
\text { modified } \\
\text { montmorillonite) }\end{array}$ & Enhanced thermal and fire retardant properties. & \\
\hline
\end{tabular}

\subsubsection{Boehmite}

Boehmite is Aluminium Oxide Hydroxide $[\mathrm{AlO}(\mathrm{OH})]$, generally used as nanofillers for polymers to enhance mechanical properties and other novel properties such as corrosion and wear resistance coatings [219] suppressing flammability of PU foams, proton exchange membranes, smart hydrogels etc. [220]. The preparation methods for Boehmite can be divided in four groups: in situ synthesis, template synthesis, melt intercalation (melt blending) techniques and intercalation of polymer from solution [221]. Table 18 presents examples of some relevant properties and applications that these nanofillers can offer to different polymer matrixes. More details about the combinations of matrixes and Boehmite can be found in a review study published in $2018:$ [222]

Table 21 -Boehmite $[\mathrm{AlO}(\mathrm{OH})]$ combinations with polymer matrixes: processing methods, modification , properties and applications

\begin{tabular}{|c|c|c|c|c|c|}
\hline $\begin{array}{l}\text { Matrix polymer } \\
\text { name }\end{array}$ & Preparation method & $\begin{array}{l}\text { Modified/mixed } \\
\text { with }\end{array}$ & Properties-applications & & Ref. \\
\hline PLA & Melt processing & PCL & $\begin{array}{l}\text { Improved mechanical, thermal, and rheological } \\
\text { properties. Biodegradability. Medical } \\
\text { applications, packaging, agriculture. }\end{array}$ & & {$[223]$} \\
\hline PMMA & In situ polymerization & $\begin{array}{l}\text { Silane modified } \\
\text { nano-boehmite }\end{array}$ & $\begin{array}{l}\text { Improved thermal properties. Excellent copper } \\
\text { absorption in aqueous solutions. }\end{array}$ & & [221] \\
\hline $\begin{array}{l}\text { Siloxane-modified } \\
\text { methacrylic }\end{array}$ & In situ polymerization & - & $\begin{array}{l}\text { Better sun light protection, hydrophobicity and } \\
\text { durability. Used for stone materials coatings } \\
\text { (monuments, artifacts, etc.). }\end{array}$ & (1) & {$[224]$} \\
\hline Silicone rubber & Melt compounding & - & $\begin{array}{l}\text { Better erosion, arcing resistance and tracking. } \\
\text { Used for outdoor insulators. }\end{array}$ & (4) & [225] \\
\hline
\end{tabular}

\subsubsection{Layered Double Hydroxide}

Layered Double Hydroxides (LDHs) are inorganic clays containing positively charged metal hydroxides together with multivalent anions, achieving thus, neutrality. These compounds are $\mathrm{Zn} / \mathrm{Al}, \mathrm{Mn} / \mathrm{Al}, \mathrm{Fe} / \mathrm{Al}, \mathrm{Li} / \mathrm{Al}$ and $\mathrm{Mg} / \mathrm{Al}$. The highly tunable properties, low cost, thermal stability and chemical versatility make them attractive for hybrid nanocomposites using carbon nanofillers: CNTs, CNFs, and graphene [226]. These hybrids present unique properties, particularly for thermal stability. For instance, graphene and LDH nanocomposites are used as magnets, supercapacitors, water treatment, and medical applications. They are 
mostly incorporated in different polymers in order to improve fire retardancy properties and to enhance graphene's properties in this direction [226]. Table 22 compiles the information about the polymer matrixes, processing methods of composites, modification agents of the LDHs nanofillers, the composite properties and applications for LDHs.

Table 22 - LDHs combinations with polymer matrixes: processing methods, modification, properties and applications

\begin{tabular}{|c|c|c|c|c|c|c|}
\hline $\begin{array}{l}\text { Matrix polymer } \\
\text { name }\end{array}$ & LDH type & $\begin{array}{l}\text { Preparation } \\
\text { method }\end{array}$ & $\begin{array}{l}\text { Modified/mix } \\
\text { ed with }\end{array}$ & Properties-applications & & Ref. \\
\hline $\begin{array}{l}\text { Polyethylene } \\
\text { terephthalate } \\
\qquad(\mathrm{PET})\end{array}$ & $\mathrm{MgAl}$ & $\begin{array}{c}\text { In situ } \\
\text { polymerization }\end{array}$ & $\begin{array}{l}\text { Modified with } \\
\text { sulfanilic acid } \\
\text { salt (SAS) }\end{array}$ & $\begin{array}{l}\text { Improved thermomechanical } \\
\text { properties, crystallization behaviour } \\
\text { and gas barrier properties. Uses in } \\
\text { electronic-packing materials, food } \\
\text { and beverage packaging. }\end{array}$ & & {$[227]$} \\
\hline PP & $\mathrm{MgAl}$ & $\begin{array}{l}\text { One-step melt } \\
\text { mixing }\end{array}$ & $\begin{array}{l}\text { Ethylene vinyl } \\
\text { acetate } \\
\text { copolymer } \\
\text { (EVA) }\end{array}$ & $\begin{array}{l}\text { Increased storage modulus and } \\
\text { improved thermal stability. }\end{array}$ & & {$[228]$} \\
\hline $\mathrm{PA}$ & $\mathrm{ZnAl}$ & $\begin{array}{c}\text { In situ } \\
\text { polymerization }\end{array}$ & - & $\begin{array}{l}\text { Thin film membranes with increased } \\
\text { hydrophobicity for removal of } \\
\text { natural organic matter from drinking } \\
\text { water. }\end{array}$ & (1) & [229] \\
\hline PS & $\mathrm{Li} / \mathrm{Al}$ & $\begin{array}{c}\text { In situ } \\
\text { polymerization }\end{array}$ & - & $\begin{array}{l}\text { Improved chemical and mechanical } \\
\text { stability in water. Defluorination of } \\
\text { water }\end{array}$ & & {$[174]$} \\
\hline
\end{tabular}

\subsubsection{A green approach of biodegradable hydroxide nanocomposites.}

Table 23 presents different examples of LDH included biodegradable matrixes. In addition to the most commonly investigated biodegradable polymers, other ecofriendly materials like poly(hydroxyalkanoate)s (PHAs), have also been presented due to their excellent biodegradability, biocompatibility as well as good mechanical properties. A variation of this material, poly(3-hydroxybutyrate-co-4-hydroxybutyrate) $(\mathrm{P}(3,4) \mathrm{HB})$ improves the initial high crystallinity and lowers the melting point $\left(<170^{\circ} \mathrm{C}\right)$ which improves the initial brittleness, and the thermal stability and processing temperatures. With the addition of CoAl LDH, the thermomechanical properties can be further improved [230]. Other types of LDH have also shown to improve the mechanical properties: e.g. Mg/Al-LDH for PBS [231], Zn3Al -LDH for PLA [232]. Boehmite nanoplatelets have not only shown improvement of mechanical properties, but also increased the biodegradability rate of biobased Poly(propylene sebacate) (PPSe) [233].

Table 23 - Novel research studies of biodegradable nanocomposites using nano hydroxide.

\begin{tabular}{|c|c|c|c|c|c|c|}
\hline $\begin{array}{l}\text { Matrix polymer } \\
\text { name }\end{array}$ & $\begin{array}{l}\text { Nano- } \\
\text { hydroxide } \\
\text { type }\end{array}$ & $\begin{array}{l}\text { Preparation } \\
\text { method }\end{array}$ & $\begin{array}{l}\text { Modified/mix } \\
\text { ed with }\end{array}$ & Properties-applications & Field & Ref. \\
\hline $\begin{array}{l}\text { Magnetic alginate } \\
\text { beads (LDH- } \\
\text { nMABs) }\end{array}$ & $\begin{array}{c}\mathrm{Mg}-\mathrm{Al}-\mathrm{LDH} \\
\text { nanoflake }\end{array}$ & - & - & $\begin{array}{l}\text { Biodegradable, hydrophobic and } \\
\text { magnetic sensitivity. Used for } \\
\text { water fluoride removal. }\end{array}$ & & [234] \\
\hline PLA & $\begin{array}{c}\text { Stearate- } \\
\text { Zn3Al LDH }\end{array}$ & $\begin{array}{c}\text { Solution casting } \\
\text { method }\end{array}$ & - & $\begin{array}{c}\text { Significant improvement for } \\
\text { elongation at break as well as an } \\
\text { increased rate of degradation in } \\
\text { soil. }\end{array}$ & & [232] \\
\hline PBS & $\mathrm{Mg} / \mathrm{Al}-\mathrm{LDH}$ & $\begin{array}{c}\text { In situ } \\
\text { polymerization }\end{array}$ & - & Superior mechanical properties. & & [231] \\
\hline
\end{tabular}




\begin{tabular}{|c|c|c|c|c|c|c|}
\hline $\mathrm{P}(3,4) \mathrm{HB}$ & CoAl LDH & $\begin{array}{c}\text { Melt } \\
\text { intercalation }\end{array}$ & $\begin{array}{l}\text { Modified with } \\
\text { sodium } \\
\text { stearate }\end{array}$ & $\begin{array}{l}\text { Better thermal stability, } \\
\text { enhanced storage modulus. } \\
\text { Plastic in food packaging } \\
\text { industry, tissue engineering, } \\
\text { agricultural applications. }\end{array}$ & & [230] \\
\hline PPSe & $\begin{array}{c}\text { Boehmite } \\
(\mathrm{BM}) \\
\text { nanoplatelets }\end{array}$ & $\begin{array}{c}\text { In situ } \\
\text { polymerization }\end{array}$ & - & $\begin{array}{l}\text { Enhanced mechanical properties } \\
\text { and biodegradability. Shape } \\
\text { memory properties at body } \\
\text { temperature. } \\
\text { Biomedical applications, such as } \\
\text { stents, in human body }\end{array}$ & & [233] \\
\hline $\begin{array}{c}\text { Blends of PLA and } \\
\text { PCL }\end{array}$ & $\begin{array}{c}\text { Boehmite } \\
\text { (BAI) } \\
\text { nanoparticles }\end{array}$ & $\begin{array}{c}\text { In situ } \\
\text { polymerization }\end{array}$ & - & $\begin{array}{l}\text { Enhanced mechanical properties. } \\
\text { Uses in medicine, engineering, } \\
\text { packaging industry, and } \\
\text { agriculture. }\end{array}$ & & [223] \\
\hline
\end{tabular}

\subsection{Carbides}

Nano carbides are compounds of carbon and metal or semimetal. They present high melting temperatures and are usually used as refractory materials. Due to the similarities in the crystalline structure with diamond of silicon and boron carbide, they present the highest hardness, providing the polymer matrix better wear resistance [1]. The most commonly used nano carbides are silicon $(\mathrm{SiC})$, boron $\left(\mathrm{B}_{4} \mathrm{C}\right)$, titanium $(\mathrm{TiC})$ and zirconium carbide $(\mathrm{ZrC})$. $\mathrm{SiC}$ has high mechanical thermal and electrical properties, and they exhibit great biocompatibility and its hardness makes it attractive for erosion resistance coatings[235], [236]. As can be noticed from the examples in the Table 22, it has been used for improving the dielectric properties, however they are used in hydrogels for water decontamination [236]. $\mathrm{B}_{4} \mathrm{C}$ showing similar properties as $\mathrm{SiC}$, has been also intensively used to improve wear resistance in polymers. Additionally, $\mathrm{B}_{4} \mathrm{C}$ has neutron absorbing properties rendering it suitable for nuclear applications [1]. In contrast to other nanofillers, Carbides are not commonly included in different polymer matrixes; however their applications have been explored for different coatings to improve wear resistance (PU, epoxy, see Table 22). TiC has been used is electrochemically inert and due to catalytic activity towards $\mathrm{I} 3$ reduction, it has been investigated in combinations with poly $(3,4-$ ethylenedioxythiophene) (PEDOT) for dye-sensitized solar cell applications [237]. With a similar effect as graphene, in combinations with PANI, it can improve the performance of electrode material for supercapacitors [238]. More examples are shown in Table 24 below.

Table 24- Silicon carbide $(\mathrm{SiC})$, boron carbide $\left(\mathrm{B}_{4} \mathrm{C}\right)$, and titanium carbide $(\mathrm{TiC})$ in combinations with polymer matrixes: processing methods, modification, properties and applications.

\begin{tabular}{|c|c|c|c|c|c|}
\hline Matrix polymer name & $\begin{array}{c}\text { Carbide } \\
\text { type }\end{array}$ & $\begin{array}{l}\text { Preparation } \\
\text { method }\end{array}$ & $\begin{array}{l}\text { Modified/mix } \\
\text { ed with }\end{array}$ & Properties-applications & Ref. \\
\hline $\begin{array}{c}\text { Polycarbosilane (PCS) } \\
\& \\
\text { PVP }\end{array}$ & $\mathrm{SiC}$ & $\begin{array}{c}\text { Melt } \\
\text { blending }\end{array}$ & $\begin{array}{l}\text { Layered } \\
\text { carbon }\end{array}$ & $\begin{array}{l}\text { Excellent dielectric loss properties } \\
\text { tunable dielectric and broadband } \\
\text { electromagnetic wave absorption. } \\
\text { Used for electromagnetic shielding } \\
\text { in wireless devices. }\end{array}$ & [239] \\
\hline PS & $\mathrm{SiC}$ & $\begin{array}{c}\text { Melt } \\
\text { blending }\end{array}$ & - & $\begin{array}{l}\text { Enhanced thermal and optical } \\
\text { properties. Used in microwave } \\
\text { dielectrics, power energy storage } \\
\text { materials, }\end{array}$ & [240] \\
\hline $\begin{array}{c}\text { Cross-linked } \\
\text { polyethylene (XLPE) }\end{array}$ & $\mathrm{SiC}$ & $\begin{array}{c}\text { Melt } \\
\text { blending }\end{array}$ & - & $\begin{array}{c}\text { Improved DC breakdown strength, } \\
\text { increased real and imaginary } \\
\text { permittivity, suppression of space } \\
\text { charge }\end{array}$ & [241] \\
\hline
\end{tabular}




\begin{tabular}{|c|c|c|c|c|c|}
\hline Polyurethane (PU) & $\mathrm{B}_{4} \mathrm{C}$ & $\begin{array}{l}\text { Mechanical } \\
\text { mixing }\end{array}$ & - & $\begin{array}{l}\text { Enhanced erosion wear resistance in } \\
\text { silt erosion conditions. Used for } \\
\text { coating in order to avoid erosion in } \\
\text { turbine blades. }\end{array}$ & [235] \\
\hline Epoxy & $\mathrm{B}_{4} \mathrm{C}$ & $\begin{array}{l}\text { Mechanical } \\
\text { mixing }\end{array}$ & $\mathrm{PbO}$ & $\begin{array}{l}\text { Improved mechanical and thermal } \\
\text { properties by ultrasonic irradiation. }\end{array}$ & [242] \\
\hline Epoxy & $\mathrm{B}_{4} \mathrm{C}$ & $\begin{array}{l}\text { Mechanical } \\
\text { mixing }\end{array}$ & Clay & $\begin{array}{l}\text { Increased Young's modulus, } \\
\text { decrease of tensile strength, better } \\
\text { thermal stability. Used for neutron } \\
\text { shielding application. }\end{array}$ & [243] \\
\hline $\begin{array}{l}\text { Polyphenylene sulfide } \\
\text { (PPS) }\end{array}$ & $\mathrm{TiC}$ & $\begin{array}{c}\text { In situ } \\
\text { polymerizati } \\
\text { on }\end{array}$ & - & $\begin{array}{l}\text { Enhanced tribological and } \\
\text { mechanical properties. }\end{array}$ & [244] \\
\hline Polyimide (PI) & $\mathrm{TiC}$ & $\begin{array}{l}\text { In situ } \\
\text { polymerizati } \\
\text { on }\end{array}$ & PVP & $\begin{array}{l}\text { Enhanced mechanical properties } \\
\text { and electrical breakdown strength. }\end{array}$ & [245] \\
\hline Ppolypyrrole (PPy) & $\mathrm{TiC}$ & $\begin{array}{l}\text { In situ } \\
\text { polymerizati } \\
\text { on }\end{array}$ & PVA & $\begin{array}{c}\text { Enhanced mechanical properties. } \\
\text { High-power supercapacitor } \\
\text { material. }\end{array}$ & [246] \\
\hline $\begin{array}{l}\text { Regenerated bacterial } \\
\text { cellulose (RBC) }\end{array}$ & $\mathrm{TiC}$ & - & - & $\begin{array}{l}\text { Enhanced bactericidal activity. } \\
\text { Used for wound healing and tissue } \\
\text { regeneration applications. }\end{array}$ & [247] \\
\hline Polypyrrole (PPy) & $\mathrm{TiC}$ & $\begin{array}{l}\text { Heterogene } \\
\text { ous } \\
\text { nucleation } \\
\text { process. }\end{array}$ & - & $\begin{array}{l}\text { High-rate (up to } 400 \text { C-rate) charge- } \\
\text { discharge capability and cycling } \\
\text { stability of Li-ion batteries. }\end{array}$ & [248] \\
\hline
\end{tabular}

\subsubsection{A green approach of biodegradable carbide filled nanocomposites}

Table 25 collects two relevant studies for biodegradable versions of nano carbide reinforced nanocomposites. No studies were found for biodegradable options for boron and titanium carbide nanoparticles.

Table 25 - Novel research studies of biodegradable nanocomposites using carbides.

\begin{tabular}{|c|c|c|c|c|c|c|}
\hline $\begin{array}{l}\text { Matrix polymer } \\
\text { name }\end{array}$ & $\begin{array}{c}\text { Carbide } \\
\text { nanofiber type }\end{array}$ & $\begin{array}{l}\text { Preparation } \\
\text { method }\end{array}$ & $\begin{array}{l}\text { Modified/mixe } \\
\text { d with }\end{array}$ & Properties-applications & Field & Ref. \\
\hline PLA & $\mathrm{SiC}$ & $\begin{array}{l}\text { Solution- } \\
\text { blending } \\
\text { method }\end{array}$ & $\begin{array}{c}\text { Surface- } \\
\text { modified SiC } \\
(\mathrm{S}-\mathrm{SiC}) \\
\end{array}$ & $\begin{array}{l}\text { Enhanced impact strength; } \\
\text { more ductile fracture. }\end{array}$ & & {$[249]$} \\
\hline $\begin{array}{c}\text { Gum karaya }(\mathrm{GK}) \\
\text { hydrogel grafted } \\
\text { with PAA }\end{array}$ & $\mathrm{SiC}$ & $\begin{array}{l}\text { In situ graft } \\
\text { copolymerizat } \\
\text { ion method }\end{array}$ & & $\begin{array}{l}\text { Increased strength and } \\
\text { adsorption rate capacity of } \\
\text { cationic dyes from } \\
\text { contaminated water. }\end{array}$ & & {$[236]$} \\
\hline
\end{tabular}

\subsection{Organic nanofillers}

Many industries have started to search for alternatives to synthetic nanocomposites by using natural nanofillers that can provide polymers not only features such as enhanced mechanical properties, light weight, low cost, but also the advantages of recyclability, biocompatibility, renewability and non-hazardous properties [250]. The important information about some of the most important organic nanofillers are collected for the recent literatures and presented in the sections below. 


\subsubsection{Cellulose}

Cellulose, a linear macromolecule, is the most abundant polymer on Earth. Cellulose originates in plants, algae, certain type of bacteria, tunicates, etc. In addition, recent research provide methods of using waste paper for the extraction of cellulose nanofibers [251]. This bio-based nanofiller can be used as reinforcement for multiple polymer matrixes in order to achieve higher stiffness, strength, and biodegradability. The process of extraction of cellulosic fiber, either mechanically or chemically induced, produces nanomaterials called cellulose nanofibrils (CNFs) and cellulose nanocrystals (CNCs) respectively. While CNFs present high aspect ratio flexible filaments, CNCs occur as rod-like acicular nanoparticles [252]. Cellulose nanocrystals (CNCs) have been recently proposed also as an alternative to synthetic nanofillers such as carbon nanotubes. CNCs have hydrophilic properties, which makes them ideal to combine with hydrophobic polymer matrixes. Some of the applications of these fillers include pharmaceutical, biomedical implants, drug delivery, batteries, super capacitors, and antimicrobial membranes, etc. Recent studies have started to focus also on the light scattering properties of CNCs [253]. The study presented in [250] provides a summary of almost forty different polymer matrixes $\mathrm{CNC}$ based nanocomposites and, the corresponding rheological properties. The important information on $\mathrm{CNCs}$ from the recent literatures are collected and presented in Table 26.

In order to produce CNCs and CNFs filled composites, melt processing approaches such as extrusion, hot pressing, and injection molding have been widely used. . As CNFs present higher probability of entanglement of the former in such processing methods, a reduced percolation threshold could be expected. Polymers such as poly(ethylene oxide) (PEO), poly(ethylene glycol) (PEG), Polylactic acid (PLA) as well as polypropylene (PP) have been extensively used in combination with these nanofillers. Different processing techniques of other polymer matrixes are presented in the following study: [252]. However, alternative processing such as casting and evaporation have proven to create the most efficient and well-performing cellulosic nanocomposites [252].

Table 26 - Cellulose nano-crystals (CNC) combinations with polymer matrixes: processing methods, modification, properties and applications

\begin{tabular}{|c|c|c|c|c|c|}
\hline $\begin{array}{l}\text { Matrix polymer } \\
\text { name }\end{array}$ & Preparation method & $\begin{array}{l}\text { Modified/mixed } \\
\text { with }\end{array}$ & Properties-applications & & Ref. \\
\hline $\begin{array}{c}\text { Poly(soybean } \\
\text { acrylate) }(\mathrm{P} 1) \text { and } \\
\text { poly(soybean } \\
\text { methacrylate) }\end{array}$ & $\begin{array}{l}\text { Solution mixing } \\
\text { method }\end{array}$ & $\begin{array}{l}\text { hydroxyl }-\mathrm{OH} \\
\text { and carboxyl } \\
\text {-COOH groups } \\
\text { via thiolene }\end{array}$ & $\begin{array}{c}\text { Stimuli responsive material (water-triggered } \\
\text { modulus switching). Applications: } \\
\text { packaging. }\end{array}$ & 8 & [254] \\
\hline $\begin{array}{l}\text { Triblock copolymer } \\
\text { (PEO-PPO-PEO) }\end{array}$ & Melt extrusion & - & $\begin{array}{l}\text { Thermal stability, improved mechanical } \\
\text { properties, hydrophobic properties. }\end{array}$ & 28 & [255] \\
\hline $\begin{array}{l}\text { Polydimethylsiloxan } \\
\text { e (PDMS) }\end{array}$ & $\begin{array}{c}\text { In situ } \\
\text { polymerization }\end{array}$ & PVA & $\begin{array}{c}\text { Light Management in Optoelectronic } \\
\text { Devices } \\
\text { Organic light-emitting diodes } \\
\text { Light absorption enhancement in thin-film } \\
\text { solar cells. }\end{array}$ & 00 & [253] \\
\hline NR in latex form & Hand lay-up method & - & Higher tensile strength & 08 & $\begin{array}{l}{[256,} \\
257]\end{array}$ \\
\hline
\end{tabular}

\subsubsection{Nanolignin}

While cellulose is an insoluble substance constituting the cell walls of vegetable fibers, lignin is an organic substance that binds the cell fibers and vessel elements in side woods. Lignin nano particles has been used to reinforce natural rubber or synthetic polymers in order to increase thermal stability, strength, Young's modulus [258], and anti-oxidant and microbicidal properties [259]. Recent research proposes using nano-ligning for partially replacing carbon black in natural rubbers to improve their mechanical and thermal properties, thermo- 
oxidative stability and providing a faster vulcanization. The benefit of these nanofillers over carbon black is that lignin is less dense, non-electrically conductive and lighter in color [260]. More information about Nanolignin is resented in Table 27.

Table 27 - Nano-lignin in combinations with polymer matrixes: processing methods, modification, properties and applications

\begin{tabular}{|c|c|c|c|c|c|}
\hline Matrix polymer name & $\begin{array}{l}\text { Preparation } \\
\text { method }\end{array}$ & $\begin{array}{l}\text { Modified/mixed } \\
\text { with }\end{array}$ & Properties-applications & & Ref. \\
\hline $\begin{array}{l}\text { Hydrogels: (graphene, } \\
\text { polyacrylic, } 1 \text { amide-based, } \\
\text { lignosulfonate, pectin etc.) }\end{array}$ & & - & $\begin{array}{c}\text { Removal of various pollutants from } \\
\text { water due to high absorption properties. }\end{array}$ & & [261] \\
\hline Natural rubber & $\begin{array}{l}\text { Co-precipitation } \\
\text { of colloidal } \\
\text { lignin-cationic } \\
\text { polyelectrolyte } \\
\text { complexes and } \\
\text { rubber latex }\end{array}$ & $\begin{array}{c}\text { Poly } \\
\text { (diallyldimethyla } \\
\text { mmonium } \\
\text { chloride) } \\
\text { (PDADMAC) }\end{array}$ & $\begin{array}{c}\text { Accelerated vulcanization. Enhanced } \\
\text { thermal stability and mechanical } \\
\text { properties. }\end{array}$ & $\sin$ & [260] \\
\hline
\end{tabular}

\subsubsection{Chitin}

Chitin is another abundant polymer found in nature, which makes it ideal for many biomedical applications. Chitosan is a deacetylated product of chitin and used in combination with other polymer matrixes. The corresponding composites present better mechanical strength, water absorption capacity, biocompatibility, biodegradability, etc. Moreover, extensive research studies have been done in using these nanofillers in tissue engineering, replacing or restoring defective tissue [262]. In order to improve their antibacterial properties, modifications with most effective antimicrobial agents such as silver nanoparticles have also been proposed [263]. Xylan chains have also been added to chitosan nanocomposites, due to their antibacterial and antioxidant properties [264]. Table 28 presents the Chitin's possible combinations with polymer matrixes, the processing methods, modification, properties and applications.

Table 28 - Chitin in combinations with polymer matrixes: processing methods, modification, properties and applications

\begin{tabular}{|c|c|c|c|c|}
\hline $\begin{array}{c}\text { Matrix polymer } \\
\text { name }\end{array}$ & Preparation method & $\begin{array}{c}\text { Modified/mixed } \\
\text { with }\end{array}$ & Properties-applications & Ref. \\
\hline $\begin{array}{c}\text { Sodium hydrogen } \\
\text { carbonate }\end{array}$ & Magnetic stirring & $\begin{array}{c}\text { PLGA } \\
\text { nanoparticles }\end{array}$ & $\begin{array}{c}\text { Higher elastic modulus. Thermosensitive } \\
\text { hydrogels. Antibacterial, antifungal, } \\
\text { mucoadhesive, analgesic haemostatic, } \\
\text { biodegradable, biocompatible properties. }\end{array}$ & $\begin{array}{c}{[265} \\
]\end{array}$ \\
\hline PVA hydrogel & $\begin{array}{c}\text { Solution casting } \\
\text { method.using } \\
\text { gluteraldehyde as a } \\
\text { crosslinking agent }\end{array}$ & $\mathrm{ZnO}$ & $\begin{array}{c}\text { Increased antimicrobial activity (ZnO). } \\
\text { Tensile strength depending on cross linking } \\
\text { apent. } \\
\text { Applications: packaging sheets, membrane } \\
\text { filtration, biomedical material for } \\
\text { controlled release, tissue regeneration etc. }\end{array}$ & $\begin{array}{c}{[266} \\
]\end{array}$ \\
\hline
\end{tabular}

\subsubsection{Nanostarch}

Starch nanocrystals can be found abundantly in plants and it has been used for the preparation of biocompatible films. Nano starch has antibacterial properties against Staphylococcus aureus and Pseudomonas aeruginosa. In addition, Nanostarch fillers shows other remarkable properties such as swelling reduction, barrier and blood compatibility properties which makes it ideal for biomedical applications such as wound 
healing [267]. The use of nanostarch is currently limited due to the high cost of their extraction and processing. Preparation methods with different matrixes have been successful in the case of NR or styrene butadiene rubber latex, , a powder form for commercial sale has not been yet achieved to be used for melt processing techniques [8]. Table 29 presents the summary of the current research studies on the Nanostarch.

Table 29 - Starch nanocrystals combinations with polymer matrixes: processing methods, modification, properties and applications

\begin{tabular}{|c|c|c|c|c|c|}
\hline $\begin{array}{l}\text { Matrix polymer } \\
\text { name }\end{array}$ & Preparation method & $\begin{array}{l}\text { Modified/mixed } \\
\text { with }\end{array}$ & Properties-applications & & Ref. \\
\hline PVP & $\begin{array}{c}\text { Solution casting } \\
\text { method. }\end{array}$ & - & $\begin{array}{l}\text { higher tensile strength and Young's } \\
\text { modulus } \\
\text { Reduced oxygen permeability, antibacterial } \\
\text { activity. Wound dressing applications. }\end{array}$ & & {$[267]$} \\
\hline $\begin{array}{l}\text { Plasticized starch } \\
\text { matrix }\end{array}$ & $\begin{array}{l}\text { Solvent-casting } \\
\text { method. }\end{array}$ & - & $\begin{array}{l}\text { Better mechanical properties. Reduced } \\
\text { moisture absorbtion. Hydrophilic } \\
\text { properties. Shape memory properties. } \\
\text { Biomedical application. }\end{array}$ & S & {$[268]$} \\
\hline $\begin{array}{l}\text { Plasticized starch } \\
\text { matrix }\end{array}$ & $\begin{array}{l}\text { Solvent-casting } \\
\text { method. }\end{array}$ & - & $\begin{array}{l}\text { Enhanced mechanical properties. UV } \\
\text { resistance. Thermal resistance. } \\
\text { Applications: sustainable packaging. }\end{array}$ & $\sin$ & {$[269]$} \\
\hline
\end{tabular}

\subsection{Other nanofillers}

Many other nanofillers have captured the attention in recent research, e.g. Polyhedral oligomeric silsesquioxane (POSS), which provides high thermal stability, flame retardancy, better mechanical properties, low dielectric properties, etc. It can be part of green nanocomposites when combined with polymers such as cellulose, providing improved wettability, better UV aging and UV resistance/shielding [270]; It has been part of novel composites membranes combined with chitosan, used for guided bone tissue regeneration [166]. Recent combinations include PA matrix, for improved thermal stability and surface hydrophobicity [271], PMMA for tuning properties of transparency [272]; Hybrid copolymers of N-isopropyl acrylamide (NIPAm) for thermally-responsive hydrogel behavior [273], etc. Silver is another widely used nanoparticle, generally preferred due to its antimicrobial properties against bacteria, fungi and viruses. Surprisingly, in the form of nanoparticles, presents even better properties than particles with larger diameter [274]. Furthermore, Gold nanoparticles therapeutics, sensor, therapeutic agents, drug delivery in biological and medical applications, imaging, electronics, etc. [275]. Table 30 presents some applications of the nanofiller reinforced composites.

Table 30 -polymer nanocomposites filled with other nanofillers: processing methods, modification, properties and applications

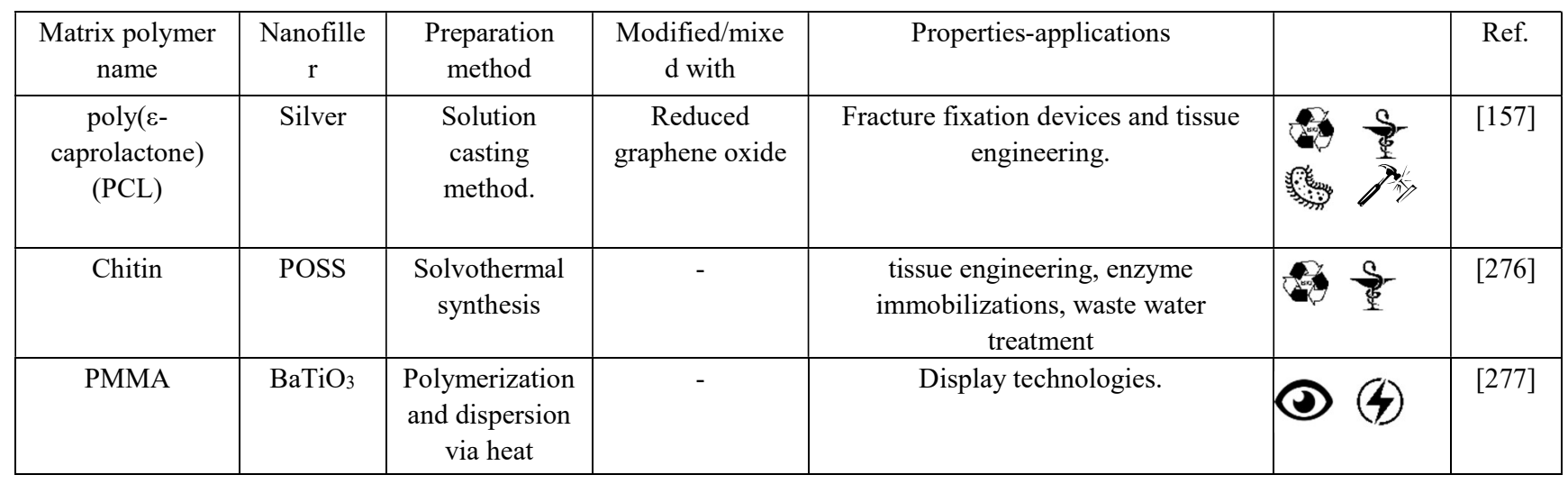




\begin{tabular}{|c|c|c|c|c|c|c|}
\hline & treatment & & & & \\
\hline $\begin{array}{c}\text { Poly(dimethylsil } \\
\text { oxane) }\end{array}$ & Gold & $\begin{array}{c}\text { Thermal } \\
\text { polymerization }\end{array}$ & & $\begin{array}{c}\text { Microfluidic and optofluidic } \\
\text { applications }\end{array}$ & (278] \\
\hline
\end{tabular}

\subsubsection{A green approach of biodegradable nanocomposites with other type of fillers.}

Table 31 presents some of different types of nanofillers that have not yet been described in the previous sections but has high potential as biodegradable nanocomposites. The selected ones focus mainly on medical applications such as bone tissue engineering and cancer cell growth inhibition since there is an increased interest and demand of medical solutions to bone and cancer problems. These studies also present biodegradable and recyclable properties in line with the scope of this paper.

Table 31 - Novel research studies of biodegradable nanocomposites using other type of fillers.

\begin{tabular}{|c|c|c|c|c|c|c|}
\hline $\begin{array}{l}\text { Matrix polymer } \\
\text { name }\end{array}$ & Nanofiller type & $\begin{array}{l}\text { Preparation } \\
\text { method }\end{array}$ & $\begin{array}{l}\text { Modified/mixe } \\
\text { d with }\end{array}$ & Properties-applications & Field & Ref. \\
\hline $\begin{array}{l}\text { Poly(butylene } \\
\text { succinate-co- } \\
\text { terephthalate) } \\
\text { (PBST) } \\
\text { nanocomposites }\end{array}$ & $\begin{array}{l}\text { Fibrous attapulgite } \\
\text { (ATP- magnesium } \\
\text { aluminum silicate } \\
\text { clay) }\end{array}$ & $\begin{array}{c}\text { In situ } \\
\text { polymerization }\end{array}$ & - & $\begin{array}{c}\text { Enhanced mechanical } \\
\text { properties compared with } \\
\text { only silica nanoparticles. }\end{array}$ & & $\begin{array}{c}{[279} \\
]\end{array}$ \\
\hline $\begin{array}{c}\text { Gellan and xanthan } \\
\text { polymers }\end{array}$ & $\begin{array}{c}\text { Bioglass } \\
\text { nanoparticles } \\
(\mathrm{SiO} 2-\mathrm{CaO}-\mathrm{P} 2 \mathrm{O} 5)\end{array}$ & $\begin{array}{c}\text { In situ } \\
\text { polymerization }\end{array}$ & - & $\begin{array}{l}\text { Tunable bone tissue } \\
\text { engineering scaffolds in } \\
\text { terms of mechanical } \\
\text { stiffness, bioactivity and } \\
\text { bacteriostatic properties. }\end{array}$ & & $\begin{array}{c}{[280} \\
]\end{array}$ \\
\hline PANI & $\begin{array}{l}\text { Porous silicon } \\
\text { nanoparti- } \\
\text { cles (PSiNPs) }\end{array}$ & $\begin{array}{c}\text { Surface } \\
\text { initiated } \\
\text { polymeriza- } \\
\text { tion }\end{array}$ & - & $\begin{array}{l}\text { Superior biodegradability } \\
\text { and biocompatibility in } \\
\text { vitro and in vivo. Uses: } \\
\text { cancer cell growth } \\
\text { inhibition. }\end{array}$ & & $\begin{array}{c}{[281} \\
]\end{array}$ \\
\hline $\begin{array}{l}\text { Poly(propylene } \\
\text { fumarate) (PPF) }\end{array}$ & $\begin{array}{l}\text { Tungsten disulfide } \\
\text { nanotubes }\end{array}$ & $\begin{array}{c}\text { In situ } \\
\text { polymerization }\end{array}$ & $\begin{array}{l}\text { SWCNTs and } \\
\text { MWCNTs }\end{array}$ & $\begin{array}{l}\text { Better mechanical } \\
\text { properties. Used for bone } \\
\text { tissue engineering. }\end{array}$ & & $\begin{array}{c}{[282} \\
]\end{array}$ \\
\hline PBST & $\begin{array}{l}\text { Fibrous attapulgite } \\
\text { (ATP) }\end{array}$ & $\begin{array}{c}\text { In situ } \\
\text { polymerization }\end{array}$ & - & $\begin{array}{c}\text { Enhanced mechanical } \\
\text { properties. }\end{array}$ & & $\begin{array}{c}{[279} \\
]\end{array}$ \\
\hline $\begin{array}{c}\text { Poly(butylene } \\
\text { succinate) }(\mathrm{PBSu})\end{array}$ & $\begin{array}{c}\text { Strontium } \\
\text { hydroxyapatite } \\
\text { nanorods }\end{array}$ & $\begin{array}{c}\text { In situ } \\
\text { polymerization }\end{array}$ & - & $\begin{array}{l}\text { Enhanced mechanical } \\
\text { properties, enzymatic } \\
\text { hydrolysis and apatite } \\
\text { formation. Osteoblast } \\
\text { compatibility. Tissue } \\
\text { engineering applications. }\end{array}$ & & $\begin{array}{c}{[283} \\
]\end{array}$ \\
\hline
\end{tabular}

\section{Summary and discussion}

The paper presents a comprehensive list of nanofillers, list of compatible polymer matrixes for each of the naofillers, novel polymeric nanocomposites and their preparation methods etc. from an application in advanced application view point. While nanofillers could enhance different properties in the polymeric matrix and produce multifunctional materials, they critically affected by the effectiveness of preparation method. Acquiring a proper dispersion and distribution of fillers define the properties and application of the produced 
composites. There are different parameters in non-uniform dispersion of nanofillers such as high interfacial energy, high aspect ratio, incompatibility of the hydrophilic fibers and hydrophobic nature of polymer matrixes, etc. Moreover, a high concentration of fillers inside the matrix has a negative impact on micro structural defects. Most nanofillers presented in this paper could enhance one or a group of properties including mechanical, thermal, electrical, and tribological properties. The different properties and other relevant notes regarding each nanofillers group are discussed below.

Nanoclays increase the tensile, flexural modulus and yield strength of the polymeric composites. However, they reduce the maximum strain of thermoplastics, while increasing the elastic modulus, strength, and toughness of thermosets. Within elastomer matrixes, nanoclays decrease the relaxation rate butimprove aging properties. It is also noteworthy to mention that they could act as an alternative to carbon black since they exhibit similar properties in lower contents. However, the particular influence of nanoclays is theirimproving influence on the thermal stability of the polymer matrix, making them an excellent choice for many fireretardant applications. Nevertheless, studies that have been conducted on medical applications acknowledge them an attractive option of tissue engineering materials, drug delivery devices, and hydrogel with antimicrobial activity, etc.

Carbon, the second studied group of nanofillers presented a big impact on the mechanical properties of the polymer matrix by increasing toughness, young modulus and tensile strength of the corresponding composites. Carbon black as the oldest member of this group has been known for more than a century, however, the new members of this group attracted science and industry in the recent decades. CNTs are the most studies nanofillers in the recent years, however, new studies show that graphene can also provide a comparable enhancement in mechanical properties. One of the most important properties of carbonic nanofillers is their electrical properties. This property makes these fillers suitable for polymers with shape memory properties and various applications in electronic industries. In addition, the extraordinary thermal properties of Graphene fillers have already made them indispensable in future microelectronics devices. Nanodiamonds exhibiting the superior properties of diamond in nanoscale have also proved themselves influential in enhancement of mechanical, tribological, thermal properties.

Ceramic nanoparticles such as nano oxides provide comparable thermal properties as nanoclays. Membranes containing Silicon Doxides can be also used for water treatment. Other films containing the same filler have also exhibited hydrophobic properties. Titanium dioxide, presents self-cleaning properties which makes them attractive for biomedical applications, hospital clothing, and surface coatings for medical devices etc. Moreover, hydroxide nanoparticles have been extensively studied in the last decade. Although this paper presented three examples, there are many other hydroxides used for nanocomposites, such as: yttrium hydroxide $\mathrm{Y}(\mathrm{OH})_{3}$, layered double hydroxide $(\mathrm{LDH})$ of different metals, etc. Most of them, are used for fire retardancy applications. There are also novel research studies that use boehmite for other applications such as sun light protection coatings, outdoor insulators, etc. In addition, carbides are used in coatings for high temperature applications, since they have very high melt temperatures. Silicon carbide is used to increase wear resistance, while boron carbide has been studies for neutron absorption nanocomposites, ideal for nuclear applications.

Organic nanofillers are of huge interest at present due to their biocompatibility and their potential for medical applications. An good number of studies have been conducted in the recent past to increase the biodegradability of the polymer composites to eliminate their negative environmental impacts. An example is the recent discovery of Ideonella sakaiensis 201-F6 bacterium, which has the ability to use PET as its main carbon and energy source for growth, transforming this polymer into a possible biodegradable alternative [284]. PET is one of the most popular synthetic polymers for the production of containers for liquids and foods as well as textiles. Although recyclable, this plastic it has been accumulating, and its resistance to biodegradability has raised serious concerns due to its effect on the growing risk of fauna and flora, mainly in marine environments. This paper gives examples of multiples biodegradable nanocomposite alternatives: PLA, PHB, aromatic copolyesters such as PBAT, polyethers, PA, PU, chitin, chitosan, PC, and PHA, In addition, there are many other biodegradable polymers as green alternative for future polymer nanocomposites such as 
PLC, PGA, PVL, Poly(-decalactone), Polyhydroxyvalerate (PHV), Poly(-malic acid) (PMLA), Poly(ortho esters) (POE), Poly(amide-enamines), Polyanhydrides, Polysaccharides (naturally occurring starches and cellulose), Polycyanoacrylates, Polyketals, Polyphosphoesters, Polyacetals, Polyphosphazenes (PPHOS), Poly(imino-carbonates), Poly(1,4-dioxan-2-one) (PDO) [285].

\section{Conclusions}

Polymeric nanocomposites are one of the most interesting and promising topic in the area of polymer science, chemistry, nanotechnology, etc. In fact, the advent of the nanofillers opened new doors to new applications and technologies not exited before. Moreover, the new composites are replacing many traditional materials in different industrial sections. The multifunctional properties introduced by these novel materials are key features in many advanced products. Industrial applications from medical micro components to aerospace products are redefining their design to benefit from the development of nanocomposites. However, it seems that many achievements might have been missed among these huge amount of data and research studies. This review papers endeavored to categorize some part of this significant progress with respect to their applications in the different industrial sections and give a guideline for the easy selection of nanocomposites for industrial applications. The most prominent nanofillers are introduced based on their geometrical characteristics and enhancement features. Their applications in the different polymers and preparation methods are discussed. However, application of many of these composites might have undesired negative environmental impacts. To produce and dispose nanofillers and nanocomposites in environmentally safe ways are vital. Therefore, this paper focused particularly on green and biocompatible composites to allow the readers to find alternatives to conventional nanocomposites for providing minimal environmental impact in connections with the applications of nanocomposites into industrial products.

In conclusion, new technologies are emerging and processing nanomaterials and composites showing novel properties and improved performances. Nanocomposites are potential materials to meet the emerging demands arising from scientific and technologic advances. Processing methods for different types of nanocomposites are available, but some of these provide challenges which give the opportunities for further researchers and developments. A good number of applications of nanocomposites already exist, but more widespread applications of nanocomposites are possible in the future provided some technical challenges are overcome; health, safety and environmental concerns related to nanocomposites are addressed. The release of nanoparticles into the environment is a big concern for health and safety. Hence there is an increasing need for research for the emission control of nanocomposites and nanoparticles. The green or environmentally friendly nano composites seem to be the future of nanomaterials and their world-wide applications in the indusial products. So the future research should focus on the development of green nanofillers, nanocomposites and their novel applications.

\section{REFERENCES}

Rallini M, Kenny JM. Nanofillers in Polymers. Elsevier Inc.; 2016. doi:10.1016/B978-0-323-44353-1.00003-8

Ajayan PM, Schadler LS, Braun P V. Nanocomposite Science and Technology. Wiley; 2003.

Gupta RK, Kennel E, Kim KJ. Polymer Nanocomposites Handbook. Taylor \& Francis; 2009.

Zhang Z, Han Y, Li T, Wang T, Gao X, Liang Q, et al. Polyaniline/montmorillonite nanocomposites as an effective flame retardant and smoke suppressant for polystyrene. Synth Met 2016;221:28-38. doi:10.1016/j.synthmet.2016.10.009. Anwar Z, Kausar A, Muhammad B. Polymer and Graphite-
Derived Nanofiller Composite: An Overview of Functional Applications. Polym - Plast Technol Eng 2016;55:1765-84. doi:10.1080/03602559.2016.1163598.

[6] Tang C, Chen N, Hu X. Conducting Polymer Hybrids. 2017. doi:10.1007/978-3-319-46458-9.

[7] Fujii K, Nakagaito AN, Takagi H. Effect of Acid Treatment on Mechanical Performance of Polyvinyl Alcohol/Halloysite Nanocomposites. Key Eng Mater 2014;627:113-6. doi:10.4028/www.scientific.net/KEM.627.113.

[8] Rothon R. Fillers for Polymer Applications 2017:489. doi:10.1007/978-3-319-28117-9.

[9] Liu Y, Lv H, Lan X, Leng J, Du S. Review of electro-active shape-memory polymer composite. Compos Sci Technol 2009;69:2064-8. doi:10.1016/j.compscitech.2008.08.016.

[10] Zhang D, Chang H, Liu R. Humidity-Sensing Properties of 
One-Step Hydrothermally Synthesized Tin Dioxide-Decorated Graphene Nanocomposite on Polyimide Substrate. J Electron Mater 2016;45:4275-81. doi:10.1007/s11664-016-4630-2.

[11] Kausar A, Ur Rahman A. Effect of graphene nanoplatelet addition on properties of thermo-responsive shape memory polyurethane-based nanocomposite. Fullerenes Nanotub Carbon Nanostructures 2016;24:235-42. doi:10.1080/1536383X.2016.1144592.

[12] Cai W, Huang Y, Wang D, Liu C, Zhang Y. Piezoresistive behavior of graphene nanoplatelets/carbon black/silicone rubber nanocomposite. J Appl Polym Sci 2014;131:1-6. doi:10.1002/app.39778.

[13] Yuvaraj H, Jae-Jin S. Manufacturing polymer nanocomposites 2016:29-65.

[14] Bari SS, Chatterjee A, Mishra S. Biodegradable polymer nanocomposites: An overview. Polym Rev 2016;56:287-328. doi:10.1080/15583724.2015.1118123.

[15] Detellier C, Letaief S. Kaolinite-polymer nanocomposites. vol. 5. 2nd ed. Elsevier Ltd.; 2013. doi:10.1016/B978-0-08-0982588.00022-5

[16] Çelı M, Önal M, Erref O. Preparation and Characterization of Intercalated Polymethacrylamide / Na - Montmorillonite Nanocomposites Preparation and Characterization of Intercalated 2017;1325. doi:10.1080/10601320600653806.

[17] Kotal M, Bhowmick AK. Polymer nanocomposites from modified clays: Recent advances and challenges. Prog Polym Sci 2015;51:127-87. doi:10.1016/j.progpolymsci.2015.10.001.

[18] Jia YX, Sun LJ, Chen XG, An M, Sang XM. A Review on Polymer/Kaolinite Nanocomposites. Adv Mater Res 2013;750752:213-6. doi:10.4028/www.scientific.net/AMR.750-752.213.

[19] Cabedo L, Villanueva MP, Lagar??n JM, Gim??nez E. Development and characterization of unmodified kaolinite/EVOH nanocomposites by melt compounding. Appl Clay Sci 2017;135:300-6. doi:10.1016/j.clay.2016.10.008.

[20] Cabedo L, Giménez E, Lagaron JM, Gavara R, Saura JJ. Development of EVOH-kaolinite nanocomposites. Polymer (Guildf) 2004;45:5233-8. doi:10.1016/j.polymer.2004.05.018.

[21] Tămăşan M, Radu T, Simon V. Spectroscopic characterisation and in vitro behaviour of kaolinite polyvinyl alcohol nanocomposite. Appl Clay Sci 2013;72:147-54. doi:10.1016/j.clay.2012.11.009.

[22] Sirousazar M, Kokabi M, Bahramian AR, Hassan ZM. PVA/kaolinite nanocomposite hydrogels: Preparation method and characterization. Adv Mater Res 2012;383-390:3854-7. doi:10.4028/www.scientific.net/AMR.383-390.3854.

[23] M S, M K, Z, M H. Mineral Kaolinite Clay for Preparation of Nanocomposite Hydrogels. J Appl Polym Sci 2011;125. doi:10.1002/app.

[24] Lu Z, Wu A, Ou X, Zhang S, Niu J, Ji S, et al. Enhanced antiaging and mechanical properties of polyamide 1010 by solhydrothermal synthetic titanium dioxide-coated kaolinite addition. J Alloys Compd 2017;693:381-8. doi:10.1016/j.jallcom.2016.09.099.
[25] Elbokl TA, Detellier C. Aluminosilicate nanohybrid materials. Intercalation of polystyrene in kaolinite. J Phys Chem Solids 2006;67:950-5. doi:10.1016/j.jpcs.2006.01.008.

[26] de Macêdo Neto JC, Botan R, Lona LMF, Neto JE, Pippo WA. Polystyrene/kaolinite nanocomposite synthesis and characterization via in situ emulsion polymerization. Polym Bull 2015;72:387-404. doi:10.1007/s00289-014-1282-3.

[27] Zhang B, Li Y, Pan X, Jia X, Wang X. Intercalation of acrylic acid and sodium acrylate into kaolinite and their in situ polymerization. J Phys Chem Solids 2007;68:135-42. doi:10.1016/j.jpcs.2006.09.020.

[28] Chi Q, Zhen R, Wang X, Yang K, Jiang Y, Li F, et al. The role of exfoliated kaolinite on crystallinity, ion conductivity, thermal and mechanical properties of poly(ethylene oxide)/kaolinite composites. Polym Bull 2017;74:3089-108. doi:10.1007/s00289-016-1884-z.

[29] Zheng H, Feng X, Zhou L, Ye Y, Chen J. Intercalated polyaniline - kaolinite nanocomposite prepared via in situ mechanochemical synthesis 2016;43551:1-8. doi:10.1002/app.43551.

[30] Zhang X, Halim M, Ismail S, Ahmadun FB, Abdullah H, Hee C. Applied Clay Science Novel kaolinite based coolant for hyperthermal pyrotechnic aerosol cooling 2017;136:152-7. doi:10.1016/j.clay.2016.11.019.

[31] Su L, Zeng X, He H, Tao Q, Komarneni S. Applied Clay Science Preparation of functionalized kaolinite / epoxy resin nanocomposites with enhanced thermal properties. Appl Clay Sci 2017;148:103-8. doi:10.1016/j.clay.2017.08.017.

[32] Zhang Y, Liu Q, Zhang S, Zhang Y, Zhang Y, Liang P. Applied Clay Science Characterization of kaolinite / styrene butadiene rubber composite: Mechanical properties and thermal stability. Appl Clay Sci 2016;124-125:167-74. doi:10.1016/j.clay.2016.02.002.

[33] Jia D, Liu LAN, Wang X, Guo B. Advances in Natural Rubber / Montmorillonite Nanocomposites 2009:415-33.

[34] Xing D, He G, Hou Z, Ming P, Song S. Preparation and characterization of a modified montmorillonite / sulfonated polyphenylether sulfone / PTFE composite membrane. Int J Hydrogen Energy 2010;36:2177-83. doi:10.1016/j.ijhydene.2010.11.022.

[35] Al-shemmari FHJ, Rabah AA, Al-mulla EAJ, Osman N, Abd M. latex / modified montmorillonite clay nano-composite 2013:4293-301. doi:10.1007/s11164-012-0946-6.

[36] Zhang Y, Liu Y, Liu J, Guo P, Heng L. RSC Advances Super water absorbency OMMT / PAA hydrogel materials with excellent mechanical properties. RSC Adv 2017;7:14504-10. doi:10.1039/C7RA00372B.

[37] Kausar a. Exploration of novel heat and flame-resistant poly(urethane-imide)/functional layered silicate-based foams. High Perform Polym 2014;27:122-31. doi:10.1177/0954008314540926.

[38] Allison PG, Moser RD, Chandler MQ, Rivera OG, Goodwin JR, Gore ER, et al. Mechanical, Thermal, and Microstructural 
Analysis of Polyvinyl Alcohol / Montmorillonite Nanocomposites 2015;2015.

[39] Salahuddin N, Elbarbary A, Allam NG, Hashim AF. Polyamide-montmorillonite nanocomposites as a drug delivery system: Preparation, release of 1,3,4-oxa(thia)diazoles, and antimicrobial activity. J Appl Polym Sci 2014;41177:1-14. doi:10.1002/app.41177.

[40] Faghihi K, Abootalebi AS, Shabanian M. New clay-reinforced polyamide nanocomposite based on 4-phenylenediacrylic acid: Synthesis and properties. J Saudi Chem Soc 2013;17:191-7. doi:10.1016/j.jscs.2011.03.007.

[41] Huang W, Zeng S, Liu J, Sun L. Bi-axially oriented polystyrene/montmorillonite nanocomposite films. RSC Adv 2015;5:58191-8. doi:10.1039/C5RA09598K.

[42] Mrah L, Megabar R, Belbachir M. In-situ polymerization of styrene to produce polystyrene / montmorillonite nanocomposites. Bull Chem React Eng Catal 2015;10:249-55. doi:10.9767/bcrec.10.3.8708.249-255.

[43] Karakehya N, Bilgiç C. Inverse gas chromatographic determination of the surface energy of PMMA and PMMA / organophilic montmorillonite nanocomposites 2016:519-21. doi:10.1002/sia.5969.

[44] Banovac I, Perinovi S. Thermochimica Acta Preparation and characterization of melt intercalated poly ( ethylene oxide )/ lithium montmorillonite nanocomposites 2014;579:86-92. doi:10.1016/j.tca.2014.01.024.

[45] Thyagaraj T, Soujanya D. Applied Clay Science Polypropylene fi ber reinforced bentonite for waste containment barriers. Appl Clay Sci 2017;142:153-62. doi:10.1016/j.clay.2017.02.009.

[46] Lugão AB, Parra DF, Diaz FRV. MECHANICAL PROPERTIES OF POLYPROPYLENE PAPER 2015:659-66.

[47] Mondal D, Mollick MR, Bhowmick B, Maity D, Bain MK, Rana D, et al. Progress in Natural Science: Materials International Effect of poly ( vinyl pyrrolidone ) on the morphology and physical properties of poly ( vinyl alcohol )/ sodium montmorillonite nanocomposite fi $1 \mathrm{~ms}$. Prog Nat Sci Mater Int 2013;23:579-87. doi:10.1016/j.pnsc.2013.11.009.

[48] Simona C, Raluca I, Anita-laura R, Andrei S, Raluca S, Bogdan T, et al. Applied Clay Science Synthesis, characterization and ef fi ciency of new organically modi fi ed montmorillonite polyethersulfone membranes for removal of zinc ions from wastewasters. Appl Clay Sci 2017;137:135-42. doi:10.1016/j.clay.2016.12.013.

[49] Ghaemi N, Madaeni SS, Alizadeh A, Rajabi H, Daraei P. Preparation , characterization and performance of polyethersulfone / organically modified montmorillonite nanocomposite membranes in removal of pesticides. J Memb Sci 2011;382:135-47. doi:10.1016/j.memsci.2011.08.004.

[50] Garc C, Fittipaldi M, Grace LR. Epoxy / montmorillonite nanocomposites for improving aircraft radome longevity 2015;42691:1-9. doi:10.1002/app.42691.

[51] Yang C, Dingyang Y, Huawei Z, Mei L. RSC Advances Enhancing damping properties of epoxy resins using silicone macromolecule intercalated. RSC Adv 2014;4:44750-6. doi:10.1039/C4RA06329E.

[52] Yang MS, Ko SW, Park BJ, Okamoto S, Okamoto S, Choi HJIN. Fabrication and Thermal Characteristics of Liquid Crystalline Copolyester / OMMT Nanocomposite Films Fabrication and Thermal Characteristics of Liquid Crystalline Copolyester / OMMT Nanocomposite Films 2011;2348. doi:10.1080/00222341003784709.

[53] Nanocomposites SBR, Chakraborty S, Mallick PP, Dasgupta S. Stearyl Amine Ethoxylate ( SAM ) Grafted Montmorillonite Clay-Styrene Butadiene Rubber Stearyl Amine Ethoxylate ( SAM ) Grafted Montmorillonite Clay-Styrene Butadiene Rubber ( SBR ) Nanocomposites 2013;4037. doi:10.1080/00914037.2011.641649.

[54] Jurkowska B, Jurkowski B, Oczkowski M, Pesetskii SS, Koval V, Olkhov YA. Properties of Montmorillonite-Containing Natural Rubber 2007. doi:10.1002/app.

[55] Valadares LF, Leite CAP, Galembeck F. Preparation of natural rubber - montmorillonite nanocomposite in aqueous medium : evidence for polymer - platelet adhesion 2006;47:672-8. doi:10.1016/j.polymer.2005.11.062.

[56] Maria HJ, Lyczko N, Nzihou A, Joseph K, Mathew C, Thomas S. Applied Clay Science Stress relaxation behavior of organically modi fi ed montmorillonite fi lled natural rubber / nitrile rubber nanocomposites. Appl Clay Sci 2014;87:120-8. doi:10.1016/j.clay.2013.10.019.

[57] Intan N, Ismail N, Ansarifar MA, Song M. Improving Heat Ageing and Thermal Properties of Silicone Rubber Using Montmorillonite Clay 2014;41061:1-13. doi:10.1002/app.41061.

[58] Zhen R, Chi Q, Wang X, Yang K, Jiang YS, Li FF, et al. Crystallinity, ion conductivity, and thermal and mechanical properties of poly(ethylene oxide)-illite nanocomposites with exfoliated illite as a filler. J Appl Polym Sci 2016;133. doi:10.1002/app.44226.

[59] Wang A, Wang Y, Wang W, Shi X. A superabsorbent nanocomposite based on sodium alginate and illite/smectite mixed-layer clay. J Appl Polym Sci 2013;130:161-7. doi:10.1002/app.39141.

[60] Zhen R, Chi Q, Wang X, Yang K, Jiang Y, Li F, et al. Crystallinity, ion conductivity, and thermal and mechanical properties of poly ( ethylene oxide )- illite nanocomposites with exfoliated illite as a filler 2016;44226:1-10. doi:10.1002/app.44226.

[61] Kim J, Jeong E. Direct fluorination as a novel organophilic modification method for the preparation of Illite / polypropylene nanocomposites 2012:1046-53. doi:10.1007/s10853-011-5893-x.

[62] Li Y, Chen G, Guo S, Li H. Effect of Ultrasonic Oscillations on the Rheological Behavior and Morphology of Illite-Filled High-Density Polyethylene Composites 2004:4-9. doi:10.1002/app.21440.

[63] Shi J, Yu Z, Chen B, Zheng J. Preparation and Mechanical 
Properties of Composites Based on Rigid Polyvinyl Chloride Filled with Organic Modified Illite Powder Preparation and Mechanical Properties of Composites Based on Rigid Polyvinyl Chloride Filled with Organic Modified Illite Powd 2015;2348. doi:10.1080/00222348.2015.1019480.

[64] Srivastava N, Singh Y, Singh RA. Preparation of intercalated polyaniline / clay nanocomposite and its exfoliation exhibiting dendritic structure 2011;34:635-8.

[65] Jeong E, Won J, Seo K, Lee Y. Journal of Industrial and Engineering Chemistry Effects of physicochemical treatments of illite on the thermo-mechanical properties and thermal stability of illite / epoxy composites. J Ind Eng Chem 2011;17:77-82. doi:10.1016/j.jiec.2010.10.012.

[66] Materials AS. Eco-friendly Polymer Nanocomposites. vol. 74. 2015. doi:10.1007/978-81-322-2473-0.

[67] Kausar A. Review on Polymer/Halloysite Nanotube Nanocomposite. Polym Plast Technol Eng 2017;2559:03602559.2017.1329436.

doi:10.1080/03602559.2017.1329436.

[68] Azmi S, Razak SIA, Abdul Kadir MR, Iqbal N, Hassan R, Nayan NHM, et al. Reinforcement of poly(vinyl alcohol) hydrogel with halloysite nanotubes as potential biomedical materials. Soft Mater 2017;15:45-54. doi:10.1080/1539445X.2016.1242500.

[69] Ghanbari M, Emadzadeh D, Lau WJ, Matsuura T, Ismail AF. RSC Advances Synthesis and characterization of novel thin fi $1 \mathrm{~m}$ nanocomposite reverse osmosis membranes with improved organic fouling properties for water desalination. RSC Adv 2015;5:21268-76. doi:10.1039/C4RA16177G.

[70] Nicholson JC, Mills DK. Effect of barium-coated halloysite nanotube addition on the cytocompatibility, mechanical and contrast properties of poly ( methyl methacrylate ) cement 2017:105-14.

[71] Liu C, Luo YF, Jia ZX, Zhong BC, Li SQ, Guo BC, et al. Enhancement of mechanical properties of poly ( vinyl chloride ) with polymethyl methacrylate-grafted halloysite nanotube 2011;5:591-603. doi:10.3144/expresspolymlett.2011.58.

[72] Abdallah RM. Evaluation of polymethyl methacrylate resin mechanical properties with incorporated halloysite nanotubes 2016:167-71.

[73] Gradzik B, Stenzel A, Boccaccini AR, El M. Influence of functionalized halloysite clays ( HNT ) on selected properties of multiblock ( e ) PBS-EG copolymer obtained by enzymatic catalysis. Des Monomers Polym 2015;5551:1-11. doi:10.1080/15685551.2015.1041080.

[74] Zhao Q, Liu C, Liu J, Zhang Y. Development of a novel polyethersulfone ultrafiltration membrane with antibacterial activity and high flux containing halloysite nanotubes loaded with lysozyme. RSC Adv 2015;5:38646-53. doi:10.1039/C5RA05062F.

[75] Zhou T, Zhao Y, Han W, Xie H, Li C, Yuan M. Enhanced solvent-free selective oxidation of cyclohexene to 1,2cyclohexanediol by polyaniline@halloysite nanotubes. J Mater
Chem A Mater Energy Sustain 2017;5:18230-41. doi:10.1039/C7TA02605F.

[76] El-gawady YMH, Al-maadeed MASA. Halloysite Nanotube as Multifunctional Component in Epoxy Protective Coating 2016:11186-92. doi:10.1021/acs.iecr.6b02736.

[77] Saif MJ, Asif M, Naveed M, Zia KM, Zaman W, Khosa MK, et al. Halloysite reinforced epoxy composites with improved mechanical properties 2016;18:133-5.

[78] Vahedi V, Pasbakhsh P, Chai S. Toward high performance epoxy / halloysite nanocomposites: New insights based on rheological , curing, and impact properties. J Mater 2015;68:42-53. doi:10.1016/j.matdes.2014.12.010.

[79] Lin J, Zhong B, Jia Z, Hu D, Ding Y, Luo Y, et al. Applied Surface Science In-situ fabrication of halloysite nanotubes / silica nano hybrid and its application in unsaturated polyester resin. Appl Surf Sci 2017;407:130-6. doi:10.1016/j.apsusc.2017.02.149.

[80] Zhong B, Jia Z, Luo Y, Guo B, Jia D. Composites: Part A Preparation of halloysite nanotubes supported 2mercaptobenzimidazole and its application in natural rubber. Compos PART A 2015;73:63-71. doi:10.1016/j.compositesa.2015.03.007.

[81] Ismail H, Tan BK, Suharty NS, Husseinsyah S, Supri AG. Effects of Halloysite Nanotubes on the Properties of Polypropylene /( Recycled Natural Rubber Gloves )/( Halloysite Nanotubes Composites ) 2016:3-7. doi:10.1002/vnl.

[82] Guo Y, Chang CC, Cuiffo MA, Xue Y, Zuo X, Pack S, et al. Engineering flame retardant biodegradable polymer nanocomposites and their application in 3D printing. Polym Degrad Stab 2017;137:205-15. doi:10.1016/j.polymdegradstab.2017.01.019.

[83] Olivato JB, Marini J, Yamashita F, Pollet E, Grossmann MVE, Avérous L. Sepiolite as a promising nanoclay for nanobiocomposites based on starch and biodegradable polyester. Mater Sci Eng C 2017;70:296-302. doi:10.1016/j.msec.2016.08.077.

[84] Olad A, Zebhi H, Salari D, Mirmohseni A, Reyhanitabar A. A promising porous polymer-nanoclay hydrogel nanocomposite as water reservoir material: synthesis and kinetic study. J Porous Mater 2017;0:1-11. doi:10.1007/s10934-017-0479-x.

[85] Zhu M, Lan J, Tan C, Sui G, Yang X. Degradable cellulose acetate/poly- $<$ scp $>1</$ scp $>$-lactic acid/halloysite nanotube composite nanofiber membranes with outstanding performance for gel polymer electrolytes. J Mater Chem A 2016;4:1213643. doi:10.1039/C6TA05207J.

[86] Therias S, Murariu M, Dubois P. Bionanocomposites based on PLA and halloysite nanotubes: From key properties to photooxidative degradation. Polym Degrad Stab 2017;145:609. doi:10.1016/j.polymdegradstab.2017.06.008.

[87] Chiu FC. Halloysite nanotube- and organoclay-filled biodegradable poly(butylene succinate-co-adipate)/maleated polyethylene blend-based nanocomposites with enhanced rigidity. Compos Part B Eng 2017;110:193-203. 
doi:10.1016/j.compositesb.2016.10.091.

[88] Gaaz TS, Kadhum AAH, Kiah P, Michael A, Al-amiery AA, Sulong $\mathrm{AB}$, et al. Unique Halloysite Nanotubes - Polyvinyl Alcohol - Polyvinylpyrrolidone Composite Complemented with Physico - Chemical Characterization 2017. doi:10.3390/polym9060207.

[89] Saharudin MS, Wei J, Shyha I, Inam F. Biodegradation of halloysite nanotubes-polyester nanocomposites exposed to short term seawater immersion. Polymers (Basel) 2017;9. doi:10.3390/polym9080314.

[90] Kausar A. Advances in Polymer/Fullerene Nanocomposite: A Review on Essential Features and Applications. Polym - Plast Technol Eng 2017;56:594-605. doi:10.1080/03602559.2016.1233278.

[91] Dobashi R, Matsunaga K, Tajima M. Effects of fullerene derivatives on the gas permeability of thermoplastic polyurethane elastomers. J Appl Polym Sci 2014;131:1-6. doi:10.1002/app.39986.

[92] Kalin M, Zalaznik M, Novak S. Wear and friction behaviour of poly-ether-ether-ketone (PEEK) filled with graphene, WS2 and CNT nanoparticles. Wear 2015;332-333:855-62. doi:10.1016/j.wear.2014.12.036.

[93] Zhang M, Wang X, Bai Y, Li Z, Cheng B. C60 as fine fillers to improve poly(phenylene sulfide) electrical conductivity and mechanical property. Sci Rep 2017;7:4443. doi:10.1038/s41598-017-04491-1.

[94] Meng Z-Y, Chen L, Zhong H-Y, Yang R, Liu X-F, Wang Y-Z. Effect of different dimensional carbon nanoparticles on the shape memory behavior of thermotropic liquid crystalline polymer. Compos Sci Technol 2017;138:8-14. doi:10.1016/j.compscitech.2016.11.006.

[95] Rabarison RH, Valensi F, Diaham S, Razafinimanana M, Baltas M. Enhancement of Electrical Insulation Properties of Epoxy Nanocomposites with Fullerenes 2016:0-1.

[96] Al-Hartomy OA, Al-Ghamdi AA, Al-Salamy F, Dishovsky N, Slavcheva D, Iliev V, et al. Dielectric and microwave properties of fullerenes containing natural rubber-based nanocomposites. Fullerenes Nanotub Carbon Nanostructures 2014;22:332-45. doi:10.1080/1536383X.2012.684189.

[97] Adewunmi AA, Ismail S, Sultan AS. Carbon Nanotubes (CNTs) Nanocomposite Hydrogels Developed for Various Applications: A Critical Review. J Inorg Organomet Polym Mater 2016;26:717-37. doi:10.1007/s10904-016-0379-6.

[98] Wijewardane S. Potential applicability of CNT and CNT/composites to implement ASEC concept: A review article. Sol Energy 2009;83:1379-89. doi:10.1016/j.solener.2009.03.001.

[99] Memarian F, Fereidoon A, Ghorbanzadeh Ahangari M. The shape memory, and the mechanical and thermal properties of TPU/ABS/CNT: a ternary polymer composite. RSC Adv 2016;6:101038-47. doi:10.1039/C6RA23087C.

[100] Takizawa Y, Inukai S, Araki T, Cruz-Silva R, Uemura N, Morelos-Gomez A, et al. Antiorganic Fouling and Low-Protein
Adhesion on Reverse-Osmosis Membranes Made of Carbon Nanotubes and Polyamide Nanocomposite. ACS Appl Mater Interfaces 2017:acsami.7b06420. doi:10.1021/acsami.7b06420.

[101] Doagou-Rad S, Islam A, Jensen JS. Correlation of mechanical and electrical properties with processing variables in MWCNT reinforced thermoplastic nanocomposites. J Compos Mater 2018:0021998318768390. doi:10.1177/0021998318768390.

[102] Doagou-Rad S, Islam A, Jensen JS. Influence of Processing Conditions on the Mechanical Behavior of MWCNT Reinforced Thermoplastic Nanocomposites. Procedia CIRP 2017;66:131-6.

doi:https://doi.org/10.1016/j.procir.2017.03.362.

[103] Molla-Abbasi P, Ghaffarian SR. Decoration of carbon nanotubes by chitosan in a nanohybrid conductive polymer composite for detection of polar vapours. RSC Adv 2014;4:30906. doi:10.1039/C4RA04197F.

[104] Arrigo R, Morici E, Dintcheva NT. High performance thermoplastic elastomers/carbon nanotubes nanocomposites: Mechanical behavior, rheology, and durability. Polym Compos 2015. doi:10.1002/pc.23835.

[105] Ghoshal S, Wang P-H, Gulgunje P, Verghese N, Kumar S. High impact strength polypropylene containing carbon nanotubes. Polymer (Guildf) 2016;100:259-74. doi:10.1016/j.polymer.2016.07.069.

[106] Asif M, Tan Y, Pan L, Rashad M, Li J, Fu X, et al. Synthesis of a highly efficient 3D graphene-CNT-MnO 2 -PANI nanocomposite as a binder free electrode material for supercapacitors. Phys Chem Chem Phys 2016;18:26854-64. doi:10.1039/C6CP04996F.

[107] Barkoula NM, Alcock B, Cabrera NO, Peijs T. Fatigue properties of highly oriented polypropylene tapes and allpolypropylene composites. Polym Polym Compos 2008;16:101-13. doi:10.1002/pc.

[108] Ayatollahi MR, Doagou-Rad S, Shadlou S. Nano-/microscale investigation of tribological and mechanical properties of epoxy/MWNT nanocomposites. Macromol Mater Eng 2012;297:689-701. doi:10.1002/mame.201100271.

[109] Natarajan TS, Eshwaran SB, Stöckelhuber KW, Wießner S, Pötschke P, Heinrich G, et al. Strong Strain Sensing Performance of Natural Rubber Nanocomposites. ACS Appl Mater Interfaces 2017;9:4860-72. doi:10.1021/acsami.6b13074.

[110] Cho M-Y, Kim J-S, Lee H-G, Choi S-B, Kim G-W. A styrenebutadiene rubber (SBR)/carbon nanotube-based smart force sensor for automotive tire deformation monitoring 2016:980207. doi:10.1117/12.2218514.

[111] Miculescu M, Thakur VK, Miculescu F, Voicu SI. Graphenebased polymer nanocomposite membranes: a review. Polym Adv Technol 2016;27:844-59. doi:10.1002/pat.3751.

[112] Zhang J, Azam MS, Shi C, Huang J, Yan B, Liu Q, et al. Poly(acrylic acid) functionalized magnetic graphene oxide nanocomposite for removal of methylene blue. RSC Adv 2015;5:32272-82. doi:10.1039/C5RA01815C. 
[113] Mahendran R, Sridharan D, Santhakumar K, Selvakumar TA, Rajasekar P, Jang J. Nanocomposite Films with Antibacterial Properties 2016;2016.

[114] Safarpour M, Vatanpour V, Khataee A. Preparation and characterization of graphene oxide/TiO2 blended PES nanofiltration membrane with improved antifouling and separation performance. Desalination 2016;393:65-78. doi:10.1016/j.desal.2015.07.003.

[115] Akhina H, Gopinathan Nair MR, Kalarikkal N, Pramoda KP, Hui Ru T, Kailas L, et al. Plasticized PVC graphene nanocomposites: Morphology, mechanical, and dynamic mechanical properties. Polym Eng Sci 2017:1-10. doi:10.1002/pen.24711.

[116] Peña-Bahamonde J, San Miguel V, Nguyen HN, Ozisik R, Rodrigues DF, Cabanelas JC. Functionalization of reduced graphene oxide with polysulfone brushes enhance antibacterial properties and reduce human cytotoxicity. Carbon N Y 2017;111:258-68. doi:10.1016/j.carbon.2016.10.005.

[117] Alhumade H, Yu A, Elkamel A, Simon L, Abdala A. Enhanced protective properties and UV stability of epoxy/graphene nanocomposite coating on stainless steel. Express Polym Lett 2016;10:1034-46. doi:10.3144/expresspolymlett.2016.96.

[118] Pedrazzoli D, Dorigato A, Conti T, Vanzetti L, Bersani M, Pegoretti A. Liquid crystalline polymer nanocomposites reinforced with in-situ reduced graphene oxide. Express Polym Lett 2015;9:709-20. doi:10.3144/expresspolymlett.2015.66.

[119] Gaikwad G, Patil P, Patil D, Naik J. Synthesis and evaluation of gas sensing properties of PANI based graphene oxide nanocomposites. Mater Sci Eng B 2017;218:14-22. doi:10.1016/j.mseb.2017.01.008.

[120] Xue X, Yin Q, Jia H, Zhang X, Wen Y, Ji Q, et al. Enhancing mechanical and thermal properties of styrene-butadiene rubber/carboxylated acrylonitrile butadiene rubber blend by the usage of graphene oxide with diverse oxidation degrees. Appl Surf Sci 2017;423:584-91. doi:10.1016/j.apsusc.2017.06.200.

[121] Carbons OE, Bradley L. Viewpoint Innovating in carbon black 2016:18-21.

[122] Mohanapriya MK, Deshmukh K, Chidambaram K, Ahamed MB, Sadasivuni KK, Ponnamma D, et al. Polyvinyl alcohol (PVA)/polystyrene sulfonic acid (PSSA)/carbon black nanocomposite for flexible energy storage device applications. J Mater Sci Mater Electron 2017;28:6099-111. doi:10.1007/s10854-016-6287-2.

[123] Chatterjee T, Naskar K. Properties and Applications of Polymer Nanocomposites 2017:205-22. doi:10.1007/978-3662-53517-2.

[124] Sharma P, Panwar V, Pal K. Clay-Assisted dispersion of carbon black in thermoplastic nanocomposites. J Appl Polym Sci 2015;132:1-6. doi:10.1002/app.41477.

[125] Liang T, Yan C, Zhou S, Zhang Y, Yang B. Carbon black reinforced polymethyl methacrylate ( PMMA ) -based composite particles: preparation, characterization, and application 2017.
[126] Xue P, Wang J, Bao Y, Li Q, Wu C. Synergistic effect between carbon black nanoparticles and polyimide on refractive indices of polyimide/carbon black nanocomposites. New J Chem 2012;36:903. doi:10.1039/c2nj20869e.

[127] Liu Z, Li Z, Li D, Yin X, Liu Z. Use of manganese dioxide as oxidant in polymerization of aniline on carbon black for supercapacitor performance. High Perform Polym 2016;28:1105-13. doi:10.1177/0954008315620289.

[128] Xu P, Wang X, Hu Y, Ding Y. Piezoresistive properties of nanocomposites based on silicone rubber and ionic liquidfunctionalized carbon black. Mater Lett 2016;182:218-22. doi:10.1016/j.matlet.2016.06.097.

[129] Gang M, He G, Li Z, Cao K, Li Z, Yin Y, et al. Graphitic carbon nitride nanosheets/sulfonated poly(ether ether ketone) nanocomposite membrane for direct methanol fuel cell application. J Memb Sci 2016;507:1-11. doi:10.1016/j.memsci.2016.02.004.

[130] Shi Y, Fu L, Chen X, Guo J, Yang F, Wang J, et al. Hypophosphite/Graphitic Carbon Nitride Hybrids: Preparation and Flame-Retardant Application in Thermoplastic Polyurethane. Nanomaterials 2017;7:259. doi:10.3390/nano7090259.

[131] Shi Y, Yu B, Zhou K, Yuen RKK, Gui Z, Hu Y, et al. Novel $\mathrm{CuCo}<\inf >2</ \inf >\mathrm{O}<\inf >4</$ inf $>/$ graphitic carbon nitride nanohybrids: Highly effective catalysts for reducing $\mathrm{CO}$ generation and fire hazards of thermoplastic polyurethane nanocomposites. J Hazard Mater 2015;293:87-96. doi:10.1016/j.jhazmat.2015.03.041.

[132] Wang J, Li M, Zhou S, Xue A, Zhang Y, Zhao Y, et al. Graphitic carbon nitride nanosheets embedded in poly(vinyl alcohol) nanocomposite membranes for ethanol dehydration via pervaporation. Sep Purif Technol 2017;188:24-37. doi:10.1016/j.seppur.2017.07.008.

[133] Wang Y, Ou R, Wang H, Xu T. Graphene oxide modified graphitic carbon nitride as a modifier for thin film composite forward osmosis membrane. J Memb Sci 2015;475:281-9. doi:10.1016/j.memsci.2014.10.028.

[134] Zhang S, Zhao L, Zeng M, Li J, Xu J, Wang X. Hierarchical nanocomposites of polyaniline nanorods arrays on graphitic carbon nitride sheets with synergistic effect for photocatalysis. Catal Today 2014;224:114-21. doi:10.1016/j.cattod.2013.12.008.

[135] Liang Y, Liu DG, Bai WQ, Tu JP. Investigation of silicon carbon nitride nanocomposite films as a wear resistant layer in vitro and in vivo for joint replacement applications. Colloids Surfaces B Biointerfaces 2017;153:41-51. doi:10.1016/j.colsurfb.2017.02.010.

[136] Mochalin VN, Gogotsi Y. Nanodiamond-polymer composites. Diam Relat Mater 2015;58:161-71.

[137] Ayatollahi MR, Alishahi E, Doagou-R S, Shadlou S. Tribological and mechanical properties of low content nanodiamond/epoxy nanocomposites. Compos Part B Eng 2012;43. doi:10.1016/j.compositesb.2012.01.022. 
[138] Schrand AM, Johnson J, Dai L, Hussain SM, Schlager JJ, Zhu L, et al. Cytotoxicity and genotoxicity of carbon nanomaterials. Saf. Nanoparticles, Springer; 2009, p. 159-87.

[139] Salaam AD, Mishra M, Nyairo E, Dean D. Electrospun polyvinyl alcohol/nanodiamond composite scaffolds: morphological, structural, and biological analysis. J Biomater Tissue Eng 2014;4:173-80.

[140] Sun Y, Finne-Wistrand A, Waag T, Xing Z, Yassin M, Yamamoto A, et al. Reinforced degradable biocomposite by homogenously distributed functionalized nanodiamond particles. Macromol Mater Eng 2015;300:436-47.

[141] Goodwin DG, Boyer I, Devahif T, Gao C, Frank BP, Lu X, et al. Biodegradation of Carbon Nanotube/Polymer Nanocomposites using a Monoculture. Environ Sci Technol 2018;52:40-51. doi:10.1021/acs.est.7b02062.

[142] Gautam V, Singh KP, Yadav VL. Preparation and characterization of green-nano-composite material based on polyaniline, multiwalled carbon nano tubes and carboxymethyl cellulose: For electrochemical sensor applications. Carbohydr Polym 2018;189:218-28. doi:10.1016/j.carbpol.2018.02.029.

[143] Mandal B, Das D, Rameshbabu AP, Dhara S, Pal S. A biodegradable, biocompatible transdermal device derived from carboxymethyl cellulose and multi-walled carbon nanotubes for sustained release of diclofenac sodium. RSC Adv 2016;6:19605-11. doi:10.1039/C6RA00260A.

[144] Kuang T, Chang L, Chen F, Sheng Y, Fu D, Peng X. Facile preparation of lightweight high-strength biodegradable polymer/multi-walled carbon nanotubes nanocomposite foams for electromagnetic interference shielding. Carbon N Y 2016;105:305-13. doi:10.1016/j.carbon.2016.04.052.

[145] Fan J, Grande CD, Rodrigues DF. Biodegradation of graphene oxide-polymer nanocomposite films in wastewater. Environ Sci Nano 2017;4:1808-16. doi:10.1039/C7EN00396J.

[146] Chen F, Yang Q, Wang S, Yao F, Sun J, Wang Y, et al. Graphene oxide and carbon nitride nanosheets co-modified silver chromate nanoparticles with enhanced visible-light photoactivity and anti-photocorrosion properties towards multiple refractory pollutants degradation. Appl Catal B Environ 2017;209:493-505. doi:10.1016/j.apcatb.2017.03.026.

[147] Rouf TB, Kokini JL. Biodegradable biopolymer-graphene nanocomposites. J Mater Sci 2016;51:9915-45. doi:10.1007/s10853-016-0238-4.

[148] Yao J, Chen H, Jiang F, Jiao Z, Jin M. Titanium dioxide and cadmium sulfide co-sensitized graphitic carbon nitride nanosheets composite photocatalysts with superior performance in phenol degradation under visible-light irradiation. J Colloid Interface Sci 2017;490:154-62. doi:10.1016/j.jcis.2016.11.051.

[149] Stieven Montagna L, Amaral Montanheiro TL do, Chiodi Borges A, Yumi Koga-Ito C, Paula Lemes A, Cerqueira Rezende M. Biodegradation of PHBV/GNS nanocomposites by Penicillium funiculosum. J Appl Polym Sci 2017;134:1-8. doi:10.1002/app.44234.

[150] Asadi V, Jafari SH, Khonakdar HA, Häußler L, Wagenknecht
U. Incorporation of inorganic fullerene-like WS 2 into poly(ethylene succinate) to prepare novel biodegradable nanocomposites: a study on isothermal and dynamic crystallization. RSC Adv 2016;6:4925-35. doi:10.1039/C5RA24898A.

[151] Virovska D, Paneva D, Manolova N, Rashkov I, Karashanova D. Photocatalytic self-cleaning poly(l-lactide) materials based on a hybrid between nanosized zinc oxide and expanded graphite or fullerene. Mater Sci Eng C 2016;60:184-94. doi:10.1016/j.msec.2015.11.029.

[152] Agrawal R, Nieto A, Chen H, Mora M, Agarwal A. Nanoscale Damping Characteristics of Boron Nitride Nanotubes and Carbon Nanotubes Reinforced Polymer Composites. ACS Appl Mater Interfaces 2013;5:12052-7. doi:10.1021/am4038678.

[153] Zeng X, Deng L, Yao Y, Sun R, Xu J, Wong C-P. Flexible dielectric papers based on biodegradable cellulose nanofibers and carbon nanotubes for dielectric energy storage. J Mater Chem C 2016;4:6037-44. doi:10.1039/C6TC01501H.

[154] Wu L-P, You M, Wang D, Peng G, Wang Z, Chen G-Q. Fabrication of carbon nanotube (CNT)/poly(3hydroxybutyrate-co-3-hydroxyhexanoate) (PHBHHx) nanocomposite films for human mesenchymal stem cell (hMSC) differentiation. Polym Chem 2013;4:4490 doi:10.1039/c3py00668a.

[155] Kashi S, Gupta RK, Baum T, Kao N, Bhattacharya SN. Dielectric properties and electromagnetic interference shielding effectiveness of graphene-based biodegradable nanocomposites. Mater Des 2016;109:68-78. doi:10.1016/j.matdes.2016.07.062.

[156] Li C, Adamcik J, Mezzenga R. Biodegradable nanocomposites of amyloid fibrils and graphene with shape-memory and enzyme-sensing properties. Nat Nanotechnol 2012;7:421-7. doi:10.1038/nnano.2012.62.

[157] Kumar S, Raj S, Jain S, Chatterjee K. Multifunctional biodegradable polymer nanocomposite incorporating graphenesilver hybrid for biomedical applications. Mater Des 2016;108:319-32. doi:10.1016/j.matdes.2016.06.107.

[158] Pandiselvi K, Fang H, Huang X, Wang J, Xu X, Li T. Constructing a novel carbon nitride/polyaniline/ZnO ternary heterostructure with enhanced photocatalytic performance using exfoliated carbon nitride nanosheets as supports. J Hazard Mater 2016;314:67-77. doi:10.1016/j.jhazmat.2016.04.035.

[159] Wu X, Lu C, Zhang X, Zhou Z. Conductive natural rubber/carbon black nanocomposites via cellulose nanowhisker templated assembly: tailored hierarchical structure leading to synergistic property enhancements. J Mater Chem A 2015;3:13317-23. doi:10.1039/C5TA02601F.

[160] Ge F, Wang X, Ran X. Properties of biodegradable poly(butylene succinate) (PBS) composites with carbon black. Polym Sci Ser A 2017;59:416-24. doi:10.1134/S0965545X17030051.

[161] Liu H, Bai D, Bai H, Zhang Q, Fu Q. Manipulating the Filler 
Network Structure and Properties of Polylactide/Carbon Black Nanocomposites with the Aid of Stereocomplex Crystallites. J Phys Chem C 2018;122:4232-40. doi:10.1021/acs.jpcc.8b00417.

[162] Vijayakumar V, Khastgir D. Hybrid composite membranes of chitosan/sulfonated polyaniline/silica as polymer electrolyte membrane for fuel cells. Carbohydr Polym 2018;179:152-63. doi:10.1016/j.carbpol.2017.09.083.

[163] Yu Z, Li B, Chu J, Zhang P. Silica in situ enhanced PVA/chitosan biodegradable films for food packages. Carbohydr Polym 2018;184:214-20. doi:10.1016/j.carbpol.2017.12.043.

[164] Bao Z, Tao J, Flanigan C. The Combination of Montmorillonite and Silica in Styrene - Butadiene Rubber / Polybutadiene Rubber Tread Compounds 2017. doi:10.1002/pc.

[165] Zhang Q, Jiang J, Gao F, Zhang G, Zhan X, Chen F. Engineering high-effective antifouling polyether sulfone membrane with P(PEG-PDMS-KH570)@SiO2 nanocomposite via in-situ sol-gel process. Chem Eng J 2017;321:412-23. doi:10.1016/j.cej.2017.03.105.

[166] Tamburaci S, Tihminlioglu F. Diatomite reinforced chitosan composite membrane as potential scaffold for guided bone regeneration. Mater Sci Eng C 2017;80:222-31. doi:10.1016/j.msec.2017.05.069.

[167] Keller L, Regiel-Futyra A, Gimeno M, Eap S, Mendoza G, Andreu V, et al. Chitosan-based nanocomposites for the repair of bone defects. Nanomedicine Nanotechnology, Biol Med 2017;13:2231-40. doi:10.1016/j.nano.2017.06.007.

[168] Castillo-Dali G, Castillo-Oyague R, Batista-Cruzado A, LopezSantos C, Rodriguez-Gonzalez-Elipe A, Saffar J, et al. 'Reliability of new poly (lactic-co-glycolic acid) membranes treated with oxygen plasma plus silicon dioxide layers for preprosthetic guided bone regeneration processes.' Med Oral Patol Oral y Cir Bucal 2017;22:0-0. doi:10.4317/medoral.21512.

[169] Bian J, Wang ZJ, Lin HL, Zhou X, Xiao WQ, Zhao XW. Thermal and mechanical properties of polypropylene nanocomposites reinforced with nano-SiO2 functionalized graphene oxide. Compos Part A Appl Sci Manuf 2017;97:1207. doi:10.1016/j.compositesa.2017.01.002.

[170] Hasan SM, Thompson RS, Emery H, Nathan AL, Weems AC, Zhou F, et al. Modification of shape memory polymer foams using tungsten, aluminum oxide, and silicon dioxide nanoparticles. RSC Adv 2016;6:918-27. doi:10.1039/C5RA22633C.

[171] Chung JJ, Li S, Stevens MM, Georgiou TK, Jones JR. Tailoring Mechanical Properties of Sol-Gel Hybrids for Bone Regeneration through Polymer Structure. Chem Mater 2016;28:6127-35. doi:10.1021/acs.chemmater.6b01941.

[172] Liu P, Chen Y, Yu Z. Organic-inorganic hydrophobic nanocomposite film with a core-shell structure. Materials (Basel) 2016;9. doi:10.3390/ma9121021.

[173] Tangboriboon N, Samattai S, Kamonsawas J. Processing of Kaolinite and Alumina Loaded in Natural Rubber Composite
Foams Processing of Kaolinite and Alumina Loaded in Natural Rubber Composite Foams. LMMP 2015;30:595-604. doi:10.1080/10426914.2014.994768.

[174] Cai J, Zhang Y, Pan B, Zhang W, Lv L, Zhang Q. Efficient defluoridation of water using reusable nanocrystalline layered double hydroxides impregnated polystyrene anion exchanger. Water Res 2016;102:109-16. doi:10.1016/j.watres.2016.06.030.

[175] Nancy AC, Suthanthiraraj SA. Effect of Al 2 O 3 nanofiller on the electrical, thermal and structural properties of PEO : PPG based nanocomposite polymer electrolyte. Ionics (Kiel) 2017:1439-49. doi:10.1007/s11581-017-1976-2.

[176] Hoang AT, Nguyen QD, Wirges W, Gerhard R, Serdyuk Y V., Gubanski SM. Open-circuit thermally stimulated currents in LDPE/A12O3 nanocomposite. Annu Rep - Conf Electr Insul Dielectr Phenomena, CEIDP 2016;2016-Decem:611-4. doi:10.1109/CEIDP.2016.7785595.

[177] Liu D, Pallon LKH, Pourrahimi AM, Zhang P, Diaz A, Holler $\mathrm{M}$, et al. Cavitation in strained polyethylene/aluminium oxide nanocomposites. Eur Polym J 2017;87:255-65. doi:10.1016/j.eurpolymj.2016.12.021.

[178] Nho YC, Sohn JY, Shin J, Park JS, Lim YM, Kang PH. Preparation of nanocomposite ??-A12O3/polyethylene separator crosslinked by electron beam irradiation for lithium secondary battery. Radiat Phys Chem 2017;132:65-70. doi:10.1016/j.radphyschem.2016.12.002.

[179] Barkoula NM, Alcock B, Cabrera NO, Peijs T. Effective Methodology for the Production of Novel Nanocomposite Films Based on Poly(vinyl chloride) and Zinc Oxide Nanoparticles Modified With Green Poly(vinyl alcohol) Shadpour. Polym Polym Compos 2015;16:101-13. doi: $10.1002 / p c$.

[180] Hu Y, Du G, Chen N. A novel approach for Al2O3/epoxy composites with high strength and thermal conductivity. Compos Sci Technol 2016;124:36-43. doi:https://doi.org/10.1016/j.compscitech.2016.01.010.

[181] Yang D, Huang S, Ruan M, Li S, Yang J, Wu Y, et al. Mussel Inspired Modification for Aluminum Oxide/Silicone Elastomer Composites with Largely Improved Thermal Conductivity and Low Dielectric Constant. Ind Eng Chem Res 2018;57:3255-62. doi:10.1021/acs.iecr.7b04970.

[182] Al-Saygh A, Ponnamma D, AlMaadeed MAA, Poornima Vijayan P, Karim A, Hassan MK. Flexible pressure sensor based on PVDF nanocomposites containing reduced graphene oxide-titania hybrid nanolayers. Polymers (Basel) 2017;9:33. doi:10.3390/polym9020033.

[183] Meftahi A, Salehi F, Yadegari F, Alibakhshi S, Vatandoost S, Mohammadi H. ScienceDirect Finishing of Nylon/Cotton Fabric with $\mathrm{ZnO} / \mathrm{TiO} 2$ Nanocomposite. Procedia Mater Sci 2015;11:600-4. doi:10.1016/j.mspro.2015.11.088.

[184] Metanawin T, Jamjumrus A, Metanawin S. Morphology , Mechanical and Thermal Properties of PBT-TiO 2 Polymer Nanocomposite 2015;2:1-5. 
[185] Ni'Mah YL, Cheng MY, Cheng JH, Rick J, Hwang BJ. Solidstate polymer nanocomposite electrolyte of $\mathrm{TiO} 2 / \mathrm{PEO} / \mathrm{NaClO} 4$ for sodium ion batteries. J Power Sources 2015;278:375-81. doi:10.1016/j.jpowsour.2014.11.047.

[186] M. S, Natarajan K. Antibiofilm Activity of Epoxy/Ag-TiO2 Polymer Nanocomposite Coatings against Staphylococcus Aureus and Escherichia Coli. Coatings 2015;5:95-114. doi:10.3390/coatings5020095.

[187] Huang P, Shi H-Q, Xiao H-M, Li Y-Q, Hu N, Fu S-Y. High performance surface-modified $\mathrm{TiO} 2 /$ silicone nanocomposite. Sci Rep 2017;7:5951. doi:10.1038/s41598-017-05166-7.

[188] Zha J-W, Wang Y, Li W-K, Wang S-J, Dang Z-M. Electrical properties of polypropylene/styrene-ethylene-butylene-styrene block copolymer/MgO nanocomposites. IEEE Trans Dielectr Electr Insul 2017;24:1457-64. doi:10.1109/TDEI.2017.006162.

[189] Pallon LKH, Hoang AT, Pourrahimi AM, Hedenqvist MS, Nilsson F, Gubanski S, et al. The impact of $\mathrm{MgO}$ nanoparticle interface in ultra-insulating polyethylene nanocomposites for high voltage DC cables. J Mater Chem A 2016;4:8590-601. doi:10.1039/C6TA02041K.

[190] Čech Barabaszová K, Holešová S, Hundáková M, Pazdziora E, Ritz M. Antibacterial LDPE Nanocomposites Based on Zinc Oxide Nanoparticles/Vermiculite Nanofiller. J Inorg Organomet Polym Mater 2017;27:986-95. doi:10.1007/s10904-017-0546-4.

[191] Parvin MH, Pirnia M, Arjomandi J. Electrochemical synthesis, in situ spectroelectrochemistry of conducting indole-titanium dioxide and zinc oxide polymer nanocomposites for rechargeable batteries. Electrochim Acta 2015;185:276-87. doi:10.1016/j.electacta.2015.10.129.

[192] Shanthala VS, Shobha Devi SN, Murugendrappa MV. Synthesis, characterization and DC conductivity studies of polypyrrole/copper zinc iron oxide nanocomposites. J Asian Ceram Soc 2017;5:227-34. doi:10.1016/j.jascer.2017.02.005.

[193] Wagener P, Faramarzi S, Schwenke A, Rosenfeld R, Barcikowski S. Photoluminescent zinc oxide polymer nanocomposites fabricated using picosecond laser ablation in an organic solvent. Appl Surf Sci 2011;257:7231-7. doi:10.1016/j.apsusc.2011.03.097.

[194] Falah M, MacKenzie KJD, Knibbe R, Page SJ, Hanna J V. New composites of nanoparticle $\mathrm{Cu}$ (I) oxide and titania in a novel inorganic polymer (geopolymer) matrix for destruction of dyes and hazardous organic pollutants. J Hazard Mater 2016;318:772-82. doi:10.1016/j.jhazmat.2016.06.016.

[195] Khalid A, Khan R, Ul-Islam M, Khan T, Wahid F. Bacterial cellulose-zinc oxide nanocomposites as a novel dressing system for burn wounds. Carbohydr Polym 2017;164:214-21. doi:10.1016/j.carbpol.2017.01.061.

[196] Peng S, He J, Hu J, Huang X, Jiang P. Influence of functionalized $\mathrm{MgO}$ nanoparticles on electrical properties of polyethylene nanocomposites. IEEE Trans Dielectr Electr Insul 2015;22:1512-9. doi:10.1109/TDEI.2015.7116346.

[197] Hickey DJ, Ercan B, Sun L, Webster TJ. Adding MgO nanoparticles to hydroxyapatite-PLLA nanocomposites for improved bone tissue engineering applications. Acta Biomater 2015;14:175-84. doi:10.1016/j.actbio.2014.12.004.

[198] Guo Y, Du BX, Liu Y, Tian L. Tracking of Epoxy / MgO nanocomposites under DC Stress 2013:884-7.

[199] Diep VM, Armani AM. Flexible Light-Emitting Nanocomposite Based on ZnO Nanotetrapods. Nano Lett 2016;16:7389-93. doi:10.1021/acs.nanolett.6b02887.

[200] Patwary F, Matsko N, Mittal V. Biodegradation properties of melt processed $\mathrm{PBS} /$ chitosan bio-nanocomposites with silica, silicate, and thermally reduced graphene. Polym Compos 2018;39:386-97. doi:10.1002/pc.23947.

[201] Verma R, Singh S, Dalai MK, Saravanan M, Agrawal V V., Srivastava AK. Photocatalytic degradation of polypropylene film using TiO2-based nanomaterials under solar irradiation. Mater Des 2017;133:10-8. doi:10.1016/j.matdes.2017.07.042.

[202] Ando H, Kawasaki N, Yamano N, Uegaki K, Nakayama A. Biodegradation of a poly( $\varepsilon$-caprolactone-co-l-lactide)-visiblelight-sensitive TiO2composite with an on/off biodegradation function. Polym Degrad Stab 2015;114:65-71. doi:10.1016/j.polymdegradstab.2015.02.003.

[203] Saboktakin A, Saboktakin M. Improvements of physical, mechanical and biodegradation properties of polybutadiene rubber insulators by chitosan and silica nanoparticles. Int J Biol Macromol 2016;91:1194-8. doi:10.1016/j.ijbiomac.2016.06.078.

[204] Bendahou D, Bendahou A, Grohens Y, Kaddami H. New nanocomposite design from zeolite and poly(lactic acid). Ind Crops Prod 2015;72:107-18. doi:10.1016/j.indcrop.2014.12.055.

[205] Patra AS, Ghorai S, Sarkar D, Das R, Sarkar S, Pal S. Anionically functionalized guar gum embedded with silica nanoparticles: An efficient nanocomposite adsorbent for rapid adsorptive removal of toxic cationic dyes and metal ions. Bioresour Technol 2017;225:367-76. doi:10.1016/j.biortech.2016.11.093.

[206] Yang P, Zhu G, Xu S, Zhang X, Shen X, Cui X, et al. A novel shape memory poly( $\varepsilon$-caprolactone) network via UV-triggered thiol-ene reaction. J Polym Sci Part B Polym Phys 2017;55:692-701. doi:10.1002/polb.24314.

[207] Deshmukh K, Ahamed MB, Deshmukh RR, Pasha SKK, Sadasivuni KK, Polu AR, et al. Newly developed biodegradable polymer nanocomposites of cellulose acetate and Al2O3 nanoparticles with enhanced dielectric performance for embedded passive applications. J Mater Sci Mater Electron 2017;28:973-86. doi:10.1007/s10854-016-5616-9.

[208] Mohamed MA, Salleh WWN, Jaafar J, Ismail AF, Mutalib MA, Sani NAA, et al. Physicochemical characteristic of regenerated cellulose/ $\mathrm{N}$-doped $\mathrm{TiO} 2$ nanocomposite membrane fabricated from recycled newspaper with photocatalytic activity under UV and visible light irradiation. Chem Eng J 2016;284:202-15. doi:10.1016/j.cej.2015.08.128.

[209] Kotharangannagari VK, Krishnan K. Biodegradable hybrid 
nanocomposites of starch/lysine and $\mathrm{ZnO}$ nanoparticles with shape memory properties. Mater Des 2016;109:590-5. doi:10.1016/j.matdes.2016.07.046.

[210] Wojtal P, Luo D, Chen S, Zhitomirsky I. Composite PolymerMetal Hydroxide Coatings with Flame-Retardant Properties. Mater Manuf Process 2016;31:1201-5. doi:10.1080/10426914.2015.1037909.

[211] Goudarzi M, Ghanbari D, Salavati-niasari M. Room Temperature Preparation of Aluminum Hydroxide Nanoparticles and. J Nanostructures 2015;5:110-5. doi:10.7508/jns.2015.02.005.

[212] Yuan B, Zhang J, Yu J, Song R, Mi Q, He J, et al. Transparent and flame retardant cellulose/aluminum hydroxide nanocomposite aerogels. Sci China Chem 2016;59:1335-41. doi:10.1007/s11426-016-0188-0.

[213] Jiang H, Zhang G, Li F, Zhang Y, Lei Y, Xia Y, et al. Selfhealable and tough nanocomposite hydrogel crosslinked by novel ultrasmall aluminum hydroxide nanoparticles. Nanoscale 2017. doi:10.1039/C7NR04722C.

[214] Chen YA, Hang YT, Wu TM. Polymorphism and spherulite morphology of poly(1,4-butylene adipate)/organically-modified layered double hydroxide nanocomposites. J Appl Polym Sci 2015;132:1-7. doi:10.1002/app.42526.

[215] Haile M, Fomete S, Lopez ID, Grunlan JC. Aluminum hydroxide multilayer assembly capable of extinguishing flame on polyurethane foam. J Mater Sci 2015;51:375-81. doi:10.1007/s10853-015-9258-8.

[216] Attia NF, Goda ES, Nour MA, Sabaa MW, Hassan MA. Novel synthesis of magnesium hydroxide nanoparticles modified with organic phosphate and their effect on the flammability of acrylonitrile-butadiene styrene nanocomposites. Mater Chem Phys 2015;168:147-58. doi:10.1016/j.matchemphys.2015.11.014.

[217] Noh J, Kang I, Choi J, Fatima H, Yoo PJ, Oh KW, et al. Surface modification of magnesium hydroxide nanoparticles with hexylphosphoric acid to improve thermal stabilities of polyethylene composites. Polym Bull 2016;73:2855-66. doi:10.1007/s00289-016-1628-0.

[218] Jichun L, Yanbin Z, Zhuoli Y, Weiyuan Y, Jie L, Bingli P, et al. Enhancement of organoclay on thermal and flame retardant properties of polystyrene/magnesium hydroxide composite. Polym Compos 2014;37:746-55. doi:10.1002/pc.23231.

[219] Sugama T, Gawlik K. Nanoscale Boehmite Filler for Corrosion- and Wear-resistant Polyphenylenesulfide Coatings 2004;12:153-68.

[220] Karger-Kocsis J, Lendvai L. Polymer/boehmite nanocomposites: A review. J Appl Polym Sci 2017;45573:45573. doi:10.1002/app.45573.

[221] Mohammadnezhad G, Dinari M, Soltani R. The preparation of modified boehmite/PMMA nanocomposites by in situ polymerization and the assessment of their capability for $\mathrm{Cu}^{2+}$ ion removal. New J Chem 2016;40:3612-21. doi:10.1039/C5NJ03109E.
[222] Spiegel S. Recent advances in applied polymer science. J Appl Polym Sci 2018;135. doi:10.1002/app.46279.

[223] Agwuncha SC, Ray SS, Jayaramudu J, Khoathane C, Sadiku R. Influence of boehmite nanoparticle loading on the mechanical, thermal, and rheological properties of biodegradable polylactide/poly( $\varepsilon$-Caprolactone) blends. Macromol Mater Eng 2015;300:31-47. doi:10.1002/mame.201400212.

[224] Esposito Corcione C, Manno R, Frigione M. Sunlight curable boehmite/siloxane-modified methacrylic nano-composites: An innovative solution for the protection of carbonate stones. Prog Org Coatings 2016;97:222-32. doi:10.1016/j.porgcoat.2016.04.037.

[225] Inoue R, Kondo T, Kozako M, Hikita M. Effects of Tracking and Erosion Resistance of Nano-Boehmite Added Silicone Rubber 2017:4-6.

[226] Daud M, Kamal MS, Shehzad F, Al-Harthi MA. Graphene/layered double hydroxides nanocomposites: A review of recent progress in synthesis and applications. Carbon N Y 2016;104:241-52. doi:10.1016/j.carbon.2016.03.057.

[227] Tsai T-Y, Naveen B, Shiu W-C, Lu S-W. An advanced preparation and characterization of the PET/MgAl-LDH nanocomposites. RSC Adv 2014;4:25683-91. doi:10.1039/C4RA03171G.

[228] Rafiee F, Otadi M, Goodarzi V, Khonakdar HA, Jafari SH, Mardani E, et al. Thermal and dynamic mechanical properties of PP/EVA nanocomposites containing organo-modified layered double hydroxides. Compos Part B Eng 2016;103:12230. doi:10.1016/j.compositesb.2016.08.013.

[229] Zhao Y, Li N, Xia S. Polyamide nanofiltration membranes modified with $\mathrm{Zn}-\mathrm{Al}$ layered double hydroxides for natural organic matter removal. Compos Sci Technol 2016;132:84-92. doi:10.1016/j.compscitech.2016.06.016.

[230] Zhang R, Huang H, Yang W, Xiao X, Hu Y. Preparation and characterization of bio-nanocomposites based on poly(3hydroxybutyrate-co-4-hydroxybutyrate) and $\mathrm{CoAl}$ layered double hydroxide using melt intercalation. Compos Part A Appl Sci Manuf 2012;43:547-52. doi:10.1016/j.compositesa.2012.01.005.

[231] Totaro G, Sisti L, Celli A, Askanian H, Verney V, Leroux F. Poly(butylene succinate) bionanocomposites: a novel bioorgano-modified layered double hydroxide for superior mechanical properties. RSC Adv 2016;6:4780-91. doi:10.1039/C5RA24031J.

[232] Eili M, Shameli K, Ibrahim NA, Wan Yunus WMZ. Degradability enhancement of poly(lactic acid) by stearate$\mathrm{Zn}<\inf >3</$ inf $>$ Al LDH nanolayers. Int $J$ Mol Sci 2012;13:7938-51. doi:10.3390/ijms13077938.

[233] Guo W, Kang H, Chen Y, Guo B, Zhang L. Stronger and faster degradable biobased poly(propylene sebacate) as shape memory polymer by incorporating boehmite nanoplatelets. ACS Appl Mater Interfaces 2012;4:4006-14. doi:10.1021/am300828u.

[234] Gao C, Yu X-Y, Luo T, Jia Y, Sun B, Liu J-H, et al. 
Millimeter-sized $\mathrm{Mg}-\mathrm{Al}-\mathrm{LDH}$ nanoflake impregnated magnetic alginate beads (LDH-n-MABs): a novel bio-based sorbent for the removal of fluoride in water. $J$ Mater Chem A 2014;2:2119-28. doi:10.1039/C3TA13526H.

[235] Syamsundar C, Chatterjee D, Kamaraj M, Maiti AK. Erosion Characteristics of Nanoparticle-Reinforced Polyurethane Coatings on Stainless Steel Substrate. J Mater Eng Perform 2015;24:1391-405. doi:10.1007/s11665-015-1403-7.

[236] Mittal H, Maity A, Ray SS. Gum karaya based hydrogel nanocomposites for the effective removal of cationic dyes from aqueous solutions. Appl Surf Sci 2016;364:917-30. doi:10.1016/j.apsusc.2015.12.241.

[237] He J, Duffy NW, Pringle JM, Cheng YB. Conducting polymer and titanium carbide-based nanocomposites as efficient counter electrodes for dye-sensitized solar cells. Electrochim Acta 2013;105:275-81. doi:10.1016/j.electacta.2013.05.005.

[238] Ren Y, Zhu J, Wang L, Liu H, Liu Y, Wu W, et al. Synthesis of polyaniline nanoparticles deposited on two-dimensional titanium carbide for high-performance supercapacitors. Mater Lett 2018;214:84-7. doi:10.1016/j.matlet.2017.11.060.

[239] Wang P, Cheng L, Zhang L. One-dimensional carbon/SiC nanocomposites with tunable dielectric and broadband electromagnetic wave absorption properties. Carbon $\mathrm{N} \mathrm{Y}$ 2017;125:207-20. doi:10.1016/j.carbon.2017.09.052.

[240] Sarada K, Muraleedharan K. Thermal degradation and optical properties of SiC-infused polystyrene nanocomposites. J Therm Anal Calorim 2016;126:1809-19. doi:10.1007/s10973-0165709-y.

[241] Wang Y, Wang C, Xiao K. Investigation of the electrical properties of XLPE/SiC nanocomposites. Polym Test 2016;50:145-51. doi:10.1016/j.polymertesting.2016.01.007.

[242] M.K. Lee, J.K. Lee, G.J. Lee DMK. Effects of Ultrasonic Irradiation on Colloidal Stability of $\mathrm{B} 4 \mathrm{C}$ and $\mathrm{PbO}$ Particles and Preparations of Epoxy Composites. Polym Compos 2016. doi:10.1002/pc.

[243] Kiani MA, Ahmadi SJ, Outokesh M, Adeli R, Mohammadi A. Preparation and characteristics of epoxy/clay/B4C nanocomposite at high concentration of boron carbide for neutron shielding application. Radiat Phys Chem 2017;141:223-8. doi:10.1016/j.radphyschem.2017.07.013.

[244] Najim AS, Ola AK. Enhancement of Tribological and Mechanical Behavior of Polyphenylene Sulfide Reinforced by Titanium Dioxide Nanoparticles. Key Eng Mater 2016;724:207. doi:10.4028/www.scientific.net/KEM.724.20.

[245] Ling Weng, Qian-shan Xia, Li-wen Yan, Li-zhu Liu ZS. In Situ Preparation of Polyimide/Titanium Carbide Composites With Enhanced Dielectric Constant. Polym Compos 2016. doi:10.1002/pc.

[246] Weng YT, Pan HA, Wu NL, Chen GZ. Titanium carbide nanocube core induced interfacial growth of crystalline polypyrrole/polyvinyl alcohol lamellar shell for widetemperature range supercapacitors. J Power Sources 2015;274:1118-25. doi:10.1016/j.jpowsour.2014.10.158.
[247] Khan S, Ul-Islam M, Khattak WA, Ullah MW, Park JK. Bacterial cellulose-titanium dioxide nanocomposites: nanostructural characteristics, antibacterial mechanism, and biocompatibility. Cellulose 2015;22:565-79. doi:10.1007/s10570-014-0528-4.

[248] Weng Y-T, Wu N-L. Titanium carbide@polypyrrole core-shell nanoparticles prepared by controlled heterogeneous nucleation for rechargeable batteries. Chem Commun 2013;49:10784. doi:10.1039/c3ec43406k.

[249] Jin F-L, Zhang H, Yao S-S, Park S-J. Effect of Surface Modification on Impact Strength and Flexural Strength of Poly(lactic acid)/Silicon Carbide Nanocomposites. Macromol Res 2018;26:211-4. doi:10.1007/s13233-018-6028-x.

[250] Ching YC, Ershad Ali M, Abdullah LC, Choo KW, Kuan YC, Julaihi SJ, et al. Rheological properties of cellulose nanocrystal-embedded polymer composites: a review. Cellulose 2016;23:1011-30. doi:10.1007/s10570-016-0868-3.

[251] Orue A, Santamaria-Echart A, Eceiza A, Peña-Rodriguez C, Arbelaiz A. Office waste paper as cellulose nanocrystal source. J Appl Polym Sci 2017;134:1-11. doi:10.1002/app.45257.

[252] Dufresne A. Cellulose nanomaterials as green nanoreinforcements for polymer nanocomposites. Philos Trans R Soc A Math Phys Eng Sci 2018;376:20170040. doi:10.1098/rsta.2017.0040.

[253] Mahpeykar SM, Zhao Y, Li X, Yang Z, Xu Q, Lu ZH, et al. Cellulose Nanocrystal:Polymer Hybrid Optical Diffusers for Index-Matching-Free Light Management in Optoelectronic Devices. Adv Opt Mater 2017;5:1-7. doi:10.1002/adom.201700430.

[254] Song L, Wang Z, Lamm ME, Yuan L, Tang C. Supramolecular Polymer Nanocomposites Derived from Plant Oils and Cellulose Nanocrystals. Macromolecules 2017;50:7475-83. doi:10.1021/acs.macromol.7b01691.

[255] Nagalakshmaiah M, Pignon F, El Kissi N, Dufresne A. Surface adsorption of triblock copolymer (PEO-PPO-PEO) on cellulose nanocrystals and their melt extrusion with polyethylene. RSC Adv 2016;6:66224-32. doi:10.1039/C6RA11139D.

[256] Jain M, Pradhan MK. Morphology and mechanical properties of sisal fiber and nano cellulose green rubber composite: a comparative study. Int J Plast Technol 2016;20:378-400. doi:10.1007/s12588-016-9161-4.

[257] Mariano M, El Kissi N, Dufresne A. Cellulose nanocrystal reinforced oxidized natural rubber nanocomposites. Carbohydr Polym 2016;137:174-83. doi:10.1016/j.carbpol.2015.10.027.

[258] Feldman D. Lignin nanocomposites. J Macromol Sci Part A Pure Appl Chem 2016;53:382-7. doi:10.1080/10601325.2016.1166006.

[259] Roopan SM. An overview of natural renewable bio-polymer lignin towards nano and biotechnological applications. Int $\mathrm{J}$ Biol Macromol 2017;103:508-14. doi:10.1016/j.ijbiomac.2017.05.103.

[260] Jiang C, He H, Jiang H, Ma L, Jia DM. Nano-lignin filled 
natural rubber composites: Preparation and characterization. Express Polym Lett 2013;7:480-93. doi:10.3144/expresspolymlett.2013.44.

[261] Thakur S, Govender PP, Mamo MA, Tamulevicius S, Mishra YK, Thakur VK. Progress in lignin hydrogels and nanocomposites for water purification: Future perspectives. Vacuum 2017;146:342-55. doi:10.1016/j.vacuum.2017.08.011.

[262] Kouser R, Vashist A, Zafaryab M, Rizvi MA, Ahmad S. Biocompatible and mechanically robust nanocomposite hydrogels for potential applications in tissue engineering. $\begin{array}{llll}\text { Mater Sci Eng } & \text { C 2018;84:168-79. }\end{array}$ doi:10.1016/j.msec.2017.11.018.

[263] Palem RR, Saha N, Shimoga GD, Kronekova Z, Sláviková M, Saha P. Chitosan-silver nanocomposites: New functional biomaterial for health-care applications. Int J Polym Mater Polym Biomater 2018;67:1-10. doi:10.1080/00914037.2017.1291516.

[264] Bao Y, Zhang H, Luan Q, Zheng M, Tang H, Huang F. Fabrication of cellulose nanowhiskers reinforced chitosanxylan nanocomposite films with antibacterial and antioxidant activities. Carbohydr Polym 2018;184:66-73. doi:10.1016/j.carbpol.2017.12.051.

[265] Santos TC dos, Hernández R, Rescignano N, Boff L, Reginatto FH, Simões CMO, et al. Nanocomposite chitosan hydrogels based on PLGA nanoparticles as potential biomedical materials. Eur Polym J 2018;99:456-63. doi:10.1016/j.eurpolymj.2017.12.039.

[266] Abdeen ZI, El Farargy AF, Negm NA. Nanocomposite framework of chitosan/polyvinyl alcohol/ZnO: Preparation, characterization, swelling and antimicrobial evaluation. J Mol Liq 2018;250:335-43. doi:10.1016/j.molliq.2017.12.032.

[267] Poonguzhali R, Basha SK, Kumari VS. Nanostarch Reinforced with Chitosan/Poly (vinyl pyrrolidone) Blend for In Vitro Wound Healing Application. Polym - Plast Technol Eng 2017;0:1-11. doi:10.1080/03602559.2017.1381255.

[268] Sessini V, Arrieta MP, Fernández-torres A, Peponi L. Humidity-activated shape memory e ff ect on plasticized starch-based biomaterials 2018;179:93-9.

[269] Balakrishnan P, Gopi S, Thomas S. UV resistant transparent bionanocomposite films based on potato starch/cellulose for sustainable packaging $\dagger$. Starch/Stärke 2017;1700139:1-34. doi:10.1002/star.201700139.

[270] Feng Y, Zhang J, He J, Zhang J. Transparent cellulose/polyhedral oligomeric silsesquioxane nanocomposites with enhanced UV-shielding properties. Carbohydr Polym 2016;147:171-7. doi:10.1016/j.carbpol.2016.04.003.

[271] Qiu J, Xu S, Liu N, Wei K, Li L, Zheng S. Organic-inorganic polyimide nanocomposites containing a tetrafunctional polyhedral oligomeric silsesquioxane amine: synthesis, morphology and thermomechanical properties. Polym Int 2018;67:301-12. doi:10.1002/pi.5510.

[272] Yuasa S, Sato Y, Imoto H, Naka K. Fabrication of composite films with poly(methyl methacrylate) and incompletely condensed cage-silsesquioxane fillers. J Appl Polym Sci 2018;135:1-8. doi:10.1002/app.46033.

[273] Romo-Uribe A, Albanil L. Dynamics retardation in hybrid POSS-NIPAm nanocomposites. Thermoplastic and thermallyresponsive hydrogel behavior. Eur Polym J 2018;99:350-60. doi:10.1016/j.eurpolymj.2017.12.033.

[274] Beyth N, Houri-haddad Y, Domb A, Khan W, Hazan R. Alternative Antimicrobial Approach: Nano-Antimicrobial Materials 2015;2015. doi:10.1155/2015/246012.

[275] Yeh Y-C, Creran B, Rotello VM. Gold Nanoparticles: Preparation, Properties, and Applications in Bionanotechnology. Nanoscale 2012;4:1871-80 doi:10.1039/c1nr11188d.

[276] Wysokowski M, Materna K, Walter J, Petrenko I, Stelling AL, Bazhenov V V, et al. Solvothermal synthesis of hydrophobic chitin-polyhedral oligomeric silsesquioxane (POSS) nanocomposites. Int J Biol Macromol 2015;78:224-9.

[277] Suematsu K, Arimura M, Uchiyama N, Saita S. Transparent BaTiO3/PMMA Nanocomposite Films for Display Technologies: Facile Surface Modification Approach for BaTiO3 Nanoparticles. ACS Appl Nano Mater 2018. doi:10.1021/acsanm.8b00650.

[278] Caihong F, Lei S, Yihua Z, Jianfang W, Hongkai W. A Gold Nanocrystal/Poly(dimethylsiloxane) Composite for Plasmonic Heating on Microfluidic Chips. Adv Mater 2011;24:94-8. doi:10.1002/adma.201103517.

[279] Wei Z, Liu Y, Wang X, Yu J, Li F. Real-time tracking of the hierarchical structure of biodegradable poly(butylene succinateco-terephthalate) nanocomposites with fibrous attapulgite nanoparticles. Compos Sci Technol 2016;134:201-8. doi:10.1016/j.compscitech.2016.08.023.

[280] Sehgal RR, Carvalho E, Banerjee R. Mechanically Stiff, Zinc Cross-Linked Nanocomposite Scaffolds with Improved Osteostimulation and Antibacterial Properties. ACS Appl Mater Interfaces 2016;8:13735-47. doi:10.1021/acsami.6b02740.

[281] Xia B, Wang B, Shi J, Zhang Y, Zhang Q, Chen Z, et al. Photothermal and biodegradable polyaniline/porous silicon hybrid nanocomposites as drug carriers for combined chemophotothermal therapy of cancer. Acta Biomater 2017;51:197208. doi:10.1016/j.actbio.2017.01.015.

[282] Lalwani G, Henslee AM, Farshid B, Parmar P, Lin L, Qin YX, et al. Tungsten disulfide nanotubes reinforced biodegradable polymers for bone tissue engineering. Acta Biomater 2013;9:8365-73. doi:10.1016/j.actbio.2013.05.018.

[283] Nerantzaki M, Filippousi M, Van Tendeloo G, Terzopoulou Z, Bikiaris D, Goudouri OM, et al. Novel poly(butylene succinate) nanocomposites containing strontium hydroxyapatite nanorods with enhanced osteoconductivity for tissue engineering applications. Express Polym Lett 2015;9:773-89. doi:10.3144/expresspolymlett.2015.73.

[284] Austin HP, Allen MD, Donohoe BS, Rorrer NA, Kearns FL, Silveira RL, et al. Characterization and engineering of a plastic- 
degrading aromatic polyesterase. Proc Natl Acad Sci 2018:201718804. doi:10.1073/pnas.1718804115.

[285] Laycock B, Nikolić M, Colwell JM, Gauthier E, Halley P,
Bottle S, et al. Lifetime prediction of biodegradable polymers.

Prog

Polym

Sci

2017;71:144-89.

doi:10.1016/j.progpolymsci.2017.02.004. 